\title{
THE DANCING FLOOR OF WAR A study of Theban imperialism within Boeotia, ca. 525-386BCE
}

Alex Wilson

\author{
A thesis \\ submitted to Victoria University of Wellington \\ in fulfilment of the requirement for the degree of \\ Master of Arts in Classics
}

2013

School of Art History, Classics and Religious Studies 



\section{THE DANCING FLOOR OF WAR: A STUDY OF THEBAN IMPERIALISM WITHIN BOEOTIA, CA. 525-386BCE}

This thesis is a reexamination of Thebes' relationship with the neighbouring Greek poleis (city states) of Boeotia in early Greek history, including but not limited to the so-called Boeotian League or Confederation. Although it is generally acknowledged that Thebes was the dominant city of Boeotia in the Archaic and Classical Periods, scholarly opinion has varied on how to classify Thebes' dominance. At some point in the period considered here, the Boeotian states gathered themselves together into a regional collective, a confederation. The features of this union (in which Thebes was the leading participant) obscure Thebes' ambitions to subjugate other Boeotian states. I argue here that it is appropriate to define Thebes' relationship with Boeotia as imperialist.

I begin with a methodological consideration of the application of imperialism to ancient Greek history. The thesis considers in the first chapters three stages of development in Theban imperialism: firstly an early period (ca. 525) in which Thebes encouraged nascent Boeotian ethnic identity, promoting its own position as the natural leader of Boeotia. Secondly, a period (ca. 525-447) in which a military alliance of Boeotian states developed under the leadership of Thebes. Thirdly, a period which was the earliest true form of the Boeotian Confederation, contrary to scholarship which pushes the date of the Boeotian collective government back to the sixth century. I argue that the Boeotian federal constitution of 447-386 gave Thebes sufficient control of Boeotia to be classified as an imperialist structure.

A final chapter independently considers the evidence of Boeotian coinage, which has often been used problematically to inform historical analysis of Boeotian relations. I argue that on cultural and economic grounds alone the numismatic evidence suggests that Thebes' dominance in Boeotia extended to monetary influence. 



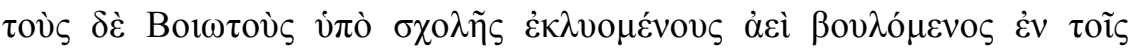

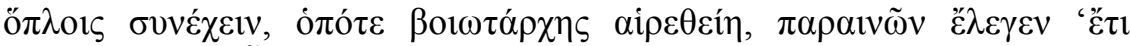

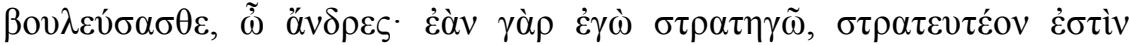

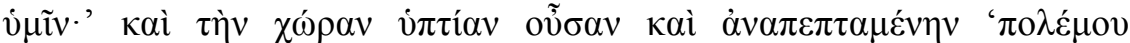

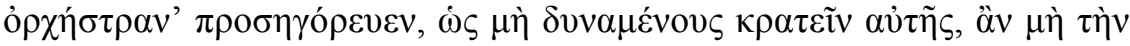

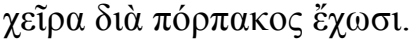

Wanting to keep in arms the Boeotians, who were growing dissolute with idleness, when Epameinondas was elected as their Boeotarch, he used to encourage them, saying: "Yet consider, gentlemen: if I am your general, you must be soldiers." He called the country, which was flat and open, "the dancing floor of war", because they could not rule it unless their hands were upon their shields. ([Plut.], On the Sayings of Kings and Commanders 193e) 



\section{ACKNOWLEDGEMENTS}

Many people have made this thesis better, directly or indirectly. I would like to thank the Classics Department of Victoria University, especially Dr Peter Gainsford and Dr Simon Perris, for an enormously valuable guided tour of Hesiodic epic, and Dr Judy Deuling, for her constant support and advice. Many stimulating conversations about ancient history with my fellow post-graduates, especially Daniel Diggins, Jason Morris, and Tania Hayes, are reflected in this discussion, and Chris de L'isle not only led by tremendous example but spent a great deal of his own time on reading and commenting on a draft, as did my father.

I am very grateful to my supervisor Dr Matthew Trundle, for his guidance and expertise.

My friends and workmates listened tolerantly to much more discussion of the Boeotians than they probably wished to.

Most of all, I would like to thank my parents and sister for their unfailing support,

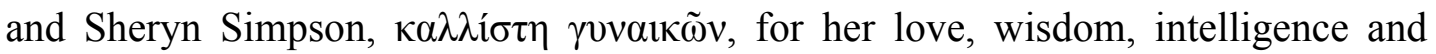
advice.

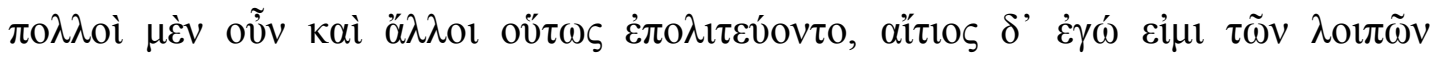
$\dot{\alpha} \mu \alpha \rho \tau i \tilde{\omega} v$. 


\section{TABLE OF CONTENTS}

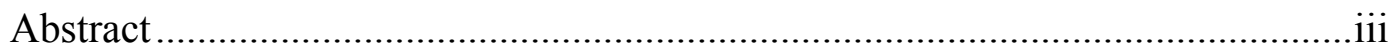

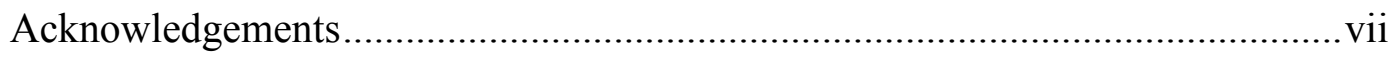

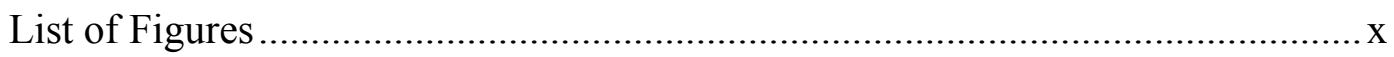

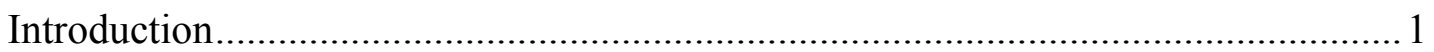

Imperialism in Ancient Greece .................................................................... 4

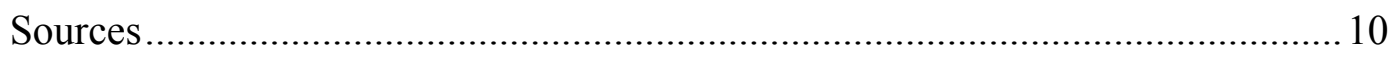

1 Boeotian Swine: Thebes and the Formation of Boeotian Ethnic Identity ............... 18

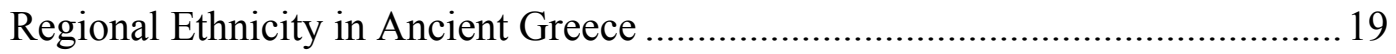

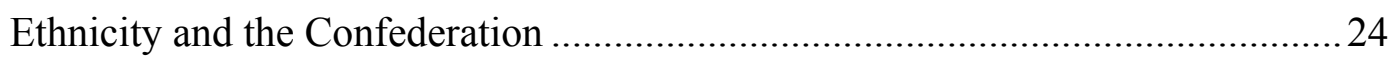

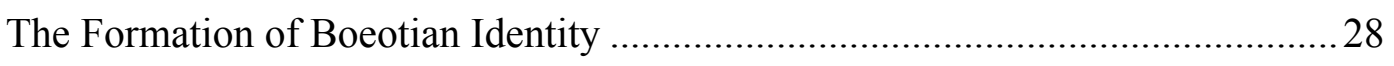

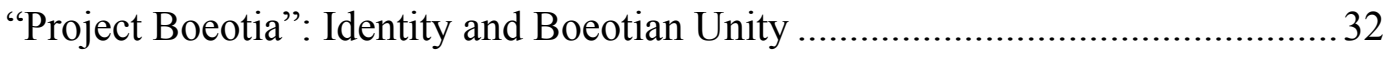

2 According to Ancient Custom: Theban Hegemony and Boeotian Symmachy ......49

Early Cooperative (and Uncooperative) Efforts ...............................................51

The Foundation of the Boeotian Confederation .............................................. 70

3 Poleis and Confederation: Thebes and the Boeotian Constitutions........................77

The Boeotian Confederate Constitution .......................................................... 78

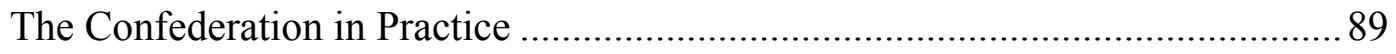

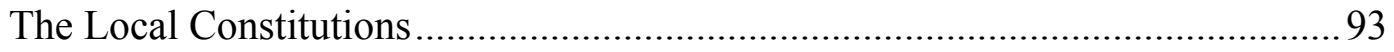

Thebes, Boeotia and the Peace of Antalcidas ....................................................... 94

4 Mad Heracles: Thebes and Boeotian Cooperative Coinage ................................ 104

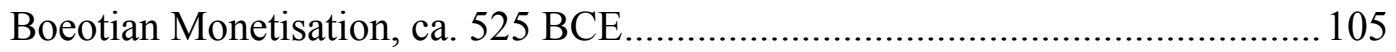

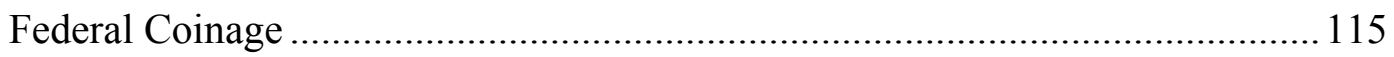

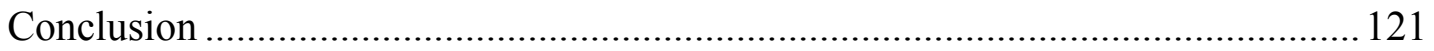

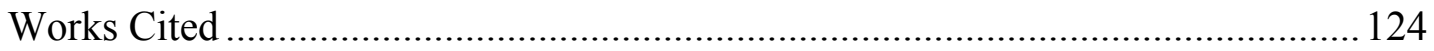




\section{LIST OF FIGURES}

Figure 1: The Boeotian League from the $6^{\text {th }}$ cent. to 146 BCE...............................

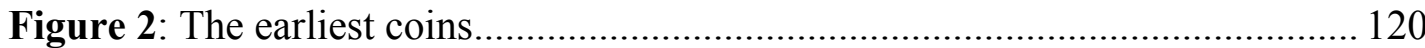

Figure 3: Theban coins, late fifth century? ..................................................... 120

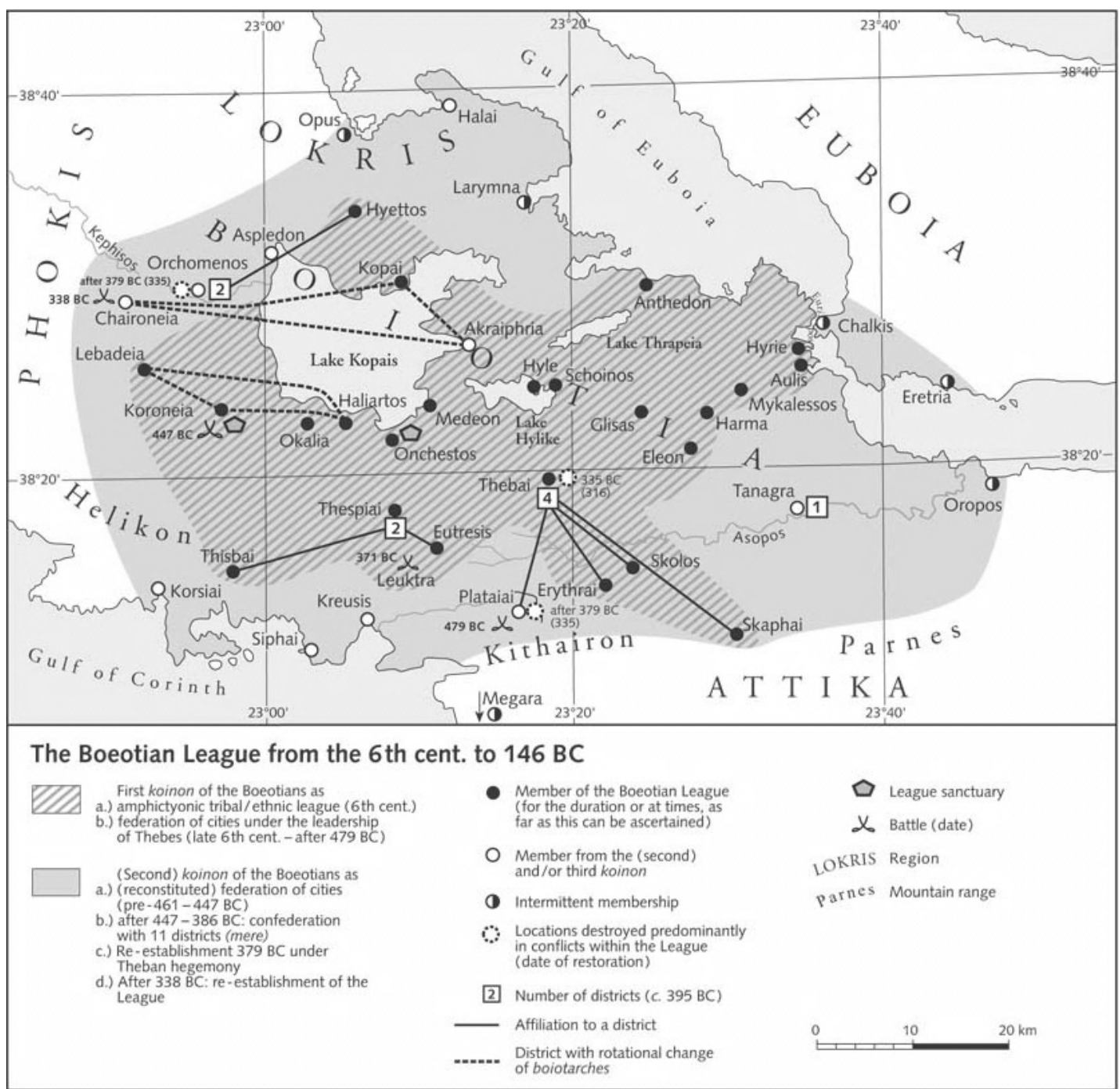

Figure 1: The Boeotian League from the $6^{\text {th }}$ cent. to $146 \mathrm{BCE}$.

From Funke, Peter (n.d.), "Boeotia, Boeotians", in Brill's New Pauly, edited by Hubert Cancik and Helmuth Schneider.

http://referenceworks.brillonline.com/entries/brill-s-new-pauly/boeotia-boeotians-e218930 


\section{NOTE ON TRANSLATION, SPELLING \& ABBREVIATIONS}

All translations in this thesis are my own. All dates are BCE unless otherwise stated. Throughout this thesis I have used as much as possible the traditional Anglicised and Romanised transcriptions of Greek names, based on the Thucydidean Attic forms (e.g. Ismenias and Plataea, not Hismenias and Plataiai), in the hopes that the benefits of readability will outweigh the loss of fidelity to the original. For Greek terms, however, I have been very faithful to the Greek and not translated any except the very familiar polis.

Abbreviations used are those of Simon Hornblower and Antony Spawforth eds., (2003) Oxford Classical Dictionary, third edition (Oxford: Oxford University Press), with these additions:

ACT Hornblower (1991-2008).

BNJ Worthington ed. (n.d.).

$C B \quad$ Schachter (1981-94).

$\mathrm{CH} \quad$ How and Wells (1912).

IGCH Thompson, Mørkholm and Kraay eds. (1973).

HCT Gomme, Andrewes, Dover (1945-81). 



\section{INTRODUCTION}

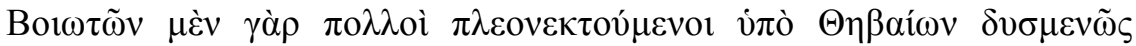

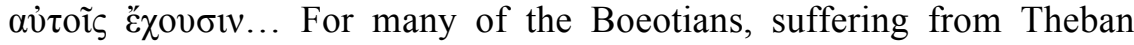
greed, dislike them. (Xen. Mem. 3.5.2)

At times the Boeotians were united in a league dominated by the Thebans, but such a league, in which force often had to be employed, was a far different and less effective means of achieving unity than the common Athenian citizenship. ${ }^{1}$

This thesis aims to demonstrate that Thebes dominated the other poleis in the Boeotian region from the late sixth century (ca. 525) until the development of a wider policy of Theban ambitions in the early fourth century. ${ }^{2}$ The regional politics of Boeotia consisted, in almost equal measures, of fractious disagreement and surprising cooperation between poleis; although it has been generally acknowledged that Thebes was a major player, the degree of aggression has been a point of some equivocation. In view of the formal structure of Boeotian cooperation (the so-called Boeotian League or Confederation), scholarship has tended to assume that disagreement was the exception to the cooperative norm. ${ }^{3}$ Fine's assessment, quoted above, is typical of the cautious tendency to see Thebes' domineering behaviour within Boeotia as an intermittent phenomenon. ${ }^{4}$ I examine the substance of Thebes' relationship with the Boeotians in order to determine the validity of this analysis.

This thesis explores the period from the beginnings of Boeotian interstate cooperation for military purposes (perhaps a $\sigma v \mu \mu \alpha \chi i \alpha$, "defensive and offensive alliance") in the late Archaic Period, the point which I identify as the beginning of Theban imperialism, to the imposition of the terms of the King's Peace on Boeotia in

\footnotetext{
${ }^{1}$ Fine (1983), 179.

${ }^{2}$ See Hansen (2004), esp. 437-459, on the other poleis of Boeotia.

${ }^{3}$ Throughout this thesis I use the term "cooperate" and its derivates as the broadest term for the variety of interactions involving more than one Boeotian state. I use this in a strictly literal and neutral sense, without the voluntary connotation which is often read into the word.

${ }^{4}$ Cf. Buckler (1980), 21; Buck (1994), 5; Buckley (1996), 238. Particularly telling is Bakhuizen (1994), 326, on the Classical Period as a whole: "Theban power ... was not an absolute leadership because of the full participation of all the Boeotians in voting and fighting". Contra: Bury (1959), 161; Morris and Powell (2006), 369: "[Thebes] had controlled the other cities in Boeotia since before 500 B.C."
} 
386. ${ }^{5}$ This was not the end of Theban imperialism. In fact, the so-called Theban hegemony began earlier in Boeotia (375-362) and was the acme of Theban power in Boeotia, and is thoroughly discussed, though generally as a separate phenomenon, by scholars such as Buckler. ${ }^{6}$ The overall aim of this thesis is to demonstrate that Thebes' imperialism in Boeotia was not a new phenomenon in the fourth century: Thebes had built an effective empire in progressive stages from the late sixth century.

This thesis is not concerned with cataloguing Thebes' relationships with individual

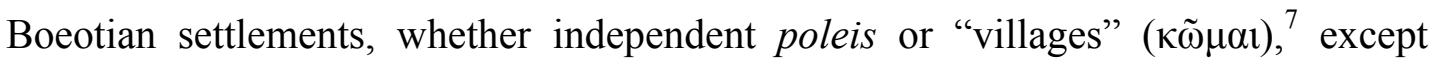
where that relationship may elucidate the more general attitude of Thebes towards Boeotia: as I will discuss in chapter one, Theban rhetoric even in conflict with individual poleis referred to the Boeotians as a whole. Thebes' interactions with its neighbours were frequently antagonistic. Moreover, there are a substantial number of Boeotian settlements for which there is no recorded act of subjugation but which nevertheless seem to have fallen under Theban control; in particular many settlements of eastern Boeotia, from Aulis to Anthedon, seem to have been Theban subordinates or satellites throughout the Archaic and Classical Period.

There is no focused discussion of Thebes' relationship with Boeotia. Buck and Cloché have treated the matter only incidentally to the history of one party or the other. ${ }^{8}$ Dull's little-read thesis considers (despite the promising title, "A Study of the Leadership of the Boeotian League from the Invasion of the Boiotoi to the King's Peace") largely the limited scope of the period 447-386, and limits itself to the discussion of leadership of the Boeotian Confederation. ${ }^{9}$ Two developments in scholarship in particular prompt reanalysis of the relationship between Thebes and Boeotia in the period considered here. Firstly, Schachter and Larsen have recently

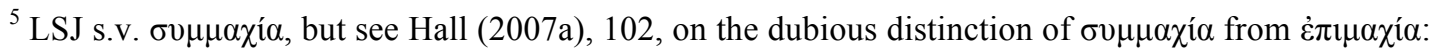
perhaps, in Thucydides' use at least, a solely defensive alliance.

${ }^{6}$ Buckler (1980) remains the standard account; see esp. 15-45 on the relationship with Boeotia; Larsen (1968), 175-78, and Beck (1997), discuss the Boeotian Confederation of the fourth century; Beister (1989), Thebes' hegemony, with particular comparison to Athens and Sparta; Bakhuizen (1994), 313-26, on Boeotia as Theban dependency.

${ }^{7}$ See Hansen and Nielsen (2004), 75-76, on the problems of the terms for "second-" and "thirdorder" sites.

${ }^{8}$ Buck (1979), (1994); Cloché (1952).

${ }^{9}$ Dull (1976).
} 
rejected the standing belief that federalism in Boeotia dates back to the sixth century. ${ }^{10}$ This trend does not, however, negate the evidence of interactions between the Boeotian states from the late Archaic Period onwards. Thebes is prominent in these sources, and I will reconsider these occurences as evidence of Thebes' imperialism. Secondly, it is by now widely recognised that the dating of the numismatic evidence for Boeotia in the Archaic and Classical Period is highly problematic, ${ }^{11}$ and should no longer be used to inform the historical situation of Boeotia (as in past scholarship) without extreme caution. ${ }^{12}$ Following the reevaluations of the chronology of Boeotian coinage problematises many analyses of Boeotian history. ${ }^{13}$

Boeotia was unusual amongst Greek regions in the Classical Period. Although it was divided into as many as twenty-six known poleis and about forty settlements in total, ${ }^{14}$ the strife attendant on close neighbours was accompanied by not only a degree of cultural and religious unity, but also a broader identity within Boeotia that cut across civic boundaries. ${ }^{15}$ The cooperation which resulted from this shared identity is often referred to as the Boeotian League or Confederation. ${ }^{16}$ This terminology, however, is modern; for the duration of the Archaic and Classical

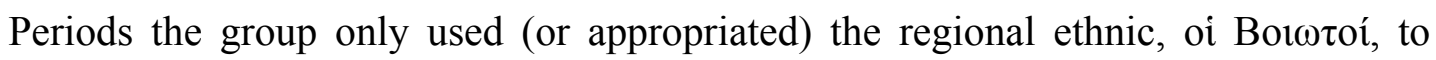
describe their unity. ${ }^{17}$ Moreover, modern analysis has created terminology for periodisation of Boeotian cooperation which is inconsistent and implies both a

\footnotetext{
${ }^{10} C B$ 2:216, Larson (2007).

${ }^{11}$ Buck (1994), xviii.

${ }^{12}$ Roesch (1981), 271.

${ }^{13}$ Hansen (2004), 432-33, gives a neat summary of these revisions and adds some of his own; unfortunately, these are not yet fully argued or systematic.

${ }^{14}$ See Hansen (1995b), 13-24, for the enumeration of Boeotian poleis from the archaic period to 386 ; Hansen (2004) takes a broader view and includes lesser settlements.

${ }^{15}$ Prevalent practice (especially in numismatics: J. Jones 1986, s.v. "ethnic") in discussing ancient Greek identity terms uses "ethnic" ( $\dot{\varepsilon} \theta v ı \kappa o ́ v)$ for the descriptive terms relating to the polis as well as

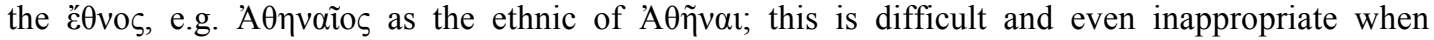
discussing both at the same time, as in the case of Boeotia (see Hansen and Nielsen [2004], 60-62). I will therefore generally use the terms "civic" for the polis-ethnic and "ethnic" for the "है $\theta$ vo -ethnic.

16 English scholarship tends to refer to the Boeotian "League", although League is imprecise, covering a variety of concepts from $\sigma 0 \mu \mu \alpha \chi i \alpha$ to Kovvóv; Mackil (2003), 1-4, argues that the most appropriate term for ancient Greek federalism is "Confederation", cf. Ehrenberg (1969), 112, on "leagues"; Salmon (1994), on terminology for Boeotia.

${ }^{17}$ Occasionally, scholars have appealed to some form of "slippage", i.e. that a source uses the ethnic but means the civic or vice versa. I will assume throughout this thesis that the distinction between

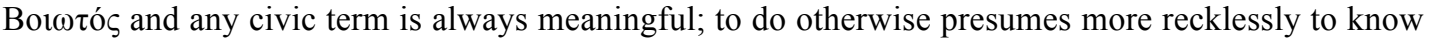
better than the source.
} 
structure and a development which the ancient Greeks did not themselves identify (see Table 1): I will therefore avoid terms such as the "first league", etc.

\begin{tabular}{|c|c|c|c|c|}
\hline Dates & (1) Salmon & (2) González & (3) Hansen & (4) Buck \\
\hline ca. $700-520$ & \multirow{2}{*}{$\begin{array}{l}\text { Union des } \\
\text { Béotiens }\end{array}$} & "Archaic period" & & \\
\hline ca. $520-479$ & & $\begin{array}{l}\text { First } \\
\text { Confederation } 1\end{array}$ & & \multirow[t]{2}{*}{$\begin{array}{l}\text { Early Boeotian } \\
\text { League }\end{array}$} \\
\hline $479-457$ & & $\begin{array}{l}\text { First } \\
\text { Confederation } 2\end{array}$ & & \\
\hline $457-447$ & & $\begin{array}{l}\text { First } \\
\text { Confederation } 3\end{array}$ & & $\begin{array}{l}\text { Boeotian League } \\
\text { (under Athenian } \\
\text { hegemony) }\end{array}$ \\
\hline $447 / 6-386$ & $\begin{array}{l}\text { Première } \\
\text { confédération }\end{array}$ & $\begin{array}{l}\text { First } \\
\text { Confederation } 4\end{array}$ & First Federation & Boeotian League \\
\hline \multicolumn{5}{|l|}{$386-379$} \\
\hline $379-338$ & $\begin{array}{l}\text { Ligue thébain } \\
\text { (état fédéral à } \\
\text { tendence } \\
\text { unitaire) }\end{array}$ & $\begin{array}{l}\text { Second } \\
\text { Confederation }\end{array}$ & $\begin{array}{l}\text { Second } \\
\text { Federation }\end{array}$ & $\begin{array}{l}\text { Boeotian League } \\
\text { restored }\end{array}$ \\
\hline $338-172$ & \multirow[t]{2}{*}{$\begin{array}{l}\text { Seconde } \\
\text { confédération }\end{array}$} & $\begin{array}{l}\text { Third } \\
\text { Confederacy }\end{array}$ & Third Federation & \\
\hline $172-146$ & & & & \\
\hline
\end{tabular}

Table 1. Terminology for periodisation of the so-called Boeotian Confederation in (1) Salmon (1994); (2) González (2006); (3) Hansen (2004); (4) Buck (1979) and (1994).

I begin with two considerations of methodological issues: firstly, a discussion of the application of imperialism studies to ancient Greek history and how to identify imperialist structures, followed by a discussion of the sources used in this thesis and the evidential issues with our historiographical sources for Boeotian history.

\section{IMPERIALISM IN ANCIENT GREECE}

This thesis uses imperialism as the lens for considering Thebes' position in the regional politics of Boeotia. In the following section I will discuss what exactly I mean by imperialism. "Imperialism" and the related noun "empire" are difficult terms to define, and largely modern concepts; however, it is possible to come to a broad definition or typology which can be applied to ancient states. 
Imperialism, a modern term, has often been approached as a tenuous optic for history, especially for the ancient world. ${ }^{18}$ What exactly constitutes imperialism is the subject of a great deal of critical debate. Thus, Cain and Harrison: "[imperialism is] an essentially contested concept"; ${ }^{19}$ Hobson: "amid the welter of vague political abstractions to lay one's finger accurately upon any 'ism' so as to pin it down and mark it out by definition seems impossible". ${ }^{20}$

Doyle defines empires thus: "Empires are relationships of political control imposed by some political societies over the effective sovereignty of other politics." ${ }^{21}$ This is not an exact definition but an exegesis. The breadth of scope in the explanation is noteworthy, although Doyle also argues that it is important to keep the relationship between empire and imperialism in mind, i.e. that imperialism is whatever leads to empire. ${ }^{22}$ Such a proviso would naturally severely limit an analysis of Theban imperialism, as Boeotia is not identified as truly subject to Thebes in any source until the period of the Theban hegemony. ${ }^{23}$ However, this proviso tends towards a circular definition. If both "empire" and "imperialism" are treated as unquantifiable, then imperialism leads to empire, but empire results from imperialism. Finley offers a useful rebuttal: "Missing opportunities, 'not playing the game well', hardly prove the absence of "ambitions'." 24 Many of the surviving instances of Theban imperialism which I will discuss in this thesis come to light due to the prominent intervention of external powers, in particular Athens and Sparta, with resulting failure of the Theban attempts to subordinate: so Thebes was frustrated at Plataea in

\footnotetext{
18 In particular, in post-colonial scholarship, imperialism is used as a dysphemism which is not necessarily applicable to the ancient view of empires: cf. Saïd $(1979,1993)$ on post-colonialism; Garnsey and Whittaker (1978b), 1-3, and Champion (2009), 87-90, on ancient-world applications.

${ }^{19}$ Cain and Harrison (2001), 3.

${ }^{20}$ Hobson (1902), 1.

${ }^{21}$ Doyle (1986), 19. See Reynolds (1981), 19-68, on the classical analysis of a relationship between "power" and "imperialism" through a search for security, and Davies (1994), 53-62, on the usefulness of "sovereignty" in the analysis of Greek history despite the lack of Greek vocabulary.

${ }^{22}$ Doyle (1986), 33, and 45: "Imperialism is simply the process or policy of establishing or maintaining an empire."

${ }^{23}$ Isoc. 14.9-11; Diod. 15.38.3-4, 15.50.2. See Larsen (1968), 177. The dichotomisation of the imperialist city ("metropole") and subjects ("frontier"/"periphery") is part of the process of empire: Ludden (2011), 135-36.

${ }^{24}$ Finley (1978a), 2.
} 
the sixth century and Orchomenus in the early fourth. ${ }^{25}$ In this thesis I will accept that empire is the desired result of imperialism, but that imperialism is a quantifiable attitude and need not be entirely successful. I will argue that Thebes' interactions with Boeotia fall within the imperialist spectrum of imposed political control, even if Boeotia was not overtly subject to Thebes until after the period discussed here.

The application of imperialism to the study of Greek history has frequently been limited to discussion of legal structures of imperial administration; that is, direct and formal control of the powerful state over the subordinate states. This was thus the underlying concern of Ferguson, the first dedicated study of Greek imperialism. ${ }^{26}$ The extraction of tribute from Delian League members by the Athenian state, instituted by a binding oath, is the only less contentious example of imperialism within the Greek world. ${ }^{27}$ I will argue that we cannot identify the existence of a legal structure to enforce Theban imperialism in Boeotia under after the Battle of Oenophyta (447). This did not preclude Thebes from controlling Boeotian affairs before then.

The Theban relationship with the rest of Boeotia is generally identified as "hegemonic". Doyle defines hegemony as a lesser degree of control between states, where the powerful state controls only the external affairs (foreign relations) of the subordinate states. ${ }^{28}$ In Greek history, hegemony ( $\left.\dot{\eta} \gamma \varepsilon \mu o v i ́ \alpha\right)$ is generally linked to military leadership. ${ }^{29}$ However, scholars have distinguished broadly between hegemony and empire ( $\dot{\alpha} \rho \chi \eta ́)$ in ancient Greece solely on moral perspective, and not

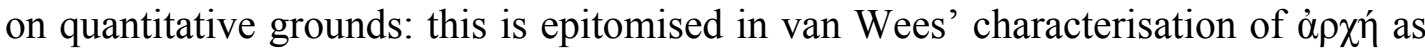

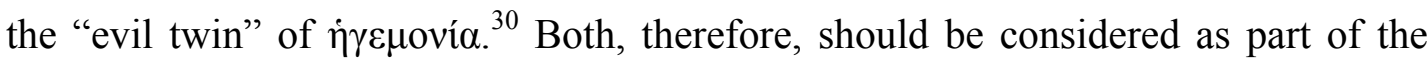
broad spectrum of imperialism. Hammond has suggested that the relationship between kindred states, such as Thebes and the rest of Boeotia, should also be

\footnotetext{
${ }^{25}$ Ferguson (1913) argued that imperialism could not be successful with in the state system of ancient Greece, and that Athens and Sparta both stumbled when they attempted to strengthen their hegemonies.

${ }^{26}$ Ferguson (1913). Ferguson himself argued (vii) that the Greek states did not lend themselves to becoming fully-formed empires, and therefore the scope of his investigation was largely limited to structures within the imperialist states.

${ }^{27}$ The classic study of the formal aspects of fifth-century Athenian imperialism is Meiggs (1972).

${ }^{28}$ Doyle (1986), 40.

${ }^{29}$ Wickersham (1994) is an invaluable analysis of hegemony in Greek historiography.

${ }^{30}$ Van Wees (2004), 8, summarising Wickersham (1994).
} 
excepted from the definitions of imperialism, ${ }^{31}$ but as I argue in chapter one, kinship is a matter of construction, and not of incontrovertible fact, as with Athens' purported ethnic relationship with the Ionians in the Delian League.

A formal, legal and deliberate policy of imperialism is inadequate to address all empires and imperialist attitudes: "Empire is a state of affairs even when the imperial power is not formally constituted as such". ${ }^{32}$ By way of comparison, such an approach has recently received broad acceptance in discussions of Republican Roman imperialism, especially in the eastern Mediterranean. ${ }^{33}$ Doyle for example has argued persuasively that maintaining a limited definition of territorial control not only ignores both current popular and scholarly use of the terms "imperialism" and "empire", but employs an inconsistent criterion, as the general assumption that territorial possession is coextensive with political control of that territory is not reliably borne out in practice. ${ }^{34}$ He defines instead "empire" as "effective control, whether formal or informal, of a subordinated society by an imperial society". ${ }^{35}$ It is this concept of effective control which I will apply to Thebes' relations with other Boeotian states.

Finley, acknowledging the need for a less restrictive approach to imperialism in ancient Greece, has set out an admittedly crude typology of empires, with six criteria for demonstrating "imperialism":

(1) restriction on freedom of action in inter-state relations;

(2) political, administrative and/or judicial interference in local affairs;

(3) compulsory military and/or naval service;

(4) the payment of 'tribute' in some form, whether in the narrow sense of a regular lump sum or as a land tax or in some other way;

(5) confiscation of land, with or without subsequent emigration of settlers from the imperial state;

\footnotetext{
${ }^{31}$ M. Hammond (1948), 108-9.

${ }^{32}$ Lichtheim (1971), 4.

${ }^{33}$ E.g. Gruen (1984); Eckstein (2006).

${ }^{34}$ Doyle (1986), 33.

${ }^{35}$ Doyle (1986), 30.
} 
(6) other forms of economic subordination or exploitation, ranging from control of the seas and Navigation Acts to compulsory delivery of goods at prices below the prevailing market price and the like. ${ }^{36}$

I will argue that all six criteria can be identified in Boeotia under Thebes, and that in particular criteria (1), (3), (5) and (6) were features of early Theban imperialism; while criteria (2) and (4) and were only exercised from the mid-fifth century onwards, under the auspices of the formal Boeotian Confederation. Most significant here, however, is the vocabulary of power: restriction, interference, compulsion, confiscation, subordination. The use of force, or the threat of force, as a form of persistent control of other states is the common factor in these criteria.

Finley's fourth criterion ("the payment of 'tribute' in some form") has been one of the most widely recognised indications of imperialism. ${ }^{37}$ In ancient Greek history, the extraction of tribute from the Delian League and Athenian moves to appropriate the resources of the League treasury are central to discussion of Athenian imperialism. ${ }^{38}$ However, the matter of tribute or tax in the Delian League was

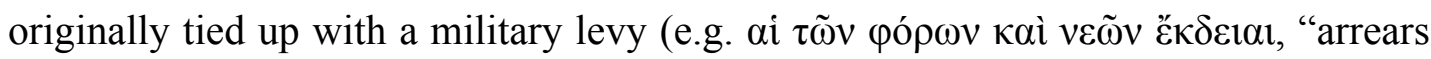
of tribute and ships", Thuc. 1.99.1). ${ }^{39}$ The shift to primarily monetary forms of tribute enhanced Athenian opportunities for exploitation, but the exploitation of League resources predated Athens' enforcement of the monetary pópos. Mandatory military contributions for the benefit of the metropole was also a form of economic exploitation. ${ }^{40}$ Thus, the third criterion ("compulsory military/naval service") should perhaps be considered as fulfilling in some part the fourth criterion; neither one should necessarily be singled out from the general economic exploitation of the sixth criterion. They are certainly not unrelated.

\footnotetext{
${ }^{36}$ Finley (1978b), $107 \approx$ Finley (1978a), 6, which gives consideration to Rome as well as Athens.

${ }^{37}$ E.g. Scheidel (2011), 194-96, on taxation in Rome and Han China. See the essays in Cain and Harrison (2001), 1:201-353, on the economic aspects of imperialism. The origins of imperialism studies in Marxism (such as Hobson [1902], the father of imperialism studies) may explain the focus on economic exploitation.

${ }^{38}$ See Meiggs (1972), 234-54 and Finley (1978b), 114-17, on Athenian tribute; Meiggs (1972), 25572 and Finley (1978b), 117-21, on other forms of economic extraction in the Athenian empire.

39 Foster (2010), esp. 34-43, argues that Thucydides' presentation of imperialism focuses on the material resources of both the imperial powers (Athens, and in the "Archaeology", Agamemnon and Minos) and of the periphery. On Thuc. 1.99.1, a famous explanation of why the Athenians came to imperialise the Delian League, she argues (111) that Thucydides places the blame on the allies for Athenian imperialism (contra de Romilly [1963], 91); a peripheral analysis of Athenian imperialism.

${ }^{40}$ See Weber (2001), 334, on Athenian profit from war.
} 
It is important to note that in Boeotian history effective control could be achieved on a personal level, through relationships between individual citizens in each state, and not solely through the imposition of control over the decision-making bodies of a state. Thebes was an oligarchy until $379,{ }^{41}$ and while the constitutions of the other Boeotian poleis are not always clear, they were certainly oligarchies between 447 and the Peace of Antalcidas (Hell. Oxy. 16.2). ${ }^{42}$ Power therefore rested in the hands of a smaller group of men who could organise policy across state borders. ${ }^{43}$ This was clearly the case in Boeotia in the early fourth century, as in the Hellenica Oxyrhynchia's description of the factions of Leontiades and Ismenias (17.2). ${ }^{44}$

Imperialism studies are generally an attitudinal analysis of foreign politics. As I will discuss below, ancient sources give little insight into Boeotian decision-making. It is very difficult therefore to demonstrate that Thebes adopted a particular policy, beginning in the late sixth century, of subordinating other Boeotian states. The few references to Theban politics are concerned with shifting blame, and highlight a high degree of factionalism and changing political ascendencies within Thebes (cf. Thuc. 3.63; Hell. Oxy. 17). ${ }^{45}$ Andrewes, like other scholars, has focused on a demonstrable policy as an essential factor in identifying imperialism. ${ }^{46} \mathrm{He}$ argues that the lack of cohesive and consistent policy means we cannot call Sparta imperialist. I reject this methodological concern; it is sufficient to demonstrate, in lines with Schumpeter's definition, "the object-less disposition of a state to expansion by force without assigned limits." 47

\footnotetext{
${ }^{41}$ A broad oligarchy until 382, and a very narrow oligarchy around the faction of Leontiades between 382 and 379 (Buck [1994], 69-7, calls it a tyranny); cf. Buckler (1980), 34-45, on the rise of the democracy at Thebes.

42 Buck (1994), 6.

${ }^{43}$ Examples of aristocrats drawing Thebes into local disputes abound, and constitute what Ludden (2011), 140, terms "imperial fission", whereby activists at the "frontier" (see p. 5 n. 23) involve the "metropole".

${ }^{44}$ Buck (1994), 12-14.

${ }^{45}$ Boeotia was almost proverbially factional, cf. Arist. Rhet. 1407a4-6; Thucydides' statement that "the same people inhabited Attica always due to the long-standing freedom from stasis due to the

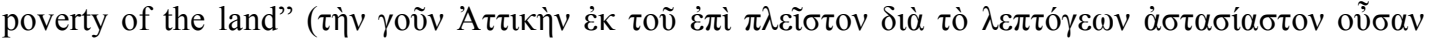

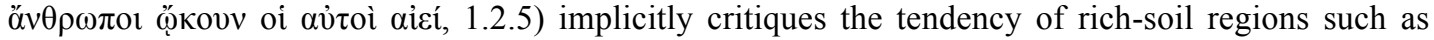
Boeotia to stasis; as Hornblower notes (ACT 1:12), this is strictly a non-sequitur. Thucydides presents poor land as a benefit to Athenian power: Foster (2010), 14. Amit (1973), 69, argues that just because the Theban excuses of oligarchic domination in the Persian Wars were convenient does not mean they were not true.

${ }^{46}$ Andrewes (1978), cf. Harris (1979), on the Roman "war machine", critiqued in Raaflaub (1996).

${ }^{47}$ Schumpeter (1919), 6.
} 
As Champion notes, Finley's typology invites a search for specific examples to fulfil the criteria. ${ }^{48}$ In this thesis, then, I focus on discussing the recognisable acts of Theban imperialism, particularly following the six criteria identified by Finley. These, I will argue, bring together a clear view of effective imperialism: within the view of Schumpeter's long-standing definition, Thebes expanded its control over other states, although generally not its territory. In lieu of a demonstrable policy or attitude, I focus on the historical evidence for the forcible nature of relations between Thebes and Boeotia.

\section{SOURCES}

One of the goals of this thesis is to exercise caution with the sources available. This thesis relies largely on literary sources. There are no surviving epigraphic sources relating to the Boeotian Confederation before its fourth-century revival during the Theban hegemony. ${ }^{49}$ A very few inscriptions can be used to demonstrate aspects of Boeotian military cooperation in the Archaic period. The limitations of sources on Boeotian history in terms of quantity, chronological proximity, and personal bias, discussed in the following paragraphs, have resulted in a tendency to apply the available sources as widely as possible, sometimes overly so. ${ }^{50}$ In particular, chronologically scattered sources are used to fill in gaps in periods to which the sources did not originally apply: so the Hellenica Oxyrhynchia, discussing the federal constitution in 395, has been used explain the functions of the Boeotarchs mentioned by Herodotus during the Plataean campaign of 479, and Hellenistic attestation of the Pamboeotian Games has been drawn back to the Archaic Period. I will take the view that such synchronistic uses of evidence require a more compelling reason than simple silence of more appropriate sources, and especially so when there are clear indications that the sources are not applicable.

Due to the comparative paucity of surviving Boeotian sources, we are often in the dark on the internal history of Boeotia. ${ }^{51}$ Moreover, the Boeotian sources which do

\footnotetext{
${ }^{48}$ Champion (2009), 89.

${ }^{49}$ Rhodes and Lewis (1997), 122.

${ }^{50}$ Roesch (1981), 269-70.

51 Not, it would seem, for want of Boeotian authors writing about Boeotia, despite Athenian disparagement of Boeotian cultural achievements: the Boeotian historians Daemachus, Anaxis and
} 
survive (Hesiod, Pindar and Plutarch, most substantially) have particular problems as reliable sources for Boeotian history. All three were educated men who wrote in dialects other than Boeotian; in the cases of Hesiod and Pindar this reflects their Panhellenic poetic traditions. ${ }^{52}$ Although presumably their fellow Boeotian élites would not have been hindered in their enjoyment of Hesiod and Pindar's work by the epic and Doric dialects, ${ }^{53}$ the use of external dialects reflects engagement with external, not local, culture. Hesiod's Works and Days in particular uses Boeotia as the backdrop for a discussion contemporary issues, but is presented as a Panhellenic work and does little to acknowledge Boeotia. In the case of Pindar, we can observe how few of his surviving epinicia are written for Theban winners, though even these are written in Doric. Moreover, writing epic (albeit in a didactic mode) and epinician poetry, respectively, Hesiod and Pindar cannot be relied on for fidelity to any historic reality. ${ }^{54}$

Plutarch, like the much earlier Boeotians, wrote in a non-Boeotian dialect, but in his case this is indicative of the substantial period which stands between his time and the Classical Period and the archaicising preference given to Atticism among intellectuals of the high Roman Empire. However, Plutarch's bias towards his homeland is a reason for caution. ${ }^{55}$ For Plutarch, it seems, much of the internecine feuding of Boeotian states was no longer relevant, or less relevant in the broad Mediterranean scope of his scholarly interests. His patriotism encompassed at least Theban achievements, if not all of Boeotia: his lost Life of Epameinondas, paired with Scipio Africanus, was given pride of place as the opening piece; a hint is given by his characterisation of the Theban uprising against Spartan occupation of the Cadmea in the Pelopidas:

\footnotetext{
Dionysodorus each wrote a fourth-century Hellenica (see FGrH 65, 67, 68): see Tuplin (2007) on what might be expected in a Hellenica. Diodorus' statement (15.95.4) that Anaxis and Dionysodorus both finished with the end of Theban hegemony in 361 implies a valuable Boeotian perspective on the fourth century. Various works of regional history, Boeotica or Thebaica, are also attested: see FGrH 3:ch. XII on Boeotian historiography and Harding (2007) on regional histories.

${ }^{52}$ Pelliccia (2009), 241, refers to Pindar, Bacchylides and Simonides as "international poets". See West (1978), 26-27 and 31-32, on Hesiod's style of Ionic.

${ }^{53}$ Anson (2009), 9.

${ }^{54}$ West (1978), 22-25, on didactic genre and the Works and Days; Kurke (1991) on the Panhellenic market for epinicia.

${ }^{55}$ Pelling (2010), xv, summarises the point neatly.
} 


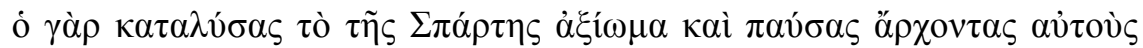

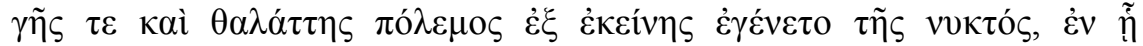

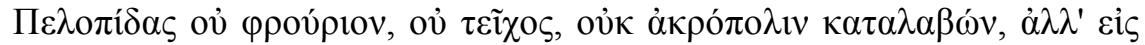

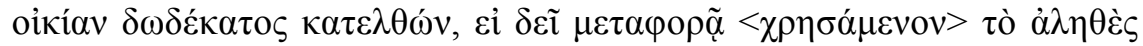

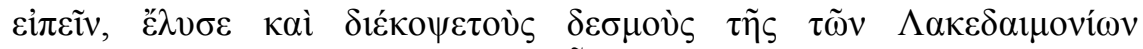

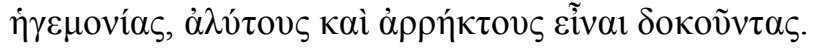

For the war which undid Sparta's pretensions and stopped the Spartans' rule on land and at sea began from that night, when Pelopidas, not by taking any garrison, barricade or citadel, but by coming into a house in a group of twelve, if the truth may be said by means of a metaphor, undid and shattered the fetters of Spartan hegemony, which seemed to be unloosenable and unbreakable. (13.7)

His characterisation falls neatly in line with the Theban propaganda about the uprising. He does provide a helpful voice on the fourth century by preserving accounts derived from contemporary sources other than Xenophon and the Hellenica Oxyrhynchia, at least some of which presents a Theban point of view. ${ }^{56}$ His sources do not seem to be much different from those available to other historians, ${ }^{57}$ but he sometimes includes apocryphal material which renders him unreliable when we cannot ascertain his source.

I will attempt nevertheless to use these internal sources to demonstrate cultural and discursive aspects of Theban imperialism where possible. For the most part, however, I must rely on texts intended for and written by non-Boeotians: Herodotus, Thucydides, Xenophon and the Hellenica Oxyrhynchia. Herodotus certainly used contemporary Boeotian sources, for a Boeotian is one of the two Greek sources sources named in the Histories: Thersander of Orchomenus, an eyewitness to a dinner for Thebans and Persians before the Battle of Plataea $(9.16) .{ }^{58} \mathrm{He}$ visited Thebes, where he saw "Cadmean letters" at the Temple of Ismenian Apollo (5.5961). On the other hand, Herodotus' tendency to seek out prominent figures (including Thersander) for his sources exposed him to the bias of invested sources; where these were Athenian the common anti-Boeotian sentiment may make its way into Herodotus' account. ${ }^{59}$ Thucydides' specific sources are generally impenetrable. While he claims to have had access to sources on the anti-Athenian side, he names

\footnotetext{
${ }^{56}$ Westlake (1985), 122.

${ }^{57}$ Westlake (1985), 122.

${ }^{58}$ Hornblower (2002), 374.

${ }^{59}$ See Bakhuizen (1989), 67-68, on ancient insults; Zeitlin (1989) on the more cerebral use of Thebes as "Other" in Attic drama; Cartledge (2000), 401, on the same discourse in modern scholarship.
} 
only Peloponnesians specifically (5.26). ${ }^{60}$ Spartans, along with the Plataean refugees at Athens, may have been his only sources for the Plataean campaign (431-27). Therefore, while both fifth-century historians did use some Boeotian sources, neither of them can be relied upon for a Theban point of view.

In using these texts, and particularly the work of the pro-Athenian and pro-Spartan authors which make up the bulk of the Classical historiographical corpus, it is important to keep in mind the Boeotian patriot Plutarch's admonition regarding the style of Greek historians, particularly Herodotus:

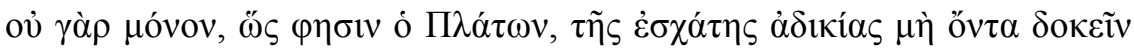

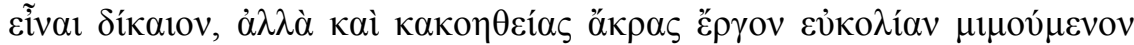

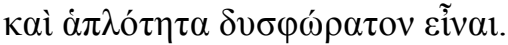

For it is not only, as Plato says, a most extreme injustice to seem fair without being so, but also the height of malignance to fake mildness and simplicity while being harsh. (De Hdt. mal. 854f)

Plutarch explicitly argues here for implicit biases in Herodotus which secretly attack his subjects rather than offering overt critique. He carries on to single out the Boeotians and Corinthians as the main victims ("most of all his malice is used

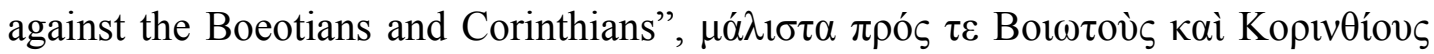

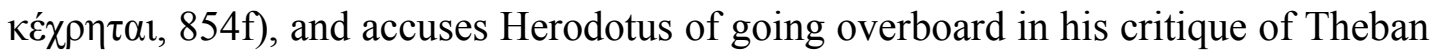
Medising: 61

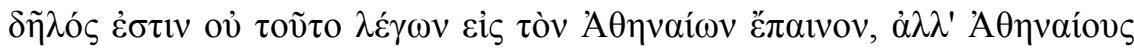

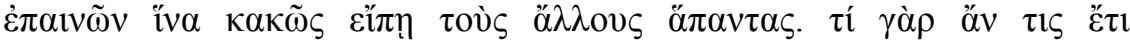

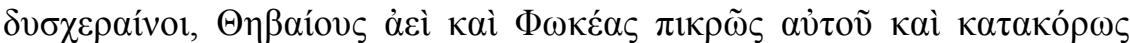

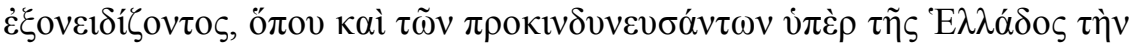

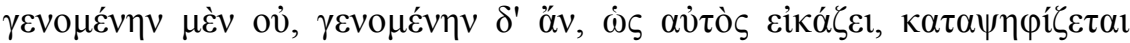
$\pi \rho o \delta$ óíav;

$\mathrm{He}$ is clearly not saying this to praise the Athenians, but praising the Athenians to that he may speak ill of all the others, for how can one be outraged that he always bitterly and intemperately recriminates the Thebans and Phocians, when he condemns the treason of those who put themselves in danger's way for Greece, which never actually happened, but, he suspects, could have happened? (864a-b)

\footnotetext{
${ }^{60}$ Perhaps specifically Corinthians, see $A C T$ 3:53 for a summary of the views.

${ }^{61}$ Plutarch reports a story from the Theban historian Aristophanes ( $=F G r H 379 F 5$ ) that the Thebans had refused to buy Herodotus' goodwill (864d), unlike the Athenians (862b). Bowen (1992), 130, suggests that Aristophanes' story is a product of the same kind of malice which Plutarch bemoans in Herodotus. See De Hdt. mal. 864d-65f, for a more extensive critique of Herodotus' treatment of Theban Medism.
} 
Many of his specific accusations are demonstrably unreasonable; scholars have suggested therefore that the work is a rhetorical exercise rather than a serious critique of historiography. ${ }^{62}$ It does not necessarily follow that there was absolutely no substance to Plutarch's suggestion that Herodotus did not always fairly represent Boeotian history. ${ }^{63}$ Some of the historical information against which Plutarch compares Herodotus' narrative is genuine. ${ }^{64}$

In general Plutarch compares Herodotus' historiographical style unfavourably to that of Thucydides (e.g. 855c, f). Thucydides, however, does not seem to have followed Boeotian sources in his history. His few statements on Boeotia's internal affairs seem to take their lead from the general Athenian disparagement of Boeotia. The same accusation of anti-Boeotian bias, and especially anti-Theban bias has frequently been brought against Xenophon, in particular because parallel sources for his period sometimes demonstrate very different accounts (for example, on the causes of the Corinthian War). ${ }^{65}$ It is easy to construct rationalisations for Xenophon's dislike of Thebes, given his personal relationship with King Agesilaus of Sparta and the death of his son Gryllus at the Battle of Mantinea. ${ }^{66}$ However, Cawkwell has argued that Xenophon gives credit where due, while Gray argues that Epameinondas is one of Xenophon's exemplary leaders. ${ }^{67}$ His bias seems to result in omission rather than deception. ${ }^{68}$ On the whole, Xenophon's Thebans must be approached with only due caution.

This thesis relies largely on historiographical sources, often produced by nonBoeotian authors employing (if any) Boeotian sources which were not likely to be favourable to Thebes. Not only is it difficult therefore to prove an imperialist attitude

\footnotetext{
${ }^{62}$ Mossman (1995), 227. Russell (1973), 60-62, and Bowen (1992), 2, argue for the sincerity of Plutarch's argument. Pelling (2011), 150-51, observes that Plutarch does not always follow his own advice, whether it was meant or not.

${ }^{63}$ Baragwanath (2008), 9-20, offers a very positive view of Plutarch's critical ability.

${ }^{64}$ For example, the Battle of Ceressus (see pp. 58-60) is attested only in Plutarch and Pausanias, but Pausanias' source is clearly not Plutarch, and perhaps not even the same source as Plutarch's. The historical validity of the comparandum does not prove Plutarch's argument that the Boeotians and Thessalians were at odds.

${ }^{65}$ Finley (1959), 382; Buck (1994), xvi. Buck (1993) argues that in the case of the start of the Corinthian (or Boeotian) War Xenophon's account is still best, although the story that the Theban Ismenias took Persian bribes to start the war should be discarded as Spartan propaganda.

${ }^{66}$ Sordi (1951), 303-4; Westlake (1985), 123.

${ }^{67}$ Cawkwell (1972); Gray (1989), 170-75.

${ }^{68}$ Buck (1994), xvi.
} 
in Theban policies, but it is also possible that the reality of individual Theban actions as a whole has been distorted.

What follows is in four parts, covering distinct aspects of Thebes' imperialism within Boeotia: Boeotian ethnic identity, Boeotian military actions, and Boeotian internal politics, and Boeotian coinage. Generally speaking, the first three of these aspects each represents a more developed stage of Theban imperialism, and therefore they are covered in broadly chronological order.

In the first chapter, I discuss the matter of Boeotian ethnic identity, which is essential to any discussion of Boeotian history. I argue that Thebes in particular relied on the ethnic identity which it shared with its neighbours as a form of control. Signs of the construction of this identity can be seen in Archaic cultural artefacts such as the Iliad; the pre-historical construction of Boeotian identity in other sources also emphasises the unitary origin of the splintered Boeotian poleis. Cultural artefacts from within Boeotian demonstrate a change in Boeotian awareness of their identity from the early Archaic Period (in Hesiod) to the end of the Archaic Period (in Pindar and Corinna). Moreover, I argue that Thebes encouraged construction and reconstruction of nascent Boeotian ethnic identity out of the shared cultural features of the Boeotians in the late Archaic Period, promoting cooperation and its own position as the natural leader of Boeotia. The evidence points towards a date around 525 for the culmination of Theban manipulation of Boeotian identity. This discussion will form the background to the discussion of Thebes' politicisation of Boeotian ethnic identity which follows.

In the second chapter, I identify a period (ca. 525-447) in which Boeotia's ethnic unity was exercised on the battlefield. Scattered historical records from the sixth century onwards attest to the military deeds of "the Boeotians": I will demonstrate that in many of these cases, Thebes was the only (or most important) identifiable state involved; it is significant therefore that these deeds were attributed to the wider community. These early and often vaguely-attested efforts have been misinterpreted as evidence that the Boeotian Confederation was already operating in the late Archaic Period. By the time of the Persian Wars, it is clear that military cooperation 
was the norm in Boeotia, and that Thebes was the acknowledged military leader of the region. It is not clear that this was substantially challenged by Boeotian defeats in the Persian Wars, and I will argue that Thebes took the lead in further developing Boeotian military cooperation into a full, political community after overthrowing Athenian domination of the region in the mid-fifth century (457-447), contrary to the arguments put forward by Fowler and Larsen that Tanagra and Orchomenus were the regional hegemons before and after the Athenian hegemony. ${ }^{69}$

In the third chapter, I argue that the constitution of the Boeotian Confederation gave the balance of decision-making power within the confederation to Thebes. This was a central and persistent aspect of the proportional division of representation to the Boeotian League. Thebes also imposed oligarchic constitutions on the Boeotian poleis: Thebes therefore held effective control over the whole of Boeotia. Perhaps most importantly, Thebes was able to draw on the Confederation's required military contributions to advance its own policies. During the Corinthian War the Spartans singled out Thebes' position within Boeotia as interfering with the $\alpha$ vovoría of the other Boeotian poleis. Thus the Boeotian Confederation should clearly be classified as an imperialist structure.

A fourth chapter independently considers the evidence of Boeotian coinage, which has often been used problematically to inform historical analysis of Boeotian relations. Hansen has argued that we cannot reliably use this coinage to elucidate specific historic developments in Boeotia. ${ }^{70}$ Moreover, Mackill and van Alfen argue that monetary unions are not necessarily subordinate to the political situation and must therefore be approached with caution. ${ }^{71}$ I will argue, based largely on the iconographic interpretation of the evidence (which is less problematic), that Boeotia's shared monetary iconography reflects Theban control, and that Boeotian monetisation may have taken place under Thebes' direction and to its benefit. Boeotian coinage shows from very early on signs of a monetary union controlled by Thebes.

\footnotetext{
${ }^{69}$ Fowler (1957); Larsen (1950).

${ }^{70}$ See p. 4 , n. 13.

${ }^{71}$ Mackil and van Alfen (2006).
} 
Overall, I argue that it is appropriate to define Thebes' relationship with Boeotia as imperialist. From the late sixth century Thebes asserted its position over other Boeotian states. This control originally constituted cultural, military, and economic spheres of influence. However, in the second half of the period considered here Thebes exercised control over Boeotia both through direct domination of the common resources of the Boeotian Confederation, and indirectly through interference in the Boeotian poleis' local governments. Most significant here is the degree of force: Thebes' consistent aggression places its treatment of Boeotia on the imperialist spectrum. 


\section{BOEOTIAN SWINE: THEBES AND THE FORMATION OF BOEOTIAN ETHNIC IDENTITY}

The purpose of this chapter is to explore the formation of Boeotian identity. Systematic interaction between Boeotian poleis relied, at the most basic level, on an inclusive group identity. Although Boeotia was divided into a number of smaller political communities, and had been so from very early in the historical period, its inhabitants shared cultural and religious practices. ${ }^{72}$ However, cultural affinity and political organisation are two very separate things. ${ }^{73}$ I argue that Thebes relied on Boeotian identity as an essential part of its imperialism throughout the Archaic and Classical Periods; it is therefore important to consider the substance of Boeotian identity throughout these periods. This discussion will form the background in particular to the discussion in chapter two of Thebes' politicisation of Boeotian identity. I discuss Boeotian ethnicity here in the context of recent work on ethnic identity in Ancient Greece, which suggests that ethnic identity was not a primitive aspect of Greek culture, but a tool which could be subject to ongoing manipulation by various agents for their own purposes; a preliminary section will discuss the analysis of ethnic identity which is relevant to this thesis. ${ }^{74}$

I show here that Theban imperialist rhetoric relied upon the belief that Boeotia was more than a geographic unit. The cooperation of Boeotian states which developed under Theban leadership was consistently referred to not without recognition of the individual poleis with their individual civic identities, nor as a collective centred on Thebes, but with reference to the region as a whole. Thebes' appeals to "shared" or "common ancestral customs" ( $\tau \grave{\alpha}$ Kovvò $\pi \alpha ́ \tau \rho ı)$ in Thucydidean speeches demonstrates that ethnic identity was part of Thebes' domineering vocabulary for its interactions with other Boeotian poleis.

\footnotetext{
72 Schachter (1994), gives a thorough overview of Boeotian "national" sanctuaries and deities. Kowalzig (2007), 328-91, discusses Archaic Boeotian religious practices; Larson (2007) discusses the general discourse of Archaic Boeotian ethnic identity.

${ }^{73}$ See Morgan (2001), for critique of the widely-held idea that ethnic groups ( $(\varepsilon \theta v \eta)$ in Greece reflected a consistent political arrangement.

${ }^{74}$ In particular, the work of Smith (1986), Hall (1997, 2002); Morgan (2003).
} 
I go on to examine the extant evidence for a Boeotian identity in Boeotia itself, looking at the works of Hesiod, Pindar and Corinna. I argue that the development of a discourse around Boeotian identity did not arise until the late sixth century. Finally, I explore the ways in which the discourse of Boeotian identity encouraged unity and cooperation within the region. As established in the preliminary section, the discourse of identity is malleable, and in the case of Boeotia some evidence suggests that Thebes encouraged reconstruction of Boeotian identity to encompass northern Boeotian states.

\section{REGIONAL ETHNICITY IN ANCIENT GREECE}

It is now widely recognised that although cultural practices may be inherited and shared between separate communities, any identity is a matter of discourse, i.e. the result of discussion which draws together cultural elements into an identity by talking about them as things held in common. ${ }^{75}$ This discussion could be directed.

Group identities in Greece had to be constructed at many levels, for the Greeks were not a unified or homogeneous people at any level. ${ }^{76}$ Political discourse emphasised the household (oĩ marriage and property ownership. Households were grouped into formal states ( $\pi$ ó $\lambda \varepsilon 1 \varsigma$ ) but individual poleis often groupings within the state (such as $\varphi v \lambda \alpha i$ “tribes”, $\gamma \varepsilon ́ v \eta$ “clans", $\varphi \rho \alpha \tau \rho \alpha i ́$ "brotherhoods", $\delta \tilde{\eta} \mu \mathrm{or} \mathrm{"villages").}{ }^{77}$ There were also groupings which stretched beyond the borders of an individual polis: ethnic grouping was one of the broad means by which an individual Greek might distinguish himself or herself from the Greeks of other poleis. The Greek terms for these supermunicipal groups vary.

\footnotetext{
${ }^{75}$ Morgan (2003), 23.

${ }^{76}$ Hall (2003); Morgan (2003), 14.

77 The translation of these terms is necessarily very loose; Greek group-identity types do not necessarily have straightforward equivalences to modern Anglophone categories. Boeotia does not seem to have had the $\varphi v \lambda \alpha i$ and $\varphi \rho \alpha \tau \rho \alpha$ í that were so important in other Greek poleis; Buck argues (1979), 90, very unconvincingly that the seven Homeric commanders of Boeotia reflect seven early Boeotian $\varphi v \lambda \alpha i ́$. Some divisions may have been multi-valent: for example, Doric poleis had $\varphi v \lambda \alpha i ́-$ divisions which often shared their name with $\varphi v \lambda \alpha$ í in other Doric poleis; but it is not clear that the Spartan Hylleis had any relationship with the Sicyonian, Megaran, Argive, Epidauran, Troezene, Theran, etc., Hylleis: see Hall (2007b), 54-56.
} 
It is important to note that the concept of "ethnicity" is extremely modern. Although "ethnicity" derives from the Greek term हैقvos, in its earliest uses the Greek word denoted any group; some have argued that the Homeric "Catalogue of Ships" may have been instrumental in transforming the word from "collective" to "people". 78 Nevertheless, the exact meaning even in the Classical Period was less than clear: the usage of $\ddot{\varepsilon} \theta v o \varsigma$ in both Herodotus and Thucydides seems only to serve as a term of contrast with the more marked $\gamma \varepsilon \dot{\varepsilon} v \varsigma$, "descent-group", 79 but the reference to the $\varepsilon \bullet \theta v \eta$ of the Boeotians and Chalcidieans in an official Athenian epigram (ML 15) should denote something more specific. ${ }^{80}$ Konstan states, "ethnicity arises when a collective identity is asserted on the basis of shared characteristics". ${ }^{81}$ Shared characteristics are, of course, the basis of any communal identity. However, the characteristics which assemble an ethnicity are usually subjective, not objective: for example, a member of the Athenian political community had to meet certain objective descent criteria which could be defined by law (e.g. Pericles' citizenship law of 451/50 BCE, [Arist.] Ath. Pol. 26.3) and could be tested in court ([Dem.] 59). Membership within ethnic groups was only contestable on subjective grounds. ${ }^{82}$

Smith assembles six characteristics for ethnic groups: a collective name, a common myth of descent, a shared history, a distinctive culture, an association with a specific territory, and a sense of solidarity. ${ }^{83}$ Smith notes that although some shared characteristics only need to be highlighted in discourse, others will be augmented "along those of the six dimensions they appear to be deficient in". ${ }^{84}$ Hall suggests that a shared myth of descent and an association with a specific territory are particularly important for the development of ethnicity in Greece. ${ }^{85}$ These dimensions are a matter of subjective consideration; they relate not to factual descent, history, cultural practice, territorial possessions, but to the presentation of

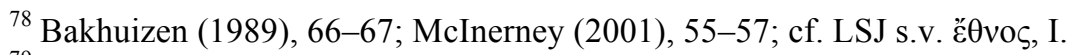

${ }^{79}$ C. Jones (1996), esp. 319-20.

${ }^{80}$ Hall (2007b), 50.

${ }^{81}$ Konstan (2001), 30.

82 The locus classicus is Cleomenes' assertion that he is not Dorian but Achaean (Hdt. 5.72.3). His assertion is accepted by the Athenian priestess, but Herodotus implies in his ensuing discussion that the following problems may have been a consequence of impiety resulting from Cleomenes' claim.

${ }^{83}$ Smith (1986), 22-30.

${ }^{84}$ Smith (1986), 31.

${ }^{85}$ Hall (1997), 25.
} 
these factors as a means of distinguishing in-groups from out-groups, as a matter of discourse.

Scholarship has rejected the belief that ethnic identity is itself innate, or based on innate characteristics which naturally create identity (the primordialist model). The fulfilment of ethnic characteristics in any particular case is not necessarily organic; characteristics can be constructed or reconstructed to serve the process of ethnogenesis. The instrumentalist school argues that characteristics are not simply selectively collated into a cohesive identity, but that ethnogenesis can serve a wider purpose, as opposed to the primordialist view of ethnogenesis as a directionless development of cultural similarities. Hall states that

\section{there is nothing inevitable or primordial about ethnicity... Biological features, language, religious professions, or cultural traits, far from defining ethnic groups, are variously harnessed to serve as visible markers for identities that are constructed discursively. ${ }^{86}$}

In the instrumentalist model, features are attached to the discourse of identity, rather than features engendering the discourse. It is worth noting Konstan's assertion that "such discursive processes occur as a result precisely of 'changing social contexts,' that is, of events to which the formation of an imagined identity is a response": the instrumentalist model of ethnic identity encompasses primordialist models. ${ }^{87}$ Discussion of Boeotian identity has tended to take a primordialist approach to ethnic identity, although the Boeotians were only unequivocally unified during their mythical prehistory: there is no extant account for their division into separate poleis. This can be compared with the Dorian invasion, which includes a narrative of division (cf. Paus. 4.3.3).

Hall suggests another heuristic for discussing ethnicity, opposing ethnogenesis focusing on differences between the in-group and out-groups ("oppositional" identity) against ethnogenesis which focuses on similarities within the in-group ("aggregative" identity). ${ }^{88}$ Oppositional identity has been considered particularly important in the formulation of Greek ethnic identity: the waves of Greek

\footnotetext{
${ }^{86}$ Hall (2007), 53; see also Hall (1997), 21-24.

${ }^{87}$ Konstan (2001), 30.

${ }^{88}$ Hall (1997), 47-8.
} 
colonisation in the early Archaic Period and the united struggle against the Persian Empire at the end of the Archaic Period in particular may have encouraged Greek contrastive ethnogenesis by bringing Greeks into contact with non-Greek peoples. ${ }^{89}$ At the same time, the rise of Panhellenism may itself have been essential to the contrastive ethnogenesis of groups within Greek culture as Panhellenic festivals and sanctuaries (such as Olympia and Delphi) brought Greeks in contact with other Greeks. This differentiation relies on an instrumentalist (or, at least, nonprimordialist) analysis, as the distinction lies not in the traits used for ethnogenesis themselves, but the focalisation of these traits in the discursive representation of ethnic characteristics. Contrastive ethnic construction infers, rather than overtly identifies, commonalities within the in-group.

Morgan notes that the six characteristics which Smith identifies have also been used, problematically, as characteristics in the construction of Greek poleis. ${ }^{90}$ In part (as Morgan suggests) this is a matter of terminological slippage between ethnic and political identities, but the mechanisms of identity can work equally well in constructing both political communities and ethnic identities (a point in favour of the instrumentalist model). Morgan is cautious about associating ethnic identity with civic communities; but Boeotia stands on the traditional border between the poleis of southern Greece and the $\check{\varepsilon}^{\prime} \theta v \eta$ of northern Greece. ${ }^{91}$ In Boeotia, therefore, civic and ethnic identity operated at the same time. An individual Boeotian could validly refer

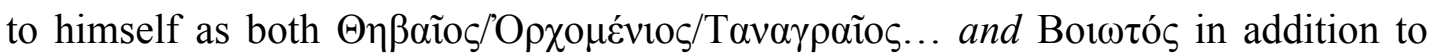
the broad Panhellenic identities (for the Boeotians, Aionعv́c).

The formation of separate ethnic identities within Greek culture was, to some extent, a prehistoric phenomenon. ${ }^{92}$ Recent scholarship on the linguistic evidence has demonstrated that although the extant corpus of Mycenaean Greek Linear B tablets demonstrates remarkable linguistic unity, the everyday speech of Bronze-Age Greece varied substantially across the southern Balkan Peninsula and Aegean

\footnotetext{
${ }^{89}$ Hall (1997), 47-8;

${ }^{90}$ Morgan (2003), 79.

${ }^{91}$ Hall (2007), 59.

${ }^{92}$ Morgan (2003), 17.
} 
Islands. ${ }^{93}$ Finkelberg's reconstruction of a Greek dialect continuum based on the evidence of later isoglosses is predicated on identity-based groups: when the dialects moved into the non-continuous arrangement which is attested by the historical evidence, each must have moved with large groups. Without more detailed evidence on Bronze-Age isoglosses, we cannot determine whether the dialects contained one linguistically-unified isogloss group each, or multiple isogloss groups which were unified under a non-linguistic criterion. In either case, the dialect movements in Finkelberg's reconstruction, which she links to the late Bronze-Age (SubMycenaean) population movements, demonstrate indicia of early ethnic identity within Greece. Likewise, the Homeric epics depict various subgroups within the Greek and Trojan forces: although these divisions seem to be solely political within the epics, as the Achaeans seem to belong to a monolithic culture and language, it seems likely that Greeks even from the Archaic Period would have understood (or perhaps retrojected) their own cultural and linguistic diversity onto the Homeric depiction.

Some Boeotian identity probably dates back to Bronze Age. It seems likely that the Boeotians were defined in part by their dialect. ${ }^{94}$ Dialectal distinction was both an aggregative and constrastive characteristic, one which joined the Boeotians and contrasted them with other Greeks. The historical area of Boeotian dialect (a mixture of Aeolic and North-Western Greek) was bordered by Attic, Ionian and Doric linguistic areas. The linguistic community of Boeotia is undeniable and may have been a substantial contributor to Boeotian identity. ${ }^{95}$ However, Finkelberg reconstructs Boeotian dialect as part of a Greek language continuum in the Bronze Age period, with the Boeotians placed approximately in the area of Thesprotia which the Greeks considered to have been the Boeotian homeland. ${ }^{96}$ It is probable, given the language continuum, that Boeotian dialect was not the sole aggregative feature of Boeotian ethnic identity: when they moved it must have been on some greater identity.

\footnotetext{
${ }^{93}$ Finkelberg (2005), ch. 6.

${ }^{94}$ See C. Buck (1955), 152-54, on the features of Boeotian dialect, which was highly distinctive.

${ }^{95}$ See Larson (2007), ch. 4, on Boeotian dialect as an indicium of ethnic identity. Language was very highly privileged in Greek ethnic discourse: Anson (2009).

${ }^{96}$ Finkelberg (2005), ch. 6.
} 


\section{ETHNICITY AND THE CONFEDERATION}

The term "Boeotian Confederation" is a result of the modern historiographic tradition: although the residents of Boeotia cooperated politically, religiously and militarily with each other within increasingly formal structures from the Archaic Period onwards, it was not until the late fourth century that the Boeotians began to use a term for their collective political actions which could strictly be translated as a

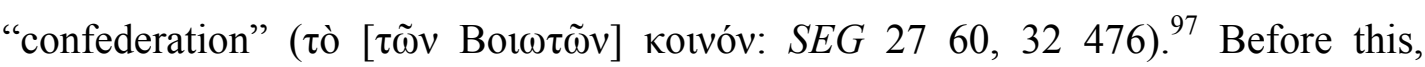
justifications of the cooperative nature of Boeotia referred solely to "the ancestral

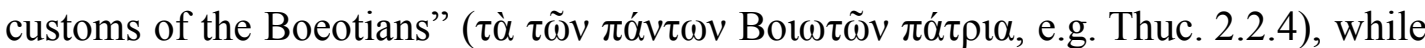

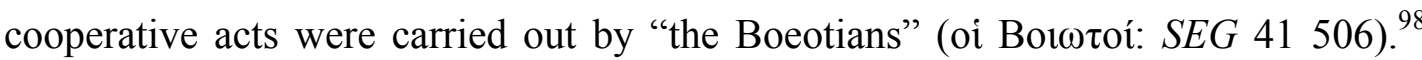
Even the highly structured federal bodies of the later fifth century and early fourth

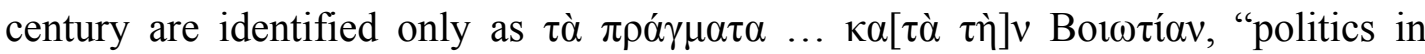
Boeotia" (Hell. Oxy. 16). The cohesion of Boeotia was dependent then on the ethnic identity of the participating states, represented by the ethnic term "Boeotians"

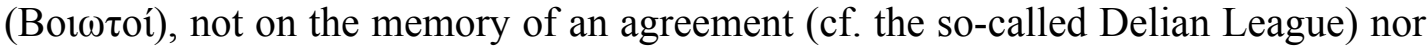
on geographic proximity ( $\mathrm{cf}$. the so-called Peloponnesian League). The continuing use of the ethnic, whether to refer to mythological and prehistorical Boeotians, the inhabitants of the region in the Archaic Period, or the citizens of the fifth-century confederation, erases the development of the term; but this does not indicate per se that Boeotia had always had a degree of political unity. It is important to consider

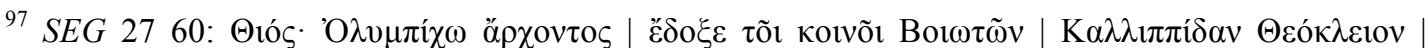

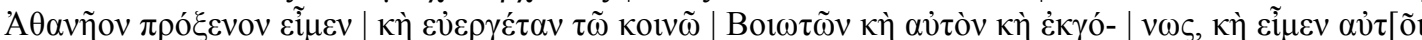

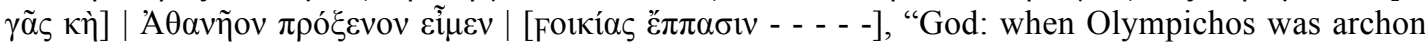
the Boeotian confederation decided that Callippidas [son of Theocles?] of Athens should be proxenus and euergetes of the Boeotian confederation, both himself and his decendants to be proxenus of this land and to have the right to hold such territory."

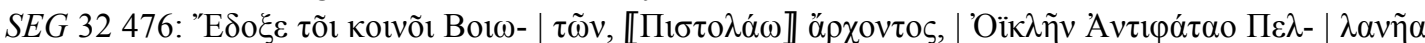

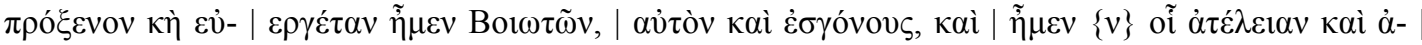

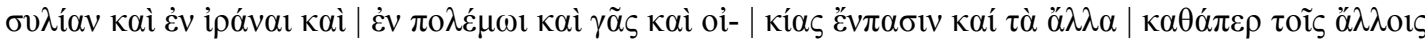

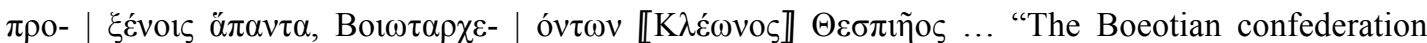
decided, when Pistolaus was archon, that Oicles son of Antiphatas from Pellana should be proxenus and euergetes of the Boeotians, both himself and his decendants, and that he will go without taxation or harm in peace and in war and have the right of territory and residence and such other things as the other proxeni, when the Boeotarchs were Cleon the Thespian ..."

Both inscriptions dated to after 338: Rhodes and Lewis (1997), 121.

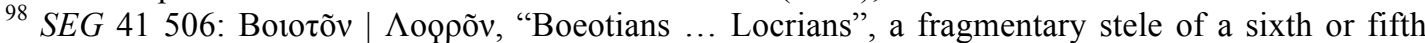
century agreement between Boeotians and Locrians found at Delphi. Boeotian proxeny decrees from the early fourth century (perhaps relating to the Theban navy, cf. Fossey [1994], 35-36) appoint

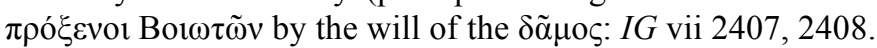


what exactly "Boeotian" meant, whom it denoted, and how it was used in the Archaic Period.

Although the Boeotian Confederation, like the Peloponnesian League, had an obvious geographical unity, two points need to be observed: firstly, the Peloponnesian League encompassed political units which identified with several different groups and for whom geography was the only in-group characteristic: Dorian Spartans, Achaean Messenians, Aetolian Eleans, Arcadians; ${ }^{99}$ while the Boeotian Confederation incorporated a geographic and ethnic unity. The Peloponnesian League was apparently bound by individual treaty to Sparta. No sign of formal agreements exists for Boeotia until the late fifth century. Secondly, while

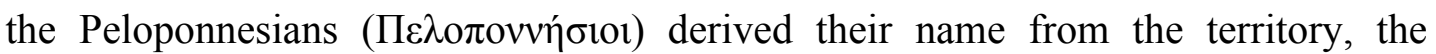

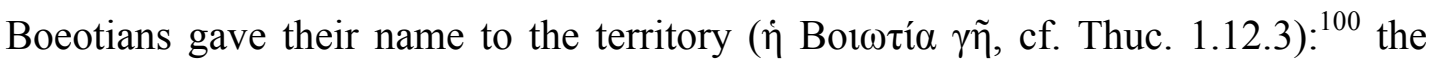
territory was defined, at least in discourse, by the extent of its inhabitants and not vice versa. In both cases the expansion of an otherwise unmarked collective noun with political ideology presumes the participation of the pre-existing group, perhaps beyond the true subscription to the ideology, and reforms the identity of the group around a new focus.

The use of the ethnic alone for the cooperation relies on the fellow-feeling of the

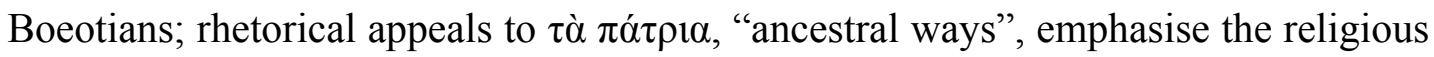
and cultural background to the present political super-community. The Boeotians were occasionally referred to as an $̌$ evo 16.4). An "̌̈ 0 vo was not an "ethnic group" per se, but a broad term for identity groups, including but not limited to the inhabitants of a single polis (e.g. Athens, Hdt. 1.57.3), of multiple poleis in a region (e.g. Boeotia), or even of much larger and even non-Greek groups (e.g. Scythians, Hdt. 4.5). ${ }^{101}$ In northern Greece, the urbanised political structures of the polis were not favoured; the term for these collections of settlements likewise seems to have been $\varepsilon^{\theta} \theta \mathrm{v} \eta$. German scholarship in particular has suggested that $\varepsilon^{\prime} \theta \mathrm{v} \eta$ which formed a collective political stucture

\footnotetext{
99 And in fact included Aeolian Boeotians until the end of the Peloponnesian War, who were not Peloponnesian in any sense.

${ }^{100}$ Hansen (2004), 431, is mistaken to identify Hesiod $f r .181$ as a reference to the territory; it is simply the feminine of the variant ethnic Botótıৎ (cf. Pind. Ol. 6.90).

${ }^{101}$ Hall (1997), 34.
} 
(Stammesbund) were a distinct political structure from the polis-based federations, кovvó (Stadtsbund). ${ }^{102}$ Boeotia's marginality between the northern system of é $\theta v \eta$ and the southern system of poleis (and its close cultural ties with Thessaly in particular) reinforces the view that cooperation was a pre-historical phenomenon amongst Boeotians, of which confederation was only a more developed form. However, as Morgan points out, है $\theta v o \varsigma$ is not a consistent term for any political structure, and there is very little evidence to suggest that the political structure of Boeotian poleis was less developed than those in southern and eastern poleis. ${ }^{103}$ Considerations of Boeotian unity cannot, therefore, be founded upon generalised assumptions about the character of Greek $\varepsilon \theta v \eta$. Ethnic identity was nevertheless an essential part of the pre-Hellenistic relationship between Boeotian poleis, though it must be considered in its own right.

The political associations possible in the originally ethnic term "Boeotian" are clear in Herodotus' report of the Corinthian settlement of the sixth-century dispute at Plataea: ${ }^{104}$

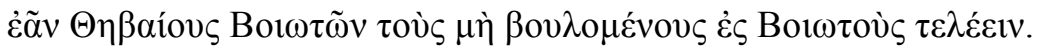

[the Corinthians decided] that the Thebans were to leave alone those of the Boeotians who did not wish to be considered amongst the Boeotians. (6.108.5)

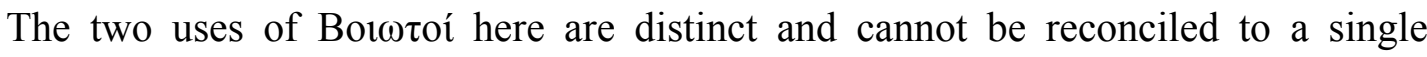
meaning: the first must mean the ethnic group, the second the political collective. However, Herodotus offers no distinction between the general ethnic and a more significant category: the use of these terms side-by-side, in this context, suggests an ongoing politicisation of the ethnic into a technical term. This can be compared with the expanding use of $\Lambda \alpha \kappa \varepsilon \delta \alpha \mu$ óviot to include Spartan perioecic communities in the late Archaic Period. ${ }^{105}$

Other events reflect the substantial weight which Thebes placed on Boeotian ethnic identity in its negotiations with the Boeotian poleis. The historiographical record offers limited views of the discourse between Thebes and the other Boeotian poleis

\footnotetext{
102 Gschnitzer (1955); (1960), 11-28; Morgan (2003), 6-7.

${ }^{103}$ Morgan (2001); (2003), 7.

${ }^{104}$ See pp. 52-58, on the context of this arbitration.

${ }^{105}$ Hall (2000).
} 
about their relationships. The recurrence of conflict between Thebes and Plataea at the start of the Peloponnesian War, however, offers a rare glimpse into such discussions, albeit largely through the genre of the Thucydidean speech, which is

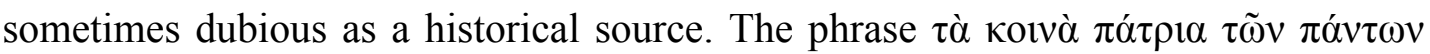

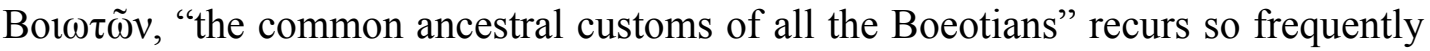
in Theban speech as to suggest a catchphrase:

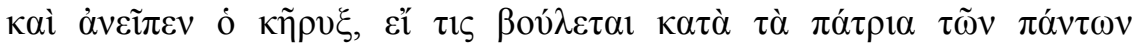

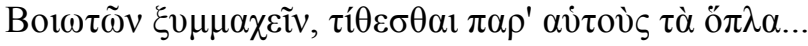

The herald proclaimed that anyone who wished to fight with them, according to the ancestral customs of all the Boeotians, should pile their arms with theirs. (2.2.4)

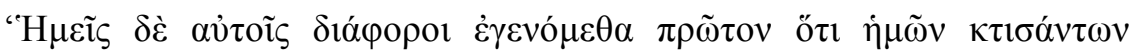

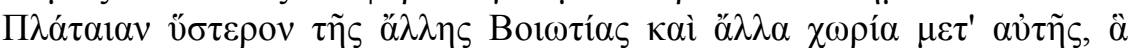

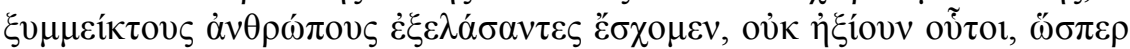

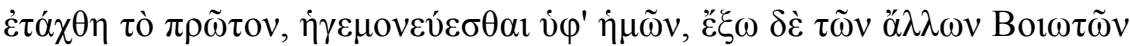
$\pi \alpha \rho \alpha \beta \alpha i ́ v o v \tau \varepsilon \varsigma \tau \grave{\alpha} \pi \alpha ́ \tau \rho 1 \alpha \ldots$,..

We first came to disagreement because we had founded Plataea after the rest of Boeotia, and other areas with it, which we had gained by driving out the previous mixed population; these men did not accept our leadership as had been originally arranged, but stood apart from the other Boeotians and rejected the ancestral customs. (3.61.2)

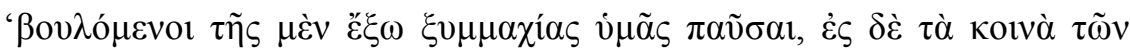

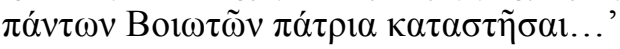

wishing to stop you from being outside the symmachy and to bring you into the common ancestral customs of all the Boeotians. (3.65.2)

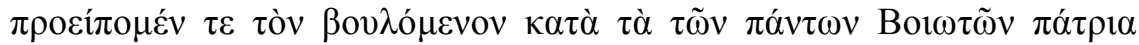

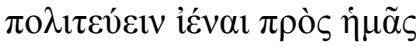

.... and we announced that he who was willing to participate according to the ancestral customs of all the Boeotians should come over to us. $(3.66 .1)$

These passages are from Thucydides' description of the Theban invasion of Plataea in 431 and the subsequent debate between Plataea and Thebes in 427; we may note that Plataea was at the time the most recalcitrant Boeotian state towards Theban hegemony of Boeotia. All of the instances of the phrase belong to Theban speeches (sometimes indirectly reported): in discussing its attempts to bring Plataea into its sphere of influence, some of them forcible, Thebes did not appeal to a particular political structure or agreement, but simply to Plataea's Boeotian identity. Thebes even establishes itself as a pseudo-metropolis of Boeotia, claiming to have "settled"

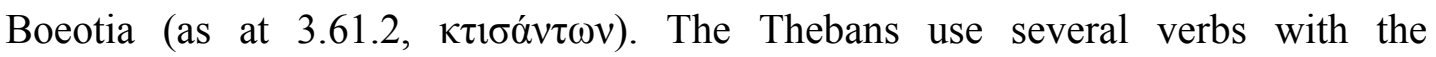

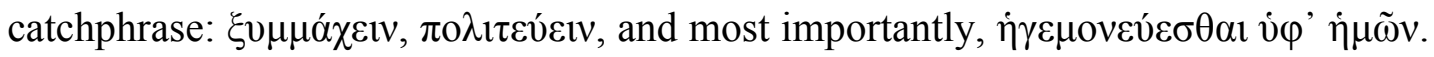




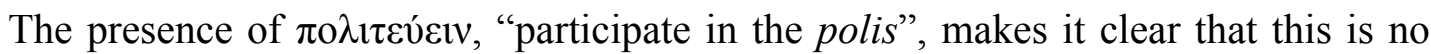
simple reference to military leadership: Thebes claimed a consistent right to lead the Boeotians, perhaps as metropolis.

The ethnic identity of the Boeotians was clearly important to Thebes' ways of dealing with the other Boeotians. The political leveraging of the ethnonym in particular to create a new political community which included all Boeotians under Theban domination did not necessarily rely on a fundamental or primitive Boeotian understanding of their own identity. This politicised ethnic identity was used continuously from the sixth century as the label for cooperation between Boeotian poleis.

\section{THE FORMATION OF BOEOTIAN IDENTITY}

The development of a significant ethnic identity in Boeotia seems to have been a late-occuring process. The Early Boeotian author Hesiod shows little awareness of any regional ethnic identity. By the first years of the Classical Period, however, Pindar and Corinna demonstrate marked awareness of their Boeotian-ness.

Unlike Homer, whose identity could not be ascertained from his poetry, Hesiod was held to have been both poet and major character in the Theogony and Works and

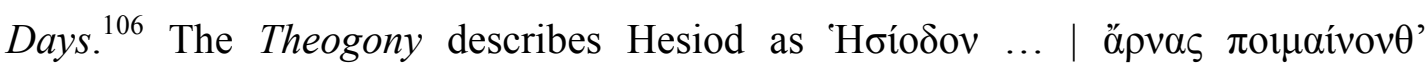

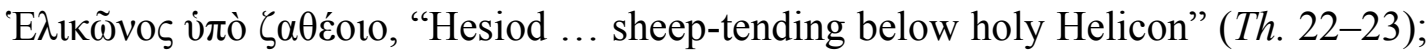

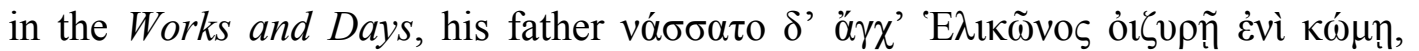

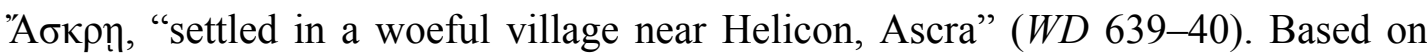
these brief pieces of information and the strong association of the poet(s) of both poems with the character Hesiod, the ancient Greeks described the poet Hesiod as Boeotian. $^{107}$

Hesiod never uses the term "Boeotian" in his poetry. The poems are not unaware of

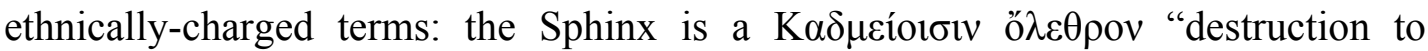
Cadmeans" (Th. 326); Cyme is Aio $\lambda$ í $\delta \alpha$ "Aeolian" (WD 636); the sun shines

\footnotetext{
${ }^{106}$ Ready (2007), 130.

${ }^{107}$ E.g. Bacchyl. 5.191-92; Hermesianax fr. 7.21-26; some sources restrict themselves to "Ascran",

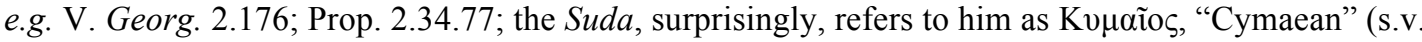
Нбíodos).
} 


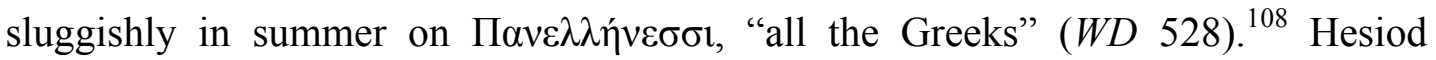
traveled to Euboea (presumably from Ascra): unless he sailed from the southwestern coast of Boeotia around the Peloponnese and Attica to Euboea, he must have traveled across southern Boeotia at least once and come into contact with the occupants (WD 650-55). Despite a consciousness for ethnicity, Hesiod uses no word for himself or his neighbours as a distinct group from the wider Panhellenic culture which he depicts.

Hesiod also eschews the local Boeotian dialect for the Ionian epic literary dialect. Even the Aeolian substratum in Hesiod's Ionic poetry employs only those Aeolicisms which may also be found in Homer. Cassio notes that these features nevertheless have a higher rate of occurrence in Hesiod, but also that Hesiodic language often has clearly Ionic features contrary to Boeotian dialect: particularly the neglect of initial [w] (digamma, F) in Hesiod against the preserved [w] of the Boeotian dialect down to the Hellenistic period. ${ }^{109}$ The only undoubtedly Boeotian element in the language of the Theogony or Works and Days is the Boeotian form of the Sphinx's name (Фĩ火', Th. 326). ${ }^{110}$ On the basis of this evidence, we cannot even state with certainty that Hesiod spoke Boeotian dialect normally: he presents his father as native of Aeolia (WD 636). ${ }^{111}$ Hesiod is unique amongst Archaic poets for describing local issues (notably the dispute of his own inheritance with his brother Perses) from a Panhellenic perspective: Homer takes a broadly Panhellenic stance as well, while the lyric poets describe local and personal problems (such as the $\beta \alpha \sigma \iota \lambda \tilde{\eta} \alpha \varsigma$ $\delta \omega \rho о \varphi \alpha ́ \gamma o u \varsigma$ "gift-eating kings" of Thespiae: WD 38-39) from local and personal perspectives. ${ }^{112}$ Nagy notes that this Panhellenising movement is internalised in the Theogony, with the Muses relocated to Olympus from Helicon (Th. 52-79). ${ }^{113}$

\footnotetext{
${ }^{108}$ West (1978), 292. But see p. 36 n. 136 on Hall.

${ }^{109}$ Cassio (2009), 192-96.

${ }^{110}$ Cassio (2009), 193; in this line, at least, the Attic and Ionic form $\Sigma \varphi \tilde{\gamma} \gamma^{\prime}$ cannot be substituted in. Some codices do have $\Phi i ́ \gamma \gamma$ ' or $\Sigma \varphi^{i} \kappa^{\prime}$ (dialectal hybrids) or $\Sigma \varphi^{\prime} \gamma \gamma^{\prime}$; the scholia (ad loc.) assert the Boeotian form, and those beginning with $\Sigma \varphi$ - are unmetrical.

${ }^{111}$ See West (1978), 30, on Hesiod's father's dialect.

112 See Edwards (2004), esp. 64-79 on Ascra's relationship with Thespiae as depicted in the Hesiodic epics.

${ }^{113}$ Nagy (2009), 285.
} 
On these grounds, and accepting the modern consensus of an early to mid-seventhcentury date for Hesiod's work, ${ }^{114}$ we might conclude that either Boeotian identity in the early Archaic period was not significant enough to find expression in Hesiod's poetry, or Hesiod himself (of recent Aeolian descent) was not assimilated to the culture of his locality. This second possibility is no less evidence of the insignificance of Boeotian identity, for it is clear that ethnic assimilation is not a concern of the world of the Works and Days.

The very earliest historical attestation of Boeotian cooperation in the religious sphere comes from two dedications to Athena Pronaea at the sanctuary of Apollo Ptoeus near Acraephnium. One, securely dated to the early sixth century, reads simply Botozoí Прovaíal, "from the Boeotians to Pronaea"; the second is not much longer, and the middle part of the inscription (including the plural ending of Bototoi) requires reconstruction. ${ }^{115}$

By the early Classical Period, however, Boeotian ethnic identity was clearly operative and a significant aspect of personal identity for the residents of Boeotia. The Theban poet Pindar shows particular concern for the wider Greek perception of Boeotian character in two poems:

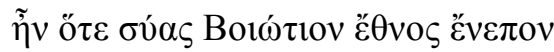

There was a time when they called the Boeotian race pigs... (fr. 83.1)

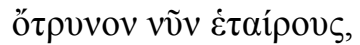

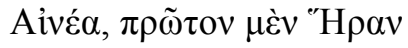

$\Pi \alpha \rho \theta \varepsilon v i ́ \alpha v \kappa \varepsilon \lambda \alpha \delta \tilde{\eta} \sigma \alpha 1$,

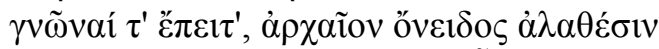

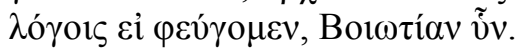

Rouse now your companions, Aeneas, first to praise Parthenian Hera, then to know if we have escaped the old reproach of unforgettable speeches, Boeotian pig. (Ol. 6.89-90)

Boeotian identity for Pindar, of course, existed in tandem with his identity as a Theban. Although Pindar does seem to be the first historical Boeotian author

\footnotetext{
114 Janko (1988), 98, concludes a terminus post quem of the Lelantine War (ca. late eighth century) and an ante quem of ca. 660 for the Theogony, preferring something later in that range, with the Works and Days later than the Theogony; West's $(1966,40-48)$ terminus post quem is ca. 750 and his ante quem ca. 650, but he sees Hesiod as more contemporary with the Lelantine War, ca. 730-700. Kõiv (2011), posits a date ca. 700, based not on linguistic evidence but ancient tradition.

${ }^{115}$ Larson (2007), 132-33.
} 
(compared with Hesiod's semi-mythical status even within his own poetry), we cannot always be sure that his "I" and "we" are sincere representations of himself. I will take a largely optimistic view. Despite the obvious hostility of many mainland Greeks to Thebes for its role in the Persian Wars, Bakhuizen suggests, based on these two references, that the low opinions of Boeotians expressed in fifth-century Attic voices had a much older origin. ${ }^{116}$ This could have been a significant feature of oppositional ethnogenesis for the Boeotians. ${ }^{117}$ Pindar remains the earliest attestation of this reproach; there is therefore little evidence to suggest that the phrase "Boeotian pigs" is "ancient" rather than simply "old". The term could easily have its basis in the disputes between Athens and Boeotia at the end of the sixth century, perhaps reinforced by Boeotian Medism during the Persian Wars at the end of the Archaic Period, only shortly before Pindar's own floruit.

Nor was the expansion of active Boeotian identity limited to Thebes in Pindar's time. The Tanagran poet Corinna, active at the same time as Pindar, ${ }^{118}$ claims that she is going to expand upon Boeotian tales for her audience of local maidens:

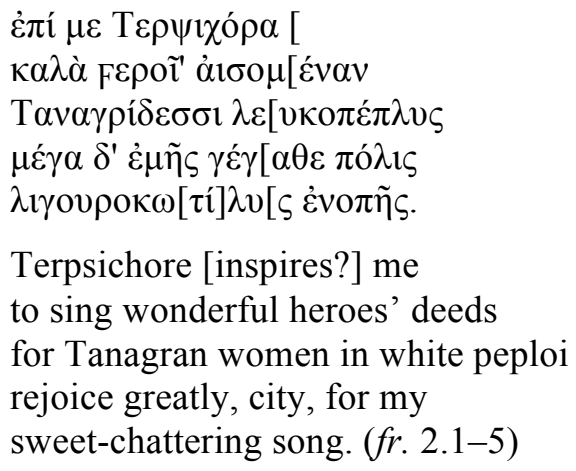

As Skinner points out, not just the use of Boeotian dialect in general but the specific Boeotian term Fepoĩ , "heroic tales", places Corinna firmly in a broad Boeotian tradition. ${ }^{119}$ The surviving fragments of her poems suggest a broad engagement with

\footnotetext{
${ }^{116}$ Bakhuizen (1989), 68.

${ }^{117}$ Bakhuizen (1989), 69.

118 Biographical tradition, although untrustworthy, widely reports Corinna as a contemporary of Pindar (Suda, s.v. Kóptvva, Plut. De glor. Ath. 4.347f-348a, Ael. V.H. 13.25, Paus. 9.22.3). The linguistic evidence of Corinna's Boeotian dialect shows her to either be genuinely early Classical or rigorously archaising. In the absence of clear evidence from the poems themselves, it is not entirely wrong to take an optimistic view of the consistent biographical tradition: see Larson (2007), 19 n. 12 , for a summary of the arguments for an early or late date. An early date is so far impossible to disprove.

${ }^{119}$ Skinner (1983), 11.
} 
various Boeotian myths, including the Seven Against Thebes and the Boeotian eponym Boeotus (frr. 5, 6). It is clear and significant that Corinna saw herself as a resident of Boeotia.

What is noticeable then is that Boeotian identity underwent a remarkable change between Hesiod's mid-seventh century writings and the end of the Archaic Period. While Hesiod expresses no concern for his own ethnic identity, it is a significant and confirmed part of Pindar's and Corinna's identity. The earliest use of the ethnic from within Boeotia occurs only in the early sixth century, with a religious aspect. I therefore suggest that the mid-sixth century is a good terminus ante quem for the discursive politicisation of Boeotian identity. This would place the phenomenon at a time roughly contemporary with traditional dates for the formation of the Boeotian Confederation.

\section{“PROJECT BOEOTIA": IDENTITY AND BOEOTIAN UNITY}

Smith highlights a sense of solidarity as one of the fundamental aspects of the construction of ethnic identity. This is especially important for explaining the emergent cooperation within Boeotia, where ethnic identity came to replace parts of the political aspects of identity of individual poleis; Kowalzig refers to the development of cooperative Boeotian identity as "Project Boeotia". ${ }^{20}$ The assumption that Boeotia consisted of states whose cooperation was prehistorical is insufficient to explain this. As discussed in chapter two, Boeotian political cooperation did not really occur until the mid-fifth century, and military cooperation only predated this by about half a century. It is important to consider how the discourse of Boeotian identity encouraged cooperation.

\section{a. The Coming of the Boeotians}

It is widely accepted that the Boeotians moved, more or less en masse, into Boeotia shortly after the Trojan War, according to mythological accounts, as a result of a conflict with the Thessalian neighbours of their original territory in Thesprotia; historically this migration may have been part of the upheavals which followed the

${ }^{120}$ Kowalzig (2007), 355. 
Mycenaean collapse. ${ }^{121}$ The accounts of migration vary wildly; Buck has attempted to synthesise the stories. ${ }^{122}$ The migration narrative is very important for our understanding of Boeotian ethnic identity: it implies that by the end of the Archaic Period, the Boeotians had been a cohesive group arranged on an operational ethnic identity for at least five hundred years. The war with the Thessalians would have been a major event in the shared history of the Boeotians, one which explained both their cultural affinities with the Thessalians and their association with central Greek territory. However, the sources describe a rather more complicated narrative than the (perhaps excessively) rationalised story given in modern accounts.

Thucydides alone fully develops the narrative which Buck uses as the basis for his account. In the "Archaeology" of Book One, Thucydides includes the Boeotian invasion alongside the Dorian invasion in a description of the aftermath of the Trojan War:

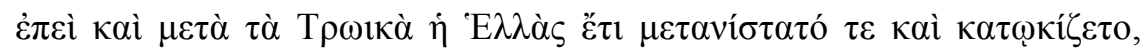

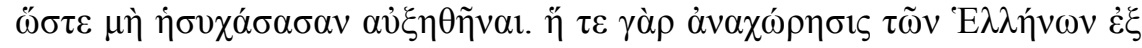

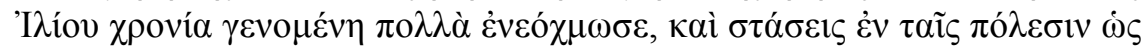

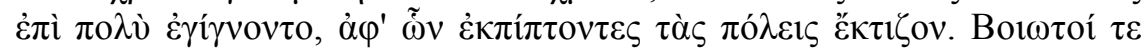

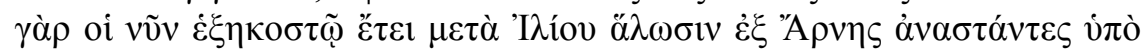

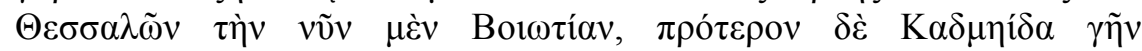

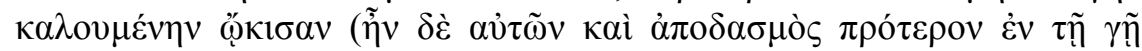

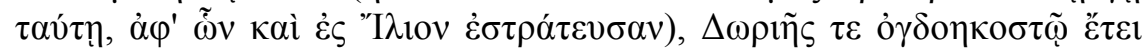

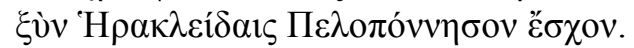

Even after the Trojan War, Greece was still being uprooted and resettled, so that it had no respite to grow. For the late-occurring return of the Greeks from Ilium caused many changes, and strife arose in almost every state, the exiles from which established the states. For the modern Boeotians were expelled from Arne by the Thessalians in the sixtieth year after the capture of Ilium and settled the modern Boeotia, previously called the Cadmean land (but there was also a section of them in that land earlier, some of whom also waged war at Ilium), and the Dorians with the Heracleidae took the Peloponnese in the eightieth year. (1.12.1-3)

The two events stand out in the narrative of the "Archaeology" for the vivid and clear descriptions. ${ }^{123}$ In fact, rather more detail is given regarding the Boeotian migration than the (perhaps better-known) Dorian invasion. Thucydides explicitly dates the Boeotian and Dorian migrations relative to the Trojan War, while an earlier

\footnotetext{
${ }^{121}$ N. Hammond (1976), 135.

${ }^{122}$ Buck (1979), ch. 5 (whence the title of this section), but see now also Larson (2007), 52-64, for a careful consideration of Thucydides.

${ }^{123}$ Finley (1972), 17.
} 
Boeotian migration has only the terminus ante quem of the Trojan War. The two stages of immigration is a theme of depictions of the "Coming of the Boeotians", ${ }^{124}$ but it is only in Thucydides, the earliest surviving depiction, that the earlier immigration is linked to the Trojan War. It seems that the aside is largely an attempt to rationalise the tradition known to Thucydides with the depiction of Boeotians at Troy in the Iliad. ${ }^{125}$ However, the term $\dot{\alpha} \pi$ o $\delta \alpha \sigma \mu$ ó $\varsigma$ seems insufficient to fully explain the fact that a large band of Boeotians and no Cadmeans participate in the Achaean force at Troy. The Boeotian tradition does appear earlier, briefly, in Herodotus' examination of the Boeotian origins of the Athenian tyrant-slayers Harmodius and Aristogeiton:

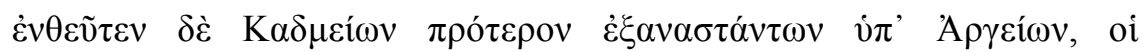

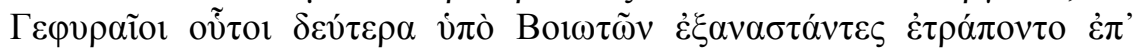
A $\theta \eta v \varepsilon ́ \omega v$.

After the Cadmeans had first been expelled from there [Tanagra] by the Argives, these Gephyrians were expelled second by the Boeotians and came to Athens. (5.57)

Although Herodotus seems to imply that the Boeotians arrived in a land from which the Cadmeans had already been ejected, there is no mention here of a two-stage Boeotian immigration. Herodotus is careful to note that the name "Boeotia" was the

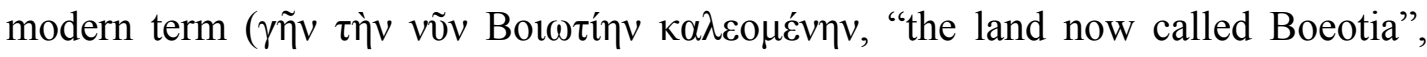
5.57), consistent with the statement in Thucydides. The source for both Herodotus' and Thucydides' accounts is quite probably Hellanicus' Troica: we might therefore conclude that the differing detail of the earlier stage of invasion ( $\dot{\alpha} \pi \circ \delta \alpha \sigma \mu$ ó $\zeta)$ is Thucydides' own theory of the Coming of the Boeotians. Given Thucydides' general tendency to respond to the Iliad in the "Archaeology", we should take Thucydides'

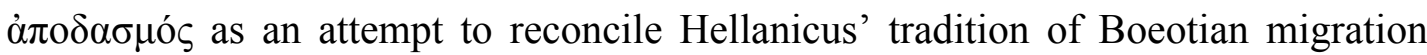
after the Trojan War with the Iliad itself, which (as Thucydides knew it) placed the Boeotians in his contemporary Boeotia at the time of the Trojan War.

Polyaenus $(1.12,8.44)$ gives two different stories regarding conflicts between Boeotians and Thessalians, while a great many different versions detail the advance of the Boeotians southwards. For example, Plutarch, in the Life of Cimon:

\footnotetext{
${ }^{124}$ Buck (1979), 77-78.

${ }^{125}$ HCT 1:118.
} 


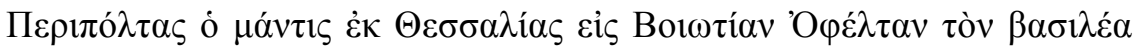

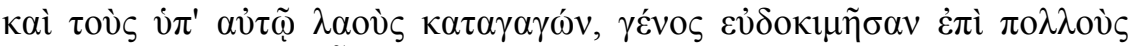

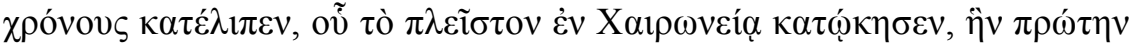

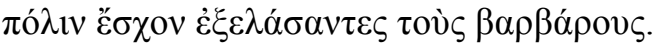

When Peripoltas, the seer, had led his king Opheltas and the hosts beneath him from Thessaly to Boeotia, he left his well-reputed race for a long time: the most part settled in Chaeronea, which polis they first occupied after they drove out the barbarians. (Cim. 1)

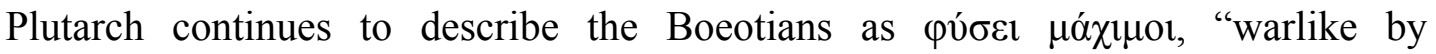
nature"; ${ }^{126}$ the depiction of the arriving Boeotians as $\lambda \alpha o v$, "(military) hosts", and their ejected opponents as $\beta \alpha \rho \beta \alpha ́$ óvৎ, "(enemy) foreigners", leaves little doubt that what Plutarch describes is a unified invasion. ${ }^{127}$ Buck's synthesis concludes that the invasion, only semi-mythical, of Boeotia was conducted in three stages, each several generations apart, "in an organized manner under one king ... not convincingly linked to any other royal house." 128 The stories are attractive but largely unverifiable, though there is archaeological evidence to support disruption consistent with an invasion in the Sub-Myceanean Period. ${ }^{129}$

The myth of the Boeotian migration is an aetiology. It explains the cultural links between Boeotia and Thessaly. The degree to which it reflects a historical migration is dubious, but the most important thing is that it depicts the Boeotians as a unified migrant body. Other sources imply the progress of the Boeotians across the central Greek basins which became their home, but as Kowalzig notes, the invasive force largely dissipates south of the Copaiis. ${ }^{130}$ There is no explanation offered in any source for how the Boeotians came to be politically divided; the myths of Boeotian migration create a shared origin myth. Most noticeably, the classical forms of the

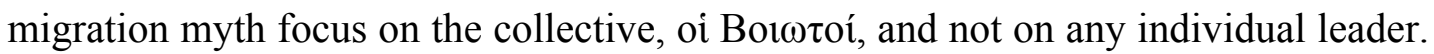
The migration is therefore presented in the discourse as the history of the same group which cooperated in the Classical Period.

\footnotetext{
${ }^{126}$ See Rockwell (2008), 10, on the Boeotian military reputation, with a list of references in Classical authors (n. 26).

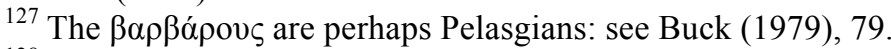

${ }^{128}$ Buck (1979), 75-84, esp. 81.

${ }^{129}$ Buck (1979), 80; Fossey (1988, 424-27), places the arrival of the Boeotians earlier, by LHIIIB (before the Trojan War), with archaeological evidence for a small influx of new population at Thebes (cf. Desborough [1964], 121-22), although not enough to reverse the downwards trend of habitation sites; Schachter (1996), 8-12. Andreiomenou (1989), 253, argues that the decline seen in Boeotia in the Sub-Mycenaean is one of evidence known to modern scholars, and not of ancient production.

${ }^{130}$ Kowalzig (2007), 358.
} 


\section{b. The Boeotians in the Iliad}

While the Homeric epics should constitute the earliest texts which appeal to Boeotian ethnic identity, the matters of dating, composition and transmission are so problematic as to make it impossible to securely employ the Iliad's depiction of Boeotians as evidence of Boeotians in the Bronze Age or at the time of composition. Homer and Hellanicus contradict each other on the basic point of the Boeotians' homeland at the time of the Trojan War. I focus here on how the depiction in the Iliad contributes to the discourse of united Boeotian identity. The Boeotians are thoroughly unimportant in the Homeric epics. But they are present in the Iliad, though they provide no major characters and their military efforts are contained to a few brief scenes in the fighting before Patroclus' return to battle. They do not appear at all in the Odyssey. ${ }^{131}$ The Iliad's Boeotians are generally depicted as a monolithic group.

The earliest and most substantial mention of the Boeotians in the Iliad is in the "Catalogue of Ships" (2.484-759). ${ }^{132}$ The Boeotians are the very first contingent described; Homer lists five generals, twenty-nine locales and assigns 50 ships $\times 120$ men (6000 in total): ${ }^{133}$

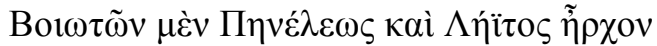

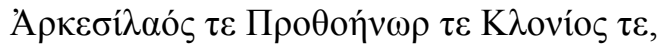

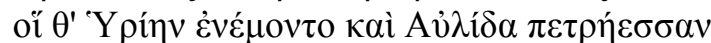

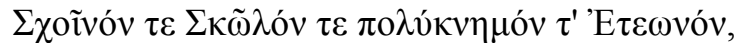

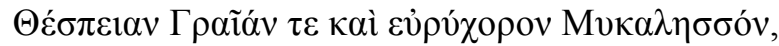

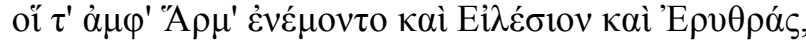

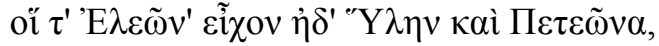

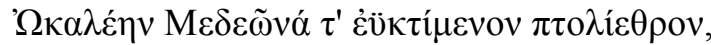

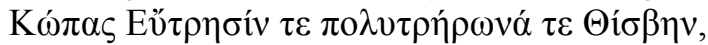

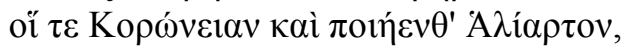

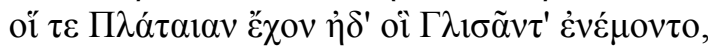

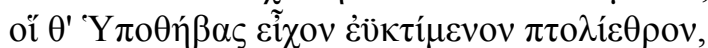

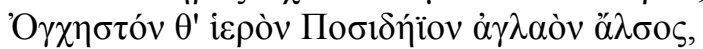

\footnotetext{
131 A few Cadmean Thebans appear, notably Epicasta (= Jocasta, Oedipus' wife, Od. 11.276) and Teiresias (Od. 10-12 passim).

132 The prime position of the Boeotians in the "Catalogue" is incongruous but not strictly relevant here. The "Catalogue" may be adapted from an earlier, independent work which described the assembly of the Greek fleet at Aulis in Boeotia, which would provide a motive for Boeotian prominence; the Catalogue may also be a Boeotian genre: Kirk (1985), 178-79 (or epic as a whole: Pavese [1998], 82), although the arguments for this are largely circular. West (1988), 168-69, attributes the "Catalogue" to Euboean poetic tradition.

${ }^{133}$ Hansen (1995b), 30, counts thirty-two locales without explanation; he has perhaps haphazardly included the three generals of 2.495 as locales.
} 


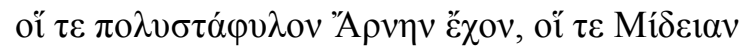

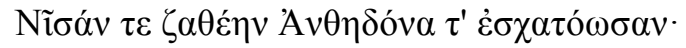

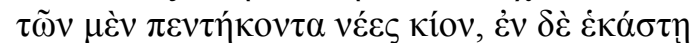

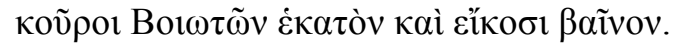

Peneleos and Leïtus led the Boeotians, Arcesilaus and Prothoënor and Clonius too: those who dwelt in Hyria and rocky Aulis, and Schoenus and Scholus and many-ridged Eteonus, Thespeia and Graea and spacious Mycalessus, and those who dwelt around Harma and Eilesius and Erythrae, and those who held Eleon and Hyle and Peteon, Ocalea, and Medeon the well-built city, Copae and Eutresis and Thisbe abounding in doves, and those two held Coronea and grassy Haliartus and those who held Plataea and those who dwelt in Glisas and those who held Hypothebae the well-built city and holy Onchestus the bright grove of Poseidon, and those who held many-vined Arne and those who held Mideia and holy Nisa and Anthedon on the edges - from these came fifty ships, and in each one, one hundred and twenty sons of Boeotians rode. (2.494-510)

There is no expansion on the names of the generals, except for the implication that Peneleos and Leïtus are perhaps more important that the other three, listed first and with the conjunction $\kappa \alpha$, which is perhaps more forceful than the repeated $\tau \varepsilon$ of 2.495. The lack of epithets, geneology or more specific local associations for the generals is unusual in the "Catalogue": most other entries give substantial information on the generals. By comparison the list of locales is much more prominent: nine of the twenty-nine locales receive epithets, while Onchestus and Hypothebae ("Lower Thebes") alone receive full-line descriptions (2.505-6). ${ }^{134}$ Larson suggests that the depiction of the Boeotians in the Iliad focuses more on the massed body than individuals: ${ }^{135}$ here at least the focus is on the home locales of the Boeotians. ${ }^{136}$ The "Catalogue", although lacking some prominent examples of Boeotian settlement, defines a wide group of settlements. This large number acknowledges the fractured state of Boeotia. However, the five leaders seem to

\footnotetext{
${ }^{134}$ Thebes itself is absent from the present-day of the Trojan War. The name 'Y $\pi 0 \theta \tilde{\eta} \beta \alpha$ is explained as a reference to the lower city; it is assumed that the Iliad is alluding here to the destruction of Thebes by the Epigoni before the Trojan War (referenced explicitly in Diomedes' genealogy, $I l$. 14.113-114). Ebbott (2010) argues that all the references to Thebes and Tydeus in the Iliad are intertextual references to the "Thebaid" tradition (if not the actual Thebaid), and therefore give a rather more substantial presence to Thebes than generally recognised.

${ }^{135}$ Larson (2007), 32.

${ }^{136}$ Pace Hall (2007b), 52, who suggests that the Boeotians do not have a fixed territoriality in Homer

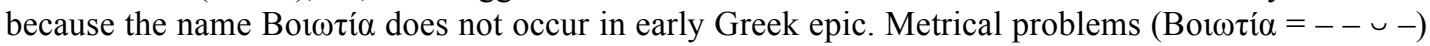
may in fact be to blame.
} 
command the Boeotians together, ${ }^{137}$ and Boeotian collective is the emphasis of the Iliad's depiction. The "Little Catalogue" of Book Thirteen (13.685-700) repeats the unity of the Boeotian force, which is listed among a small contingent of Achaeans from the northern areas. ${ }^{138}$

Individual Boeotians do appear occasionally throughout the Iliad. Peneleos is the most prominent character by far, and the only Boeotian to speak. ${ }^{139}$ In Book Fourteen, the Trojan Acamas kills the Boeotian Promachus, for which the Boeotian general Peneleos kills Ilioneus and makes a threatening speech to the Trojans (475-

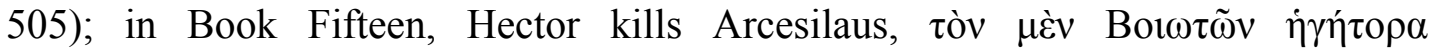
$\chi \alpha \lambda \kappa o \chi \imath \omega \dot{v \omega v}$ "that general of the bronze-armoured Boeotians" (15.330) and Clonius (340); in Book Seventeen, Boeotian generals Peneleos and Leïtus fight with Hector (597-606). In these three episodes, the generals rather than the wider Boeotian host are the focus. They are not developed either as characters, and the only details given, if any, link them to the wider Boeotian contribution. The Boeotian generals are the only Boeotian characters mentioned, with two exceptions: Promachus, mentioned above, and Oresbius, who appears nowhere else in any tradition. In Book Five, Hektor kills a handful of Achaeans, including:

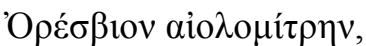

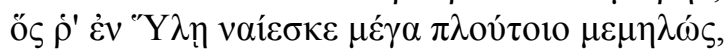

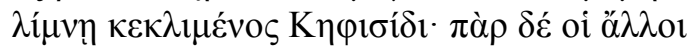

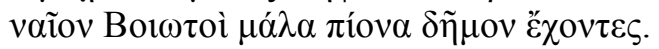

bright-mitred Oresbius, who lived in Hyle, tending his wealth carefully, on the edge of the Cephisian lake, and by him the other Boeotians dwelt, with a very rich land. (5.707-10)

The scholia on 708 suggest that he was a farmer, but his association here is clearly with Lake Copais (the "Cephisian Lake", i.e. the lake fed by the river Cephisus). The

\footnotetext{
${ }^{137}$ Buck (1979), 64, notes later associations of the individual generals with particular Boeotian sites, but these are very late (in Pausanias and Hyginus), and not always consistent. There is no sign of them as a conscious part of Archaic or Classical myth, and likewise no sign of divisions of the Boeotian body in the Iliad.

${ }^{138}$ Buck (1979), 65-66, argues that the arrangement of the forces in the "Little Catalogue" reflects pre-migration territories, i.e. that this part of the Iliad sees the Boeotians as still living in Thessaly. The order of the contingents, unlike the "Catalogue of Ships", does not seem ordered enough to clearly be interpreted as a geographic source, and the text perhaps slips between "Ionians" and "Athenians", which would leave Boeotia unoccupied.

${ }^{139}$ Peneleos, the first mentioned in the Catalogue and most prominent, appears in four episodes but is

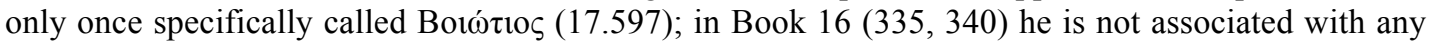
other Boeotian.
} 
toponym Hyle is mentioned as a Boeotian town in the "Catalogue of Ships" (2.500). ${ }^{140}$ However, Oresbius is not independent: like all the other Boeotians in the Iliad he is heavily associated with his fellow citizens, who have a $\pi$ íov $\alpha \tilde{\eta} \mu \mathrm{ov}$.

The depiction of Boeotians in the Iliad is inconsistent with later traditions on the occupation of Boeotia (except Thucydides, which, as I have dicsussed above, seems to be a reaction to the Iliad itself); it therefore should not be taken as an accurate description of the Boeotians before the Archaic Period. The only explanation which can sufficiently explain conflicting depictions is the possibility of homeostatic transformation: at some point, perhaps during the consolidation of the text of the Iliad at the end of the Archaic Age, but certainly during the Archaic Period, the text of the Boeotian entry was updated to reflect the current state of Boeotian occupation.

There is good evidence to suggest that this occurred elsewhere in the "Catalogue". The Athenian entry in particular presumes the synoecism of Attica (2.546-56), depicting Athens as the only city in the area. ${ }^{141}$ Although Greek mythology tended to place the unification of the nine Attic cities under Athens in the time of Theseus (perhaps a generation before the Trojan War), ${ }^{142}$ archaeological evidence suggests that synoecism did not occur in Attica until the early Archaic Period. ${ }^{143}$ If the "Catalogue" is based on a Bronze-Age model, it has been homeostatically transformed to reflect, if not the myth of Theseus (the leaders of the Athenian contingent are noteably not the sons of Theseus), then the unified state of Attica from the Archaic Period onwards. The Athenian entry emphasises the unified and unitary nature of the Athenian state. Likewise, the Boeotian entry seems to have been updated to reflect later political realities in terms of the area and occupation sites. Its depiction of the Boeotians as unified body who cooperated military should not be taken as evidence of Bronze Age ethnic identity, but it does clearly encourage the Archaic sense of solidarity.

\footnotetext{
${ }^{140}$ Zenodotus read ${ }^{~} \mathrm{Y} \delta \eta$ rather than ${ }^{\top} \mathrm{Y} \lambda \eta$, and Eustathius (ad loc.) suggested, based largely on the construction of Oresbius' name (ỏ $\varepsilon \varepsilon \sigma-+-\beta 10 \varsigma$, 'mountain-dweller'), that the text should be read as

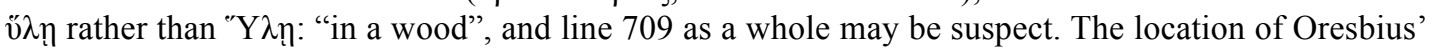
home is therefore somewhat dubious.

${ }^{141}$ Hope Simpson and Lazenby (1970), 56.

${ }^{142}$ E.g. Thuc. 2.15.1-2, Plut. Thes. 24.

${ }^{143}$ See Diamant (1982).
} 


\section{c. Minyans in the Iliad and Other Traditions}

The region of Boeotia is to some extent a natural area, delineated by high mountains to the south-east, west and north-west and by the sea to the north-east and southwest. Both Pausanias and Strabo dedicate discrete chapters to Boeotia in their geographies (Paus. 9; Strab. 9.2) ${ }^{144}$ It seems that the regional borders of Boeotia were well-defined; a few settlements did fall at various times on different sides of the border, but these were generally small and permanent shifts in the border. Oropus was the most wavering polis, either Boeotian or independent, depending (it seems) largely on the primacy of pro-Boeotian or pro-Athenian factions; but the city is not described as part of Attica. ${ }^{145}$ On the whole, then, the region defined the scope of the people as much as the people defined the region.

However, the "Catalogue of Ships" does not present a fully merged Boeotia: the Boeotians in the Iliad included, it seems, only the cities of the southern Boeotian basin, while two cities identified with sites in northern Boeotia receive a separate entry. It has generally been felt to preserve a depiction of prehistorical Boeotia which maintains recognises the separate ethnic identity of a group called Minyans who occupied the basin north of Lake Copaïs.

Directly after the Boeotian entry, the "Catalogue" moves on to a separate force, listing two contingents, two generals, and thirty ships:

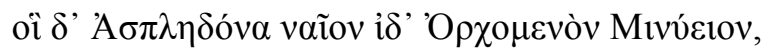

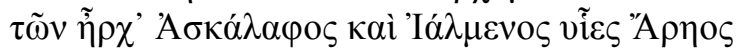

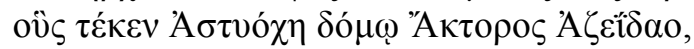

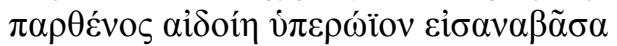

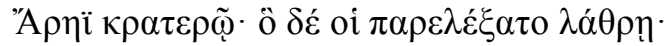

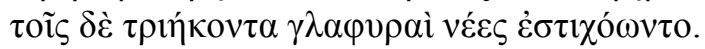

Those who dwelt in Aspledon and Minyan Orchomenus, Ascalaphus and Ialmenus led them, sons of Ares, whom Astyoche bore in the house of Actor the Azeid, the honoured maiden, after going into the upper house with mighty Ares, who lay with her in secret. With these thirty hollow ships sailed out. (2.511-16)

The separation of Orchomenus and Aspledon from the rest of later Boeotia has been read varyingly as a preservation of the Mycenaean glory of Orchomenus (perhaps

\footnotetext{
${ }^{144}$ Strabo does acknowledge (9.3.1) Orchomenus as a previously independent region.

${ }^{145}$ Part of Boeotia: Paus. 1.34.1; Attic dependency: Hdt. 6.101.1, Thuc. 2.23.3; independent region: Thuc. 4.99.1, 8.60.1; synoecised with Thebes in the early fourth century: Diod. 14.17.1-3.
} 
even diminished here), ${ }^{146}$ or as an affirmation of Orchomenian independence from the rest of Boeotia in the Archaic Period. ${ }^{147}$ The approach depends in no small part on positions regarding the composition of the "Catalogue", and is as insolvable as that problem. However, it should not be assumed that the independent Minyan cities are the natural sequel to the entry for the southern Boeotian basin. The "Catalogue" also describes regions to the east (Euboea) and south-west (Attica) of Boeotia, not to mention the diagonally neighbouring regions of Phocis and Locris. The poet had other options which would not necessarily have destroyed the internal narrative logic of the "Catalogue", and so it is significant that northern Boeotia is grouped tightly with southern Boeotia, and perhaps also that the distinct ethnonym Minyan is subsumed to (one of) the cities in question and not allowed to stand apart. ${ }^{148}$ The poem as it stands acknowledges the tradition of the Minyan cities' independence from Boeotia, but does little to assert it. The Minyans have even less presence in the Iliad than the Boeotians, but they are briefly mentioned in the Odyssey. ${ }^{149}$

Another minor myth seems to reflect Minyan independence from Boeotia, in which Heracles (or sometimes Oedipus) conducted a war with King Erginus of Orchomenus (Apoll. 2.4.11). ${ }^{150}$ Heracles freed Thebes from the domination of Erginus. The Theban victory resulted in Thebes imposing a tribute of two hundred oxen annually on Orchomenus, double the tribute which Erginus had imposed on Thebes originally. If this is a reflection of early disputes between Minyans and Boeotians, it is significant that Orchomenus and Thebes are the two cities at war. The earliest coins assigned to Orchomenus also followed an independent track, using local iconography rather than the regional iconography initially used on all other Boeotian coinage. ${ }^{151}$

\footnotetext{
${ }^{146}$ Kirk (1985), 198, although he notes that Il. 9.381 asserts the wealth of Orchomenus.

${ }^{147}$ Buck (1979), 97.

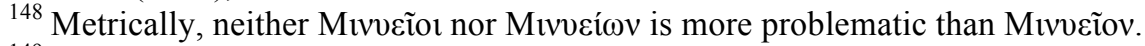

149 Only in the "Catalogue of Ships" in the Iliad; Od. 11.284, as part of Nestor's genealogy. The Minyan general Ascalaphus recurs (9.82, 13.478, 518, 526f., 15.112); Ialmenus only once, alongside Ascalaphus (9.82), but neither one is related to the Minyans outside the "Catalogue".

${ }^{150}$ Oedipus: Pherecydes, FGrH 3 F 95; Heracles: Diodorus 4.10; Strabo 9.414; Eustath. Ad Hom. 272; Theocritus 16.105. Buck (1979), 59, calls the fuller story, with Heracles rather than Oedipus, late, but it is referred to as early as Euripides (Her. 219-21).

${ }^{151}$ Kraay (1976), 110.
} 
The final, curious mention of the Boeotians within the Homeric "Catalogue of Ships" does seem to reflect part of the process of Boeotian unification, by involving the Minyans with Boeotians in the forces at Troy. At the end of the Phocian entry (the third in the poem, directly following the Boeotians and Minyans), there is a comment on the battle arrangements of the Phocians and Boeotians:

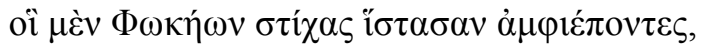

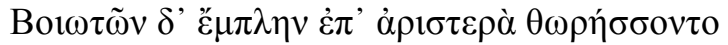

And the leaders marshalled the ranks of the Phocians, and they were armed along the left of the Boeotians. (2.517-526)

Kirk suggests only that the "Catalogue" is emphasising the connection of the Phocians and Boeotians as neighbours, ${ }^{152}$ but the political geography of the "Catalogue" placed the Minyans between the two contingents. There are very few mentions of battle order in the "Catalogue": three refer to the prominence of Agamemnon, Menelaus and Achilleus. The other notes that

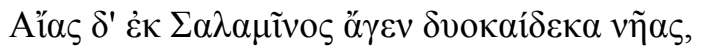

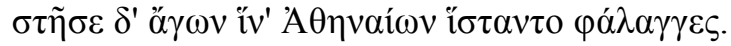

Out of Salamis Aias brought twelve ships and placed them next to where the Athenian battalions were drawn up. (2.557-58)

These lines have widely been suspected, since antiquity, of being an Athenian interpolation to establish their claims to Salamis as part of Attic territory. ${ }^{153}$ These lines featured heavily in the well-known dispute between Athens and Megara over the island of Salamis (Arist. Rhet. 1375b; Plut. Sol. 8-9): the Spartan judges chose this couplet over a pro-Megarian couplet to establish the rightful owner. Wickersham notes that the case is not a simple matter of textual criticism. ${ }^{154}$ The Spartan judges had no standard recension of Homer against which to compare the variants (a point rather telescoped in Aristotle's post-recension perspective); the judgment was not in fact on two lines but on two whole epichoric versions. ${ }^{155}$ The case does not depict the power of an appeal to the authority of Homer, but rather indicates the means of legitimising expansion through cultural expression. However, if one excursus on

\footnotetext{
${ }^{152}$ Kirk (1985), 200-1.

${ }^{153}$ Since Aristarchus, see Kirk (1985), 207-9.

${ }^{154}$ Wickersham (1991), 30.

${ }^{155}$ Why exactly the Spartans preferred Athens' claim is unknown; Kirk (1985), 208-9, dismisses the Megarian lines on the grounds that they do not structurally resemble the other entries in the Catalogue.
} 
battle arrangements is suspect, this casts suspicions on the other. Martin West has observed that the two lines at the end of the Phocian entry are easily read as an early interpolation for political statement on the part of the Boeotians, stretching beyond the usual conclusion of a contingent with the number of ships. ${ }^{156}$ West suggests that the propagandic material relates to the First Sacred War, although he offers no further explanation. Although the earliest mention of the First Sacred War is in Isocrates' invective Plataecus against Thebes, ${ }^{157}$ there is little reference to Boeotia's role in the War, ${ }^{158}$ and West offers no explanation for why the Boeotian-Phocian alliance should be enshrined in the "Catalogue". The statement closes a ring, however, around the first three entries of the "Catalogue", creating a section which is undoubtedly intended to be considered involved in "Project Boeotia". This section contains not only Boeotia and Phocis but the independently-minded Orchomenians. The section makes no overt claim to Orchomenus and Aspledon as members of the Boeotians, but the two northern cities are now implied to belong to a natural grouping. This brief interpolation undoes the effect of separating Minyans from Boeotians within the text.

Thebes was not necessarily responsible for the interjection on battle order. Indeed, this section does little to assert Thebes' position in Boeotia. But Thebes alone of the Boeotian poleis seems to have had the means to interfere with the text of the Iliad. No Boeotian polis seems to play any part in the city-texts of the Iliad. However, Herodotus reports a relationship between Thebes and the Peisistratid tyranny, roughly contemporary with other developments of a politicised ethnic identity in Boeotia, ${ }^{159}$ the same time at which Peisistratus (perhaps) was the patron of a new text of the Iliad. Larson has suggested that the Theban-Peisistratid relationship explains the prominence of Theban women in the Odyssey's "Catalogue of

\footnotetext{
${ }^{156}$ West (1999); see also West (2001), 178-79. West (2001), 11-13, suggests seven categories for minor early interpolations; Il. 2.525-26 falls into the first category: "[v]erses reflecting local or political interests that do not seem to be those of the original poet."

${ }^{157}$ Barring two allusions in the Homeric Hymn to Apollo (540-44) and the Shield of Heracles (47890): see Lehmann (1980), 245-56, Davies (1994).

${ }^{158}$ Isocrates associates the proposed destruction of Athens at the end of the Peloponnesian War (supported by Thebes) with the destruction of Crisa [sic: Cirrha] (Isoc. 14.31). This highly allusive reference is the only statement which highlights a Boeotian role in the war.

${ }^{159}$ Hdt. 1.61; cf. [Arist.] Ath. Pol. 15.2.
} 
Heroines". ${ }^{160}$ Nagy has argued persuasively that the stories of the Peisistratid involvement with the Homeric epics demonstrate that Peisistratus and his sons used the epics as political tools, drawing parallels between Peisistratus and the law-givers Lycurgus and Solon. ${ }^{161}$ It is possible that the Peisistratean Athenian city-text reflected Theban imperialist interests in the northern Boeotian basin which survived Hellenistic revisions of the text.

\section{d. The Eponymous Hero Boeotus}

The shared name is perhaps the most important constitutive element of an ethnic identity. For Greek ethnic identities this was embodied in the eponymous hero, who not only provided an aetiology for the collective name but also represented a shared history and, to some extent, a shared descent. In the case of the Boeotian eponymous hero Boeotus, the connection may have been more strongly felt because there was no

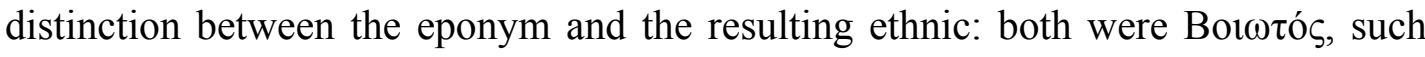
that any Boeotian referring to himself as Boeotian referred to Boeotus to do so.

Unfortunately, Boeotus is an entirely obscure character, and there does not ever seem to have been a canonical version of his myth. The profusion of variations is so great that it seems possible that there were multiple mythological characters named Boeotus, but no source acknowledges the possibility of multiple Boeotuses. ${ }^{162}$ The four sources which explicitly refer to him as the eponym of Boeotia or the Boeotian है $\theta v o \varsigma$ each offer a different version: in Hellanicus ( $F G r H 4 F 51)$ Boeotus is the son of Poseidon and Arne, and Boeotus the eponym of the territory Boeotia (previously called Aonia); in Diodorus Siculus (4.67.2-7) he is again son of Poseidon and Arne,

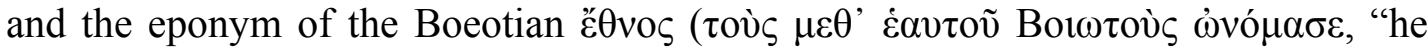
named his followers Boeotians", 4.67.2). Here, Diodorus makes it clear that he gave his name only to the people, and did so before the migration to Boeotia proper:

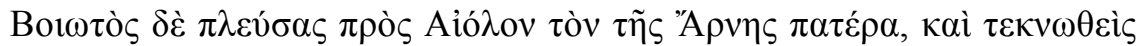

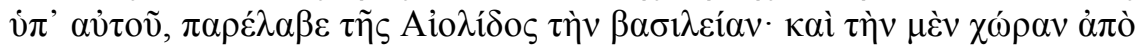

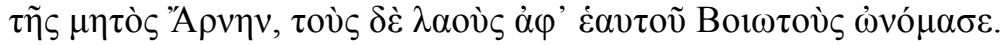

\footnotetext{
${ }^{160}$ Larson (2000), 218-21.

${ }^{161}$ Nagy (1996), 73-75.

${ }^{162}$ Diodorus Siculus' account at 4.67 manages to encompass most of the characters associated with Boeotus in a single account by including three different Aeoluses: Boeotus' brother, grandfather and great-great-great grandfather.
} 
Boeotus sailed to Aeolus, father of Arne, and was adopted by him. He took the rule of Aeolis [later renamed Thessaly], and he named the land Arne, after his mother, and the people Boeotians after himself. (4.67.6)

The name Arne for the Boeotian homeland matches Thucydides' account of the migration. Moreover, Diodorus carries on to link Boeotus to the five Boeotian leaders of the Iliad, his great-grandsons (4.67.6). At no point does he make reference to the Boeotian migration. However, in a much later chapter Diodorus describes an entirely different version, in which Boeotus is the eponym and even ruler of Boeotia proper:

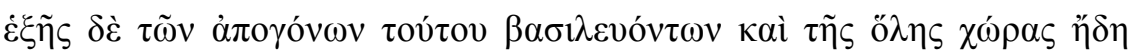

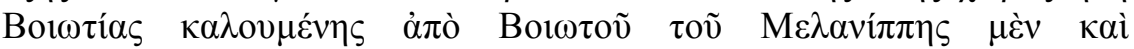

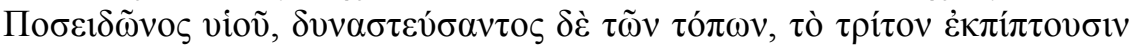

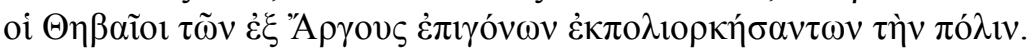

Thereafter, when the descendants of Polydorus [son of Cadmus] were kings and the whole land had already been called Boeotia after Boeotus, son of Melanippe and Poseidon, who was the ruler of the region, the Thebans were exiled for the third time when the "Epigonoi" from Argos took the city by siege. (19.53.6)

Pausanias presents a still different version, in which Boeotus is the eponym of the ¿ैقvos. This version makes him the son of Itonus (who is named as Boeotus' son in Diodorus, 4.67), who is associated with Thessaly; his name is nevertheless prominent as an (aetiological) etymology of Athenia Itonia, worshipped in a Panboeotian sactuary near Coronea:

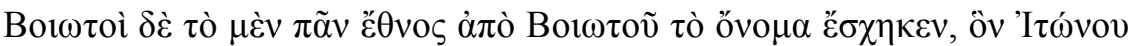

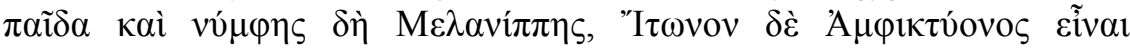
$\lambda \dot{\varepsilon} \gamma \mathrm{ov \sigma l...}$

As for the Boeotians, the entire $\ddot{\varepsilon} \theta v o \varsigma$ got their name from Boeotus, whom they say was the son of Itonus and the nymph Melanippe, and that Itonus was the son of Amphictyon. (9.1.1)

In general, there is very little that can be concluded from the four divergent traditions. In all but the second account in Diodorus Siculus, Boeotus' eponymy is related to the $\tilde{\varepsilon} \theta v o \varsigma$ rather than the territory of Boeotia proper; in all three cases the Boeotians seem to receive their name while still residing in their Thessalian ancestral homeland. The accounts here once again focus on the origins of the Boeotians as a unified people: even in Diodorus' unusual account at 19.53, the rule of the Cadmean 
line at Thebes is largely ignored; although it represents a quite distinct heritage for Thebes against all the other Boeotians, it is never problematised. ${ }^{163}$

It is worth considering how prevalent the tradition of Boeotus was in the Archaic period, at the apparent time of Boeotian ethnogenesis. The evidence for his existence within the pantheon of Greek heroes before the late fifth century is meagre. He is referred to only briefly in two short fragments assigned to the great Hesiodic genealogical work, the Catalogue of Women, with somewhat dubious authority, and two fragments of Corinna. A testimonium to Hesiod in Stephanus (Hes. fr. $219=$ Steph. Byz. 483.3) makes him the father of Onchestus, eponymous founder of the

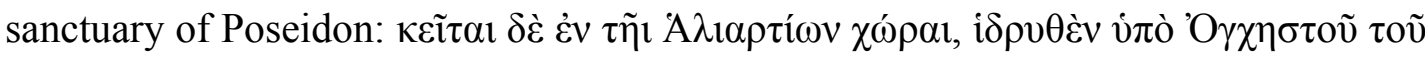

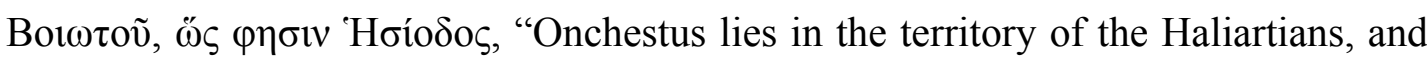
was founded by Onchestus, the son of Boeotus, as Hesiod says." A second testimonium of Hesiod makes Boeotus the colonist of Arne in Boeotia: ${ }^{164}$

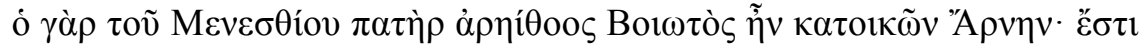

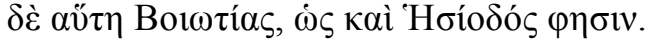

The father of Menesthius was war-swift Boeotus who colonised Arne: this is the Arne in Boeotus, as Hesiod also says. (fr. $218=\Sigma$ Hom. Il. 7.9)

These two references seem to associate Boeotus with two central Boeotian sites. The first testimonium is an exegesis of the Panboeotian sanctuary of Onchestus, mentioned in the Boeotian entry in the "Catalogue of Ships", which was to become the capital of the Boeotian Confederation in 338. Arne was one of the many Boeotian sites mentioned in the "Catalogue of Ships"; its name clearly recalls the name of the Boeotian homeland referred to in both Thucydides and Diodorus. Bakhuizen has contended that the Boeotian site was a mythological grounding-point for the Boeotians, and that there was never actually an Arne in Boeotia. ${ }^{165}$

Although these two testimonia are presumed to refer to the Catalogue of Women, there is very little evidence by which we can clearly position it in that poem: most

\footnotetext{
${ }^{163}$ A very little evidence suggests that the Thebans considered themselves to be different from other Boeotians due to their Cadmean history. Pindar ( $f r$. 118) draws a link between himself, Cadmus and Theron, but compare this with Theban insistence upon the "common ancestral traditions of the Boeotians" in Thucydides.

164 The interpretation here follows Larson (2007), 41-48, who reinterprets the traditional

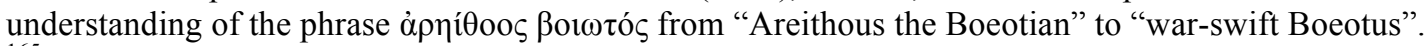

${ }^{165}$ Bakhuizen (1989), 65-66.
} 
notably, although many traditions of Boeotus' parentage makes him the son of Poseidon and a mortal woman, and therefore a suitable subject for the Catalogue of Women's enumeration of demigods, he is entirely absent from Apollodorus' Library, which often follows the Catalogue of Women's arrangement of genealogies, although perhaps not directly. ${ }^{166}$

One Corinna fragment draws the parental link between Boeotus and Poseidon: $\tau$ ov

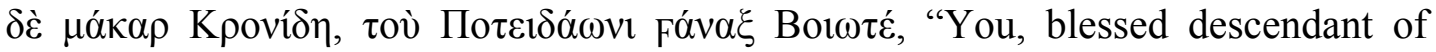
Cronus, you lord Boeotus, son of Poseidon" (fr. 5); this links Boeotus perhaps to the sanctuary of Poseidon at Onchestus. Boeotus reappears in two plays of Euripides, both centred around the myth of his birth, which here too is linked to Poseidon, although the fragments of Wise Melanippe and Melanippe Bound (frr. 480-513) suggest quite divergent myths. ${ }^{167}$ Most significantly, these stories make Boeotus twin brother to an Aeolus: placing the Boeotians within the Aeolian ethnic group, rather than providing a nucleus for shared Boeotian identity, may be part of the underlying focus of this myth. ${ }^{168}$

The sketchy remains of the Boeotus story suggest that he predated the Boeotian migration to Boeotia, although in another Corinna fragment he is reportedly identified as the father of Ogygus, the mythical first king of Thebes ( $\Sigma$ Apoll. Rhod. 3, 1077/87a). ${ }^{169}$ Perhaps most importantly, Boeotus was a unifying figure with no particular political associations (the relationship to Ogygus, so little attested, seems to be his only tie to a major Boeotian town); his relationships, in as much as they are identifiable in the Archaic and Classical Period, played up relationships between Boeotia and Thessaly. He is intimately linked with the sanctuary of Poseidon at Onchestus, one which was not tied to any particular Boeotian polis and later became the capital of the Boeotian confederation.

\footnotetext{
${ }^{166}$ West (1985), 32-35.

${ }^{167}$ Collard and Cropp (2008), 569-70.

168 The brothers do not seem to have been the focus of the plays, and they are certainly not focused on the Boeotians; Mellanippe Bound is set in Metapontus, not Boeotia. Boeotus is mentioned by name only once in the surviving fragments and testimonia, in Melanippe Bound, fr. 489.

${ }^{169}$ BNJ 328 F 91; see Buck (1979), 56 n. 12, on Pherecydes as a source for this tradition.
} 


\section{CONCLUSION}

Sources such as the Iliad provide an exemplar for regional cooperation in its use of ethnic names to describe cooperating groups. This cooperative aspect seems to have been a substantial feature of Archaic Boeotian ethnic discourse, in which the only noteable character was Boeotus, the eponym who was closely associated with Boeotian religion, but not with any particular Boeotian polis. Although the data-set is limited, it seems that Boeotian identity developed substantially in terms of the sense of solidarity over the course of the late Archaic Period, and was a highly functional feature of Boeotian society by the end of the Archaic Period, given the display of Boeotian identity in the works of Pindar and Corinna. This coincides, roughly, with the dates of the first known cooperative Boeotian acts (discussed in chapter two). On the whole the discourse lacks an aggressive assertion of leadership, but the discourse of unity in Homer can be linked to Thebes. Thebes' own discourse of its relationship to Boeotian states focused heavily on the ethnic identity which they shared. The construction of Boeotian identity is particularly important to remember in light of Hammond's assertion that relations between states should not be subject to the same standards of imperialism where there is a kinship relationship. This should not hold true if the discourse of kinship itself is a result of imperialist discourse. 


\section{2}

\section{ACCORDING TO ANCIENT CUSTOM: THEBAN HEGEMONY AND BOEOTIAN SYMMACHY}

The earliest demonstrably cooperative efforts of the Boeotians were military endeavours, which perhaps constituted a $\sigma v \mu \mu \alpha \chi i \alpha$. On a number of occasions beginning in the late sixth century the Boeotians worked together both to repel attacks against Boeotian territory and to attack other territories, including Plataea and Attica. Larsen and Buck have suggested that these cooperative efforts show that the Classically-attested Boeotian Confederation had its roots in the Archaic Period, but agreeing with Larson I argue that there is insufficient evidence of true confederate structures behind the military cooperation. ${ }^{170}$ Instead, I show that many of these expeditions were led by Thebes and resulted in the creation of a regional state system which recognised Thebes as the major power within Boeotia by the end of the Archaic Period. I argue that the state system, if not effective Theban dominance, persisted after the Persian War, and that after the Athenian occupation of Boeotia between 457 and 447, Thebes was able to use its hegemony to fill the space left by Athens, creating a Confederation based on the earlier $\sigma v \mu \mu \alpha \chi i \alpha$.

A confederation is, at its most basic form, a kind of super-state. ${ }^{171}$ The participating states ceded some part of their own sovereignty to the wider community (a practice which in some polemics is linked to a loss of autonomy). As a result each memberpolis of the confederation participated in two simultaneous governments, one local and one regional. Confederate government generally evolves from the local governments and balances the powers of the smaller and larger government. "Confederation" is therefore generally the more appropriate term for Classical Greek history than "federation", whereby smaller government devolves from the larger

\footnotetext{
${ }^{170}$ Larsen (1968); Buck (1979); contra, Larson (2007).

${ }^{171}$ The term "super-state" is not often used for Classical Greek history (except Cartledge [2000]); it is apt.
} 
government and the larger government is more powerful. ${ }^{172}$ The practical result of a confederation in the Greek world is therefore two co-existing $\pi 0 \lambda \iota \tau \varepsilon i \alpha$ of

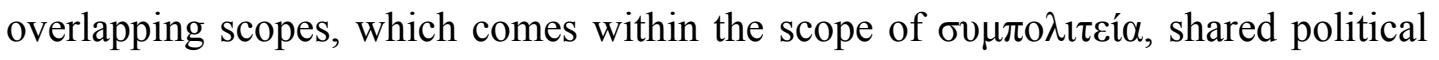
life. ${ }^{173}$ It is on this ground, of a clearly developped pan-Boeotian $\pi 0 \lambda ı \varepsilon \varepsilon i \alpha$, that we cannot talk about the Boeotian Confederation until after the Battle of Coronea in 447.

There are a number of instances of cooperation between Boeotian poleis in the late Archaic period. Thebes was at the forefront of these cooperative actions. However, there is little evidence from the Archaic Period to suggest that any Boeotian states ceded autonomy to the wider group, except in the case of Plataea. But, as I will argue, in the case of Plataea its autonomy was directly attacked, rather than ceded. However, a normalised system of relations between Boeotian states developed. Bull defines such a state system:

A society of states (or international society) exists when a group of states, conscious of certain common interests and common values, form a society in the sense that they conceive themselves to be bound by a common set of rules in their relations to one another, and share in the working of common institutions. ${ }^{174}$

The existence of state systems in the ancient world has been doubted, ${ }^{175}$ but is reaching growing acceptance. ${ }^{176}$ The rules of state system need not be formalised,

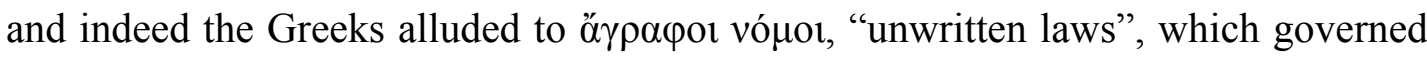
interstate relations. ${ }^{177}$ Attention has focused overwhelmingly on Panhellenic forms of state interaction, but regional systems must have developed too, and were essential to the formation of regional cooperations such as federations. Bauslaugh notes that the rules of a state system are rooted in "mutual respect born of shared culture": ${ }^{178}$ this must have been especially pertinent for small regions with cultural affinities such as Boeotia.

\footnotetext{
${ }^{172}$ Sordi (1994), 3, observes that this distinction is entirely modern.

${ }^{173}$ Sordi (1994), 4. $\Sigma v \mu \pi \mathrm{o} \lambda \iota \varepsilon \varepsilon i ́ \alpha$ can also describe merger of $\pi \mathrm{o} \lambda \iota \tau \varepsilon i ́ \alpha 1$. Giovannini (2003), 244-45, distinguishes $\sigma v \mu \pi \mathrm{o} \lambda \iota \tau \varepsilon i ́ \alpha$ as a feature of $\check{\varepsilon} \theta \mathrm{v} \eta$, as opposed to the full merger of poleis.

${ }^{174}$ Bull (1977), 13.

${ }^{175}$ E.g. Wight (1977), 50; Eckstein (2006), 37-78; see also discussion in Bederman (2001), 12, and the bibliography there.

${ }^{176}$ Low (2007), Bederman (2001).

${ }^{177}$ See Bederman (2001), 38-40, on the órpạor vó $\mu$ or.

${ }^{178}$ Bauslaugh (1991), 36.
} 
A state system is not necessarily a peaceful one. In fact, one of the features of the Panhellenic state system was a tendency towards conflict. Even in the early sixth century dedications at Olympia suggest that Boeotian states were still often in conflict with each other: one Theban dedication seems to record a victory over Hyettus, in northern Boeotia, another Orchomenus' victory over Coronea, another two record disputes between unknown opponents and Tanagra (one loss, one win). ${ }^{179}$ This is not an insignificant number of conflicts for a period when Boeotian history is largely unknown, and all date to the last half of sixth century. However, by the end of the Archaic Period, not long afterwards, it seems the Boeotian poleis tended to fight together against external enemies, and acknowledged the leadership of Thebes in doing so.

\section{EARLY COOPERATIVE (AND UNCOOPERATIVE) EFFORTS}

The Boeotians frequently fought on the same side. Without doubt, in the Classical Period, the most prominent aspect of the Boeotian Confederation was the combined Boeotian army. Other evidence shows that unity existed beyond military alliances.

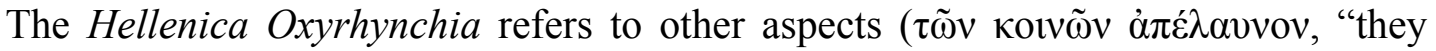
drew on the common resources", 16.4), which generally are not of interest to our militarily-focused historical narratives. This use of combined military forces dates back to at least the late sixth century. Such a form of military cooperation might normally be referred to as a loose league. However, in comparison with such cooperations as the Peloponnesian League, there was no formal written agreement in Boeotia to parallel the treaties between Sparta and its allies. Four separate conflicts of the late Archaic Period (between ca. 519 and 479, though the evidence does not provide exact dating), discussed in this section, involved a group of combatants referred to in our sources as "Boeotians". As the records of these cooperative actions show, the relationship between Boeotian states was a matter of an unwritten code of international relations.

${ }^{179}$ SEG 28 427; see Schachter (1989), 80 and n. 31; (1996), 17. 
The Boeotian participation in the Trojan War was of course a military action, and apparently a cooperative one as well. ${ }^{180}$ Even the myths of Boeotian migration to their historical territory directly address the conflicts which Thucydides and Herodotus imply in the "ejection" of Boeotians from Thessaly and their arrival in Boeotia. Whether true or aetiological of later military cooperation, such stories attest the concept of a traditional cooperation of Boeotian military forces. The stories, in their focus on territorial conquest, are tied up with the ethnogenesis of the Boeotians, and do not recognise divisions of Boeotia except as they are subsumed within the expansion of the $\varepsilon \theta v o s$. In avoiding the idea of Boeotian society as divided, they avoid likewise any discussion of hegemony.

The earliest textual assertion of Theban leadership in Boeotia does occur within the epic tradition, though it is a later example. The Shield of Heracles depicts a Boeotian force participating in a military campaign under the command of Heracles' stepfather Amphitryon:

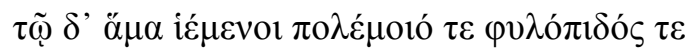

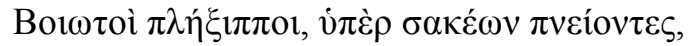

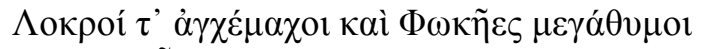

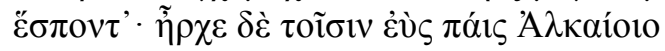
$\kappa v \delta$ เó

And along with him, bringing war and battle-din were the horse-driving Boeotians, panting over their shields, and the close-fighting Locrians and great-hearted Phocians followed: the noble son of Alcaeus [Amphitryon] led them, exulting in his host." ([Hes.] Asp. 23-27)

As in the Iliad, Boeotian forces are associated with the Phocians, although the Locrians are now added to this northern Greek alliance. As in the Iliad, the

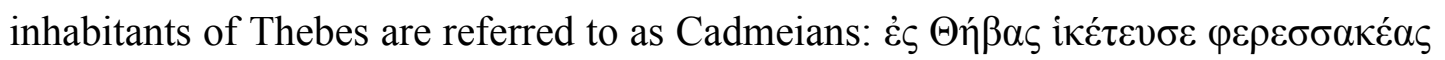
K $\alpha \delta \mu \varepsilon i ́ o v \varsigma$, "In Thebes he [Amphitryon] supplicated the shield-bearing Cadmeians." (Asp. 13). However, there is no clear distinction here between the two ethnics, although they are used only briefly. Nevertheless it is significant that the leader of the united Boeotians (and Locrians and Phocians) is depicted as an adoptive Theban. ${ }^{181}$ This expedition comes from the very early section of the poem, which we

\footnotetext{
${ }^{180}$ Cf. Hom. Il. 2.494-510; etc.: see pp. 32-40.

${ }^{181}$ For the Theban-ness of this all see Guillon (1963).
} 
are told was in fact a repurposed extract from the Catalogue of Women, ${ }^{182}$ and therefore from the seventh century, but the repurposing in the sixth century renders the entire section into a work which focuses on Boeotia. ${ }^{183}$

In this section, I will argue that Boeotia began to form a militarily-aligned in the late sixth century. Without any signs of formal agreements between Boeotian states, we must examine the attested cases in which the Boeotians fought together to ascertain the nature of the alliance. In each case, as I will show, the Thebans were clearly and prominently involved.

\section{a. Plataea, 519}

Several scholars have held that the earliest clear act of the Boeotian Confederation appears in the dispute between Plataea and Thebes in $519,{ }^{184}$ which resulted in the long-lasting alliance between Plataea and Athens. ${ }^{185}$ However, although both Herodotus and Thucydides give digressive accounts of the dispute (Herodotus in discussing the origins of the Plataean-Athenian alliance before the Battle of Marathon, 6.108; Thucydides in the debate between Thebans and Plataeans which followed the capitulation of Plataea in 427, 3.52-68), ${ }^{186}$ neither one contains any overt reference to the Boeotian Confederation. Herodotus' narrative perhaps has the Boeotians intervene for Thebes against Athens at the end of the dispute, but it is

\footnotetext{
${ }^{182}$ West (1985), 136.

${ }^{183}$ The Boeotian origins of the Shield are not uncontroversial: Guillon (1963) argues for a specifically Theban origin of the poem; combined with the rest of the Hesiodic corpus, the Shield has been used as evidence for a generally Boeotian substratum to the epic tradition (Page [1959]); Janko (1985), 182, argues for a Boeotian or even Theban origin; West (1985), 136-37, and Schachter (1989), 74, against.

${ }^{184}$ The date for this conflict is a point of minor contention: Thucydides (3.68.5) puts the date at 519, "93 years before" Plataea's surrender to the Thebans and Spartans in 427, but scholars after Grote (1907), 82 n. 4, have suggested 509 to be slightly more appropriate in our sketchy knowledge of Theban-Athenian relations of the period and to explain the presence of Cleomenes on the border between Boeotia and Attica: Moretti (1962), 105-7; Amit (1973), 71-73; Ducat (1973), 67-68; Badian (1989), 103 and n. 16. Shrimpton (1984) gives a thorough examination of the question (though he fails to discuss that the proposed corruption of Thucydides was not the unlikely ơ $\delta$ corruption is on the whole uncommon) and suggests 506 for this incident instead. HCT ad 3.68.5; Cloché (1952), 30; and Schachter (1989), 83, have preferred to maintain the reading of the MSS.

${ }^{185}$ Larsen (1968), 29; Amit (1973), 64, 66: "coinage is the sole evidence we possess that the League in fact existed prior to the episode"; Buck (1979), 107.

${ }^{186}$ Hammond (2000), 82, argues that Herodotus' account is based on Lacedaemonian eyewitnesses' reports. Thucydides perhaps follows Herodotus' account: Ducat (1973), 68.
} 
more likely that this is a rhetorical technique and that the conflict, if historical at all, reflects not the early stages of the Confederation, but of Theban construction of hegemony.

Herodotus begins his explanation with the aggression of Thebes which prompted Plataea to seek Spartan and then (on the advice, perhaps malicious, of the Spartan king Cleomenes) Athenian aid. An attempt at external arbitration was ultimately unsuccessful, and the Athenians finally defeated the Thebans in battle:

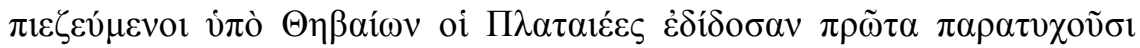

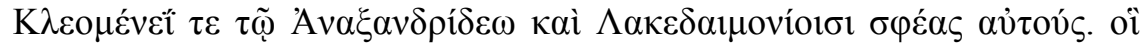

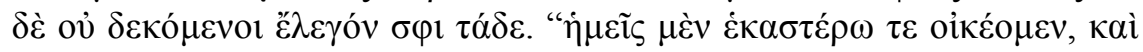

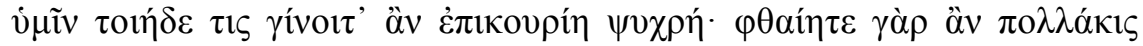

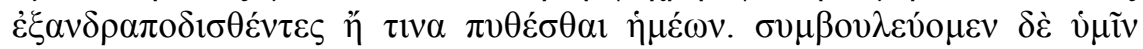

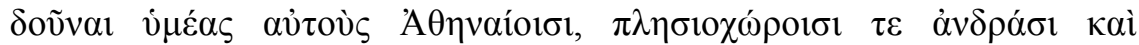

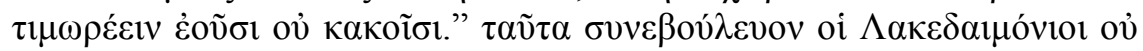

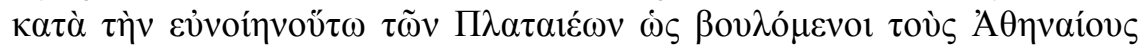

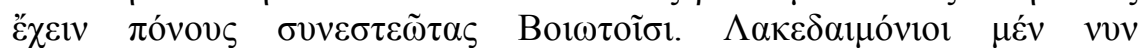

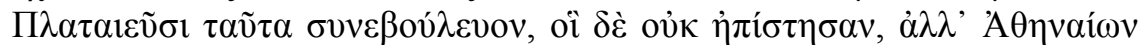

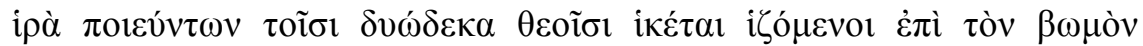

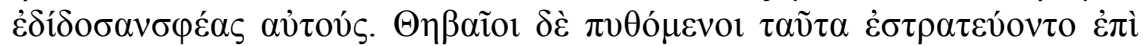

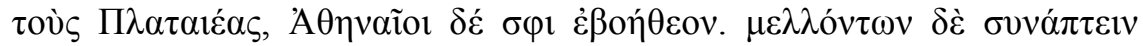

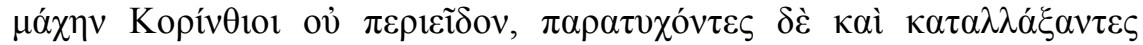

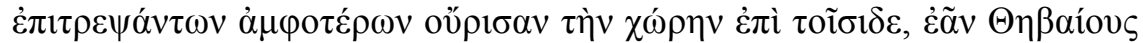

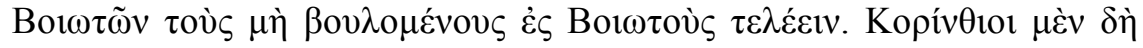

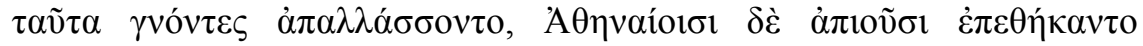

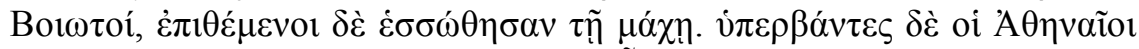

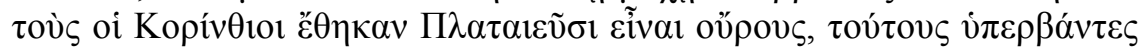

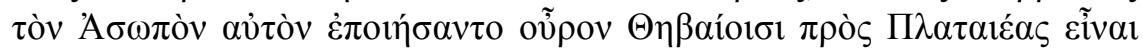
кaì 'Yoiás.

Under pressure from the Thebans, the Plataeans gave themselves up first to Cleomenes, son of Anaxandrides, and the Spartans, who happened to be near. They did not receive the Plataeans but told them this: "We live farther away, and to you any aid would be pointless; you might be enslaved many times in advance of us being informed of anything. We advise you to give yourselves up to the Athenians, men who live nearby and not bad for help." The Spartans advised this not out of good-will towards the Plataeans as much as in order that the Athenians have troubles stirred up with Boeotians. The Spartans advised as such to the Plataeans, and they did not mistrust them, but while the Athenians were worshipping the twelve gods they came as suppliant to the altar, giving themselves up. When the Thebans heard this they marched against the Plataeans, but the Athenians came to their aid. As they were about to engage in battle, the Corinthians did not stand aside: since they were there, they mediated between the two sides at their request, and decided their boundaries, allowing that the Thebans would suffer the unwilling Boeotians to not belong to the Boeotians. Once the Corinthians had decided this they set off, but the Boeotians attacked the Athenians as they were leaving, but were defeated in battle. Crossing the Asopus, the 
Athenians made it the border between the Thebans and Plataea and Hysiae. (6.108.2-6)

The only Boeotian states mentioned are Thebes and Plataea: the references in the discussion of Spartan motivations and Corinthian arbitration are generalisations and do not imply other Boeotians' involvement here. The only narrative reference to Boeotians therefore is in the Athenian retreat. It is difficult, therefore, to justify the claim that the conflict related to Plataean membership of an early Boeotian Confederation. Note that the Corinthian decision singles out the Thebans, and not the Boeotians as a whole. ${ }^{187}$

The substance of Thebes' aggression, which induced the Plataeans to seek outside aid, is unclear. As Amit rightly points out, the loss of some autonomy was not a point of concern given that the Plataeans offered themselves willingly to the Spartans and Athenians. ${ }^{188}$ Amit surveys the possible objections (ethnic, economic, or constitutional) and concludes that internal politics was at the heart of the matter. ${ }^{189}$ However, the suggestion that a group of pro-Theban Plataean aristocrats (like those who gave the city to Thebes in 431: Thuc. 2.2.2) aroused fears of oligarchic conspiracy in the general populace is not convincing: ${ }^{190}$ neither Herodotus nor Thucydides implies factionalism in Plataea at the time, nor suggests that the Thebans offered any enticement to the Plataeans. ${ }^{191}$ Moreover, the nature of the relationship between Athens and Plataea afterwards, which Badian identifies as

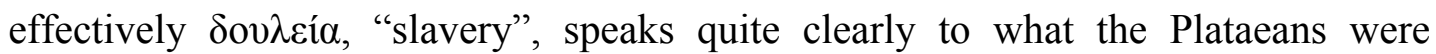
rejecting in fleeing Thebes: in Badian's words, “the Plataeans chose to become subjects of the Athenians, on whatever precise terms, in order to avoid becoming subjects of the Thebans, which at the time was the only real alternative." 192

\footnotetext{
${ }^{187}$ Hammond (2000), 80 .

${ }^{188}$ Amit (1973), 64.

${ }^{189}$ Amit (1973), 64-70.

${ }^{190}$ Amit (1973), 70.

${ }^{191}$ Cf. the conflict at the start of the Peloponnesian War (see pp. 78-93), which involved both Plataean cooperation and several attempts on Thebes' part to persuade the Plataeans to their view. Debnar (1996), 102, argues that the Thebans conceded at Thuc. 3.63.2 that the origins of the conflict were in their own aggression.

192 Badian (1989), 104; he goes on to argue (106-7) that Pausanias' famous oath to the Plataeans in 479 that they would "live autonomously" ever after in fact liberated the Plataeans from Athens, though they obviously maintained friendly relations. Hammond (1992), 144, argues for a gentler interpretation of the relationship, and refers to Thucydides' use of $\xi v \mu \mu \alpha \chi i \alpha$ for it $(3.55 .1 ; 2.73 .3)$. Ducat (1973), 67, notes that it was not unusual for a small city to "submit itself" to a more distant
} 
Herodotus' other uses of $\pi \mathfrak{\varepsilon} \zeta \zeta \omega$ make it clear that the pressure the Thebans placed upon the Plataeans was more likely a claim upon their territory: the action of $\pi \dot{\varepsilon} \zeta \omega$ is not simply to put political pressure on an opponent, but to tie up and claim resources, whether that is an important section of the opposing army $(9.61,63)$, cash and crop resources $(5.35,6.139,7.120,8.142)$, or land $(4.11,4.13,4.105,4.118,6.34) .{ }^{193}$ In many of the cases Herodotus describes, $\pi \imath \varepsilon \zeta o$ $\mu \varepsilon v o r$ are specifically those who face losing their land to expansionist encroachments. The fact that the Corinthians in their

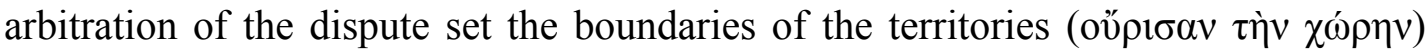
confirms that Thebes had occupied some of the territory of its neighbour. ${ }^{194}$ Finally the Athenians seem to have redefined the border to the Asopus, in a passage which clearly implies that this was favourable to the Plataeans. ${ }^{195}$ The implication that Athens went against the Corinthian arbitration suggests that Corinth was not completely unfavourable to Thebes in its original decision.

The Corinthian arbitration concludes that "the Thebans would suffer the unwilling Boeotians to not belong to the Boeotians". This is the only sentence in Herodotus'

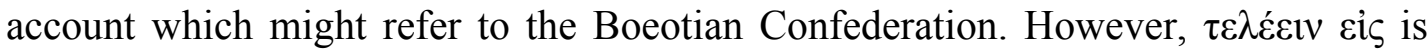
ambiguous: its literal meaning, "pay (tax) into", would indicate a formal participation in the Boeotian Confederation (and explain an economic connotation of

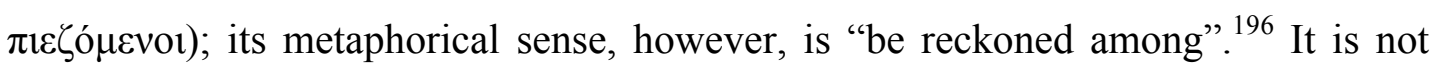
certain which sense Herodotus is using: his two other uses of the idiom $(6.53,2.51)$ are both metaphorical references to Hellenic ethnicity, not to formal participation,

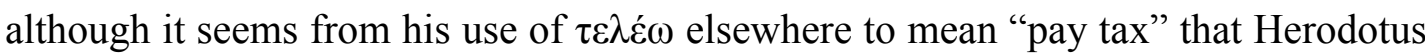

power, rather than suffer the domination of a nearby power, but Athens was not that distant, especially in comparison to Plataea's first choice, Sparta.

${ }^{193}$ The Nile runs low $(\pi \mathrm{\imath} \dot{\zeta} \xi \tau \tau \mathrm{l})$ in winter due to evaporation (2.25), the Scythians were forced $(\pi 1 \varepsilon \sigma \theta \varepsilon \dot{v} \tau \alpha \varsigma)$ into Cimmeria by Massagetae (4.11), and then the Cimmerians were forced ( $\pi 1 \varepsilon \zeta o \mu \varepsilon ́ v o v \varsigma)$ from their territory by Scythians (4.13), the Neuri from their land to that of the Budini

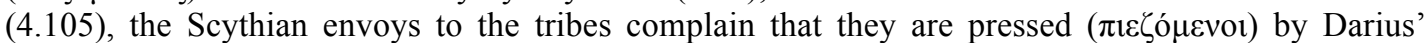
imperial ambitions (4.118), the cost of paying for his army prevented (غ่ $\pi \dot{\varepsilon} \varepsilon \zeta \varepsilon)$ Aristagoras from keeping his promise to Artaphernes (5.35), the Dolonci were being pillaged ( $\pi 1 \varepsilon \sigma \theta \varepsilon \dot{v} \tau \varepsilon \zeta)$ by the Apsinthi (6.34), the Lemnians suffered ( $\pi \varepsilon \varepsilon \zeta$ ó $\mu \varepsilon v o 1)$ famine and barrenness for killing Pelasgian settlers (6.139), the Abderans were pressed by the expense of hosting Xerxes (7.120), the Persian pillagings of Attica gain the Athenians Spartan sympathy as $\pi \imath \varepsilon \zeta$ ó $\mu \varepsilon v o 1$ (8.142), the Spartans were heavily pressed $(\pi \imath \varepsilon \zeta o \mu \varepsilon \dot{v} \eta v, \pi \imath \zeta \mathrm{o} \mu \varepsilon \dot{v} \omega v)$ by Persian assaults $(9.60,61)$ and the Greeks pressed the Persian forces hardest ( $\mu \alpha \dot{\lambda} \imath 1 \sigma \tau \alpha \ldots \dot{\varepsilon} \pi \dot{\varepsilon} \varepsilon \sigma \alpha v)$ around Mardonius (9.63).

194 Bonner and Smith (1945), 14, argue that Herodotus is mistaken in making the boundaries the material concern by which "the political question" was settled.

${ }^{195}$ Amit (1973), 78; Hammond (1992), 144.

${ }^{196}$ McQueen (2000), ad 53.1. 
could have been using the literal sense from which the metaphor developed. On the whole there is insufficient attestation of the Boeotian confederation in this period to support the assumption of a formal idea of membership.

Thucydides' Theban speaker likewise narrates the dispute with reference to a Boeotian nation, but not a formal Boeotian Confederation:

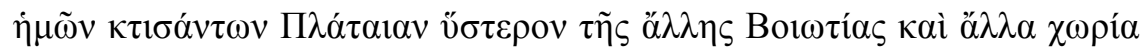

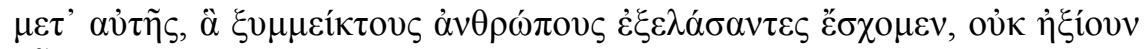

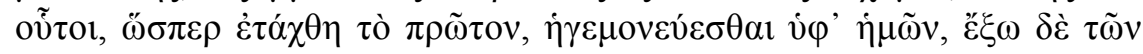

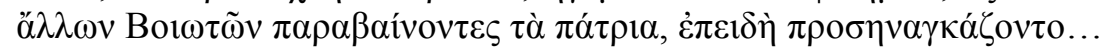

We occupied Plataea later than the rest of Boeotia ... but they did not acknowledge, as had been arranged earlier, that they were under our leadership, and they set themselves outside of the ancestral customs of the other Boeotians: then they were put under compulsion... (3.61.2)

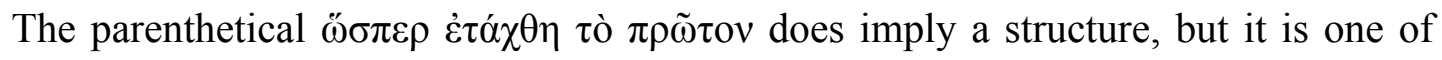

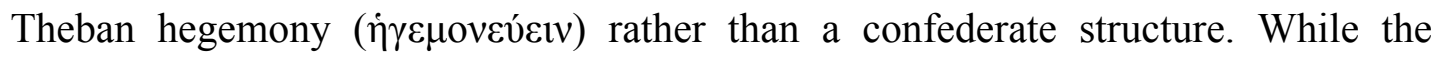
Theban speaker does associate the Plataean resistance to Thebes with a betrayal of Boeotian customs, it is important to note that he has already established a narrative in which Thebes is the founder of all Boeotian cities ( $\kappa \tau 1 \sigma \alpha ́ v \tau \omega \nu \ldots \dot{\eta} \mu \tilde{\omega} v)$, which both justifies Thebes' general leadership of Boeotia and gives it an implicit right to control Plataea through a sort of metropolis-colony relationship. The speaker is quite

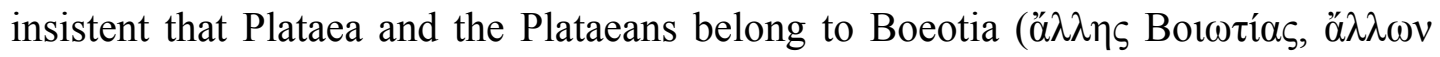
Boı $\omega \tau \tilde{\omega} v)$, but he does not phrase this within an enrolment metaphor like Herodotus.

The major concern of the dispute is not one of membership in the Boeotian Confederation, voluntary or involuntary: scholars have too willingly read Herodotus' $\tau \varepsilon \lambda \varepsilon ́ \varepsilon i v$ sis as a technical term for involvement in a formally constituted Confederation.

However, after the Corinthian arbitration, the arbitrators left, ${ }^{197}$ and according to

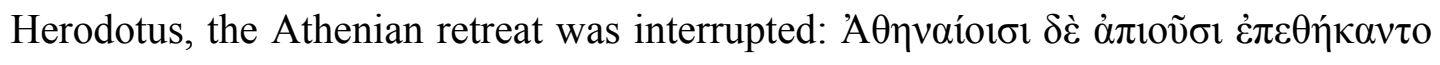

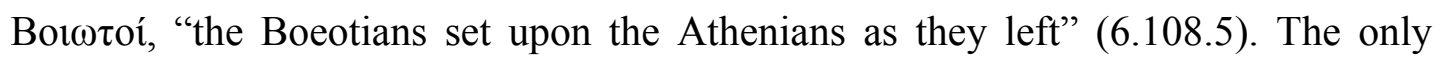
Boeotians mentioned in the preceding passage are the Thebans and the Plataeans themselves, the latter of whom cannot have attacked their benefactors (if nothing

${ }^{197}$ Or began to leave: Shrimpton (1984), 298. 
else, this would run contrary to the point of Herodotus' story, the ongoing alliance between Plataea and Athens). Buck explains the change of term by suggesting that a Boeotian cooperative army had been responsible for the pressuring of Plataea, ${ }^{198}$ but Herodotus earlier refers only to the Thebans, both as those pressuring Plataea and those who confronted the Athenians. Thucydides too focuses solely on a ThebanPlataean conflict. The reference to "Boeotians" must be to the discontented Thebans, perhaps as the leaders of an otherwise silent Boeotian force. ${ }^{199}$ By the late fifth century this was clearly felt to have been a Theban action, such as both Herodotus and Thucydides' Plataean and Theban speakers depict it. We might alternatively see this not as a reference to a wider Boeotian force but as an epithet for the Thebans.

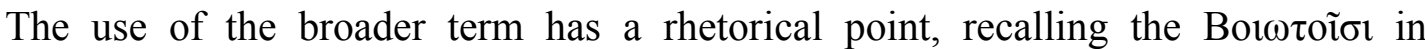
Herodotus' asserted motive for Cleomenes' advice and thus highlighting that Cleomenes has successfully manipulated the Athenians into a conflict with some (not the!) Boeotians, i.e. the Thebans. ${ }^{200}$ Herodotus' discussion achieves the overall point of explaining why the Plataeans stood with Athens in the battles of the Persian Wars, while the Boeotians (especially Thebes) stood on the Persian side.

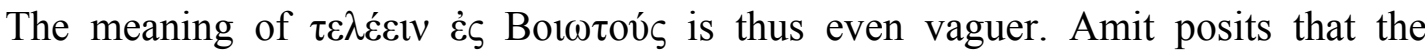
wording of the Corinthian decision demonstrates "that political grouping was still in the making". ${ }^{201}$ Note, by comparison, however, the use of $\sigma v v \tau \varepsilon \lambda \varepsilon \tilde{v} v$ in the Hellenica Oxyrhynchia's description of Thebes' dependent states under the Classical constitution (16.3). ${ }^{202}$ How and Wells gloss Herodotus' phrase as "to belong to the Boeotian league under Theban hegemony"; ${ }^{203}$ the Boeotian Confederation did not exist, nor was there any greater Boeotian force present here. We are left only with "to belong under Theban hegemony, as Boeotians did". The attack on Plataea,

\footnotetext{
${ }^{198}$ Buck (1979), 112; likewise Larsen (1968), 29, cautiously.

${ }^{199}$ Hammond's discussion $(2000,81)$.

${ }^{200}$ Plutarch attributes the reasoning to Herodotus' malicious imagination, for "if Herodotus is not malicious, then the Lacedaemonians are deceitful and malicious, and the Athenians foolish for being imposed upon, while the Plataeans were drawn into the middle not out of good will or respect, but as

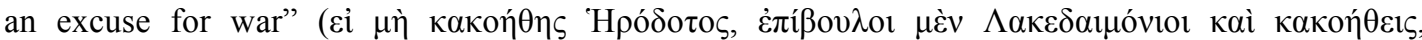

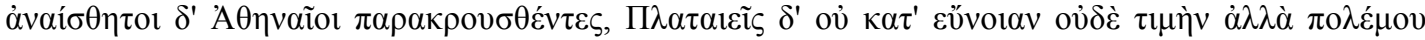

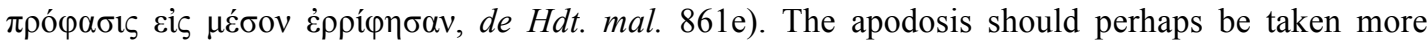
seriously than the protasis (see the introduction on Plut. de Hdt. mal.), in which case Plutarch is even more explicit about Cleomenes' manipulation as a $\pi \rho o ́ \varphi \alpha \sigma i \varsigma$.

${ }^{201}$ Amit (1971), 58.

${ }^{202}$ Hammond (2000), 85 and n. 20.

${ }^{203} \mathrm{CH} 2: 110$.
} 
probably in 519, was the first historical instance of a recurring dispute between Thebes and Plataea; all of our sources acknowledge Thebes (and Thebes alone) as the aggressor. Herodotus' use of "Boeotians" to refer to the force which attacked the retreating Athenians is a rhetorical point and not a historical one; there is therefore no real indication of Boeotian military cooperation here. Thebes' goal or goals for the attack are unclear. Substantial weight has been given to the Corinthian arbitration's statement regarding the Boeotians, but Herodotus also seems to refer to a disputed border between Thebes and Plataea, which may have been the more pressing concern.

\section{b. The Battle of Ceressus, c. $\mathbf{5 0 0}$}

Two late sources, Plutarch and Pausanias, know of a battle between Boeotians and Thessalians at Ceressus (near Thespiae) which is not elsewhere attested in Greek historiography:

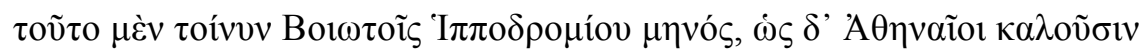

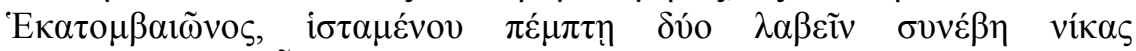

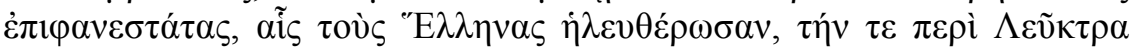

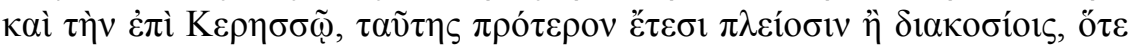

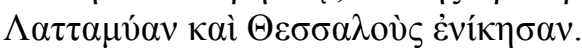

Similarly it happened that on the fifth day of the month Hippodromium, which the Athenians call Hecatombaeon, the Boeotians accomplished two victories by which they freed the Greeks: the one near Leuctra and the one at Ceressus, more than two hundred years earlier, when they defeated Lattamyas and the Thessalians. (Plut. Cam. 19.4)

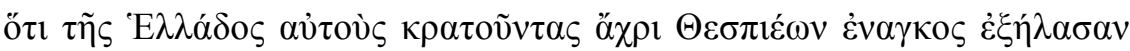

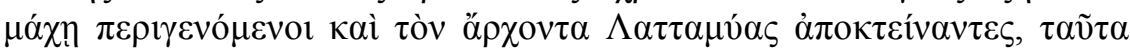

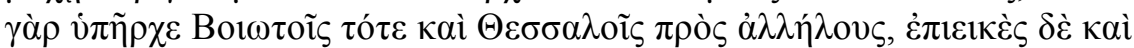

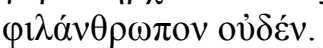

...because the Thebans had just recently driven them [the Thessalians] off in a battle as they were conquering Greece, and killed their leader Lattamyas, for thus were the Boeotians and Thessalians disposed to each other then: with no good-will or friendship. (Plut. De Hdt. mal. 866e-f)

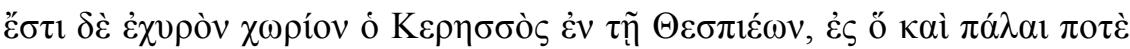

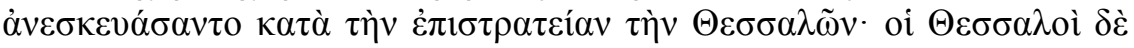

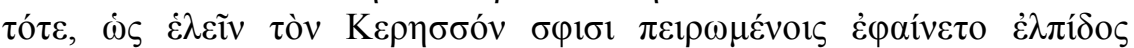

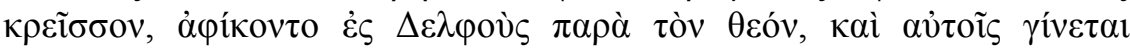

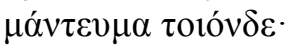

There is a secure spot, Ceressus, in the Thespians' land, in which they once arranged to meet the invasion of the Thessalians. On that occasion the Thessalians, when there seemed to be little hope of them managing to seize Ceressus, consulted the god at Delphi, and they received this 
prophecy: [that Ceressus would be impregnable until after Leuctra]. (Paus. 9.14.2-3)

The three versions vary substantially in their details: Plutarch dates the battle "more than two hundred years" before Leuctra (i.e. before 571: Cam.) or "soon before" Thermopylae (479: De Hdt. mal.), while Pausanias does not seem to have an exact date at all ("long ago"). ${ }^{204}$ Moreover, while Plutarch considers the battle enormously important, comparable to Leuctra, Pausanias' only point of interest is that the Thebans would later besiege the Thespians at Ceressus after Leuctra.

The Thessalians fought the Boeotians as a whole (Plut. Cam.), the Thebans (De Hdt. Mal.), or the Thespians (Paus.). ${ }^{205}$ Sordi argues that "a resistere ai Tessali a Ceresso, non sono i Beoti, nè tanto meno i Tebani, ma i Tespiesi." ${ }^{206}$ We can infer, however, that Pausanias was appealing to irony, contrasting Theban and Thespian cooperation at the first Battle of Ceressus with the Theban siege of Thespians at the second Battle. The forces which Plutarch describes as "Boeotian" consist most of all of the Thebans, and perhaps Thespians: On the Malice of Herodotus implies that it was a largely Theban effort; the comparisons with Leuctra in both Plutarch and Pausanias suggest likewise. ${ }^{207}$

Buck hangs his earliest date for the creation of the Boeotian Confederation on this battle. ${ }^{208}$ However, there is no clear evidence to be found here of a pan-Boeotian effort, nor of any lasting effect on the Boeotian poleis (apart from their continued freedom, as Plutarch emphasises in the Camillus).

The Battle of Ceressus provides the first example of a defensive action by "the Boeotians", against a Thessalian incursion. The late tradition gives an imprecise

\footnotetext{
${ }^{204}$ Schachter (1989), 81-82, suggests that Plutarch is following different sources in each work. Plutarch's source is perhaps Callisthenes' Hellenica, which in particular may have been Plutarch's main source on the Theban point-of-view of Leuctra: see Georgiádou (1996), esp. 79-81. A more simple solution for the dates revises the manuscript of Plut. Cam. from "two hundred years" to "one hundred years", which puts the terminus ante quem agreeably in the 470s in both of Plutarch's versions: see Buck (1979), 107-11, and Sordi (1993). Sordi (1993), 30-31, suggests a date much closer to Thermopylae, perhaps 484. The manuscripts of Plut. Cam. must also be corrected from

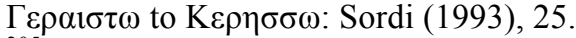

${ }^{205}$ It was certainly not the Thessalians with the Boeotians against the Thespians, pace Larsen (1968), 113: see Ducat (1973), 70.

${ }^{206}$ Sordi (1993), 27.

${ }^{207}$ Buck (1979), 110.

${ }^{208}$ Buck (1979), 107.
} 
date, but it seems likely that the conflict was close to or even between the Persian Wars. The degree of military cooperation is dubious; aside from Plutarch's ascription of the victory to the Boeotians, only Thespiae and Thebes are named, and not in the same sources. Pausanias may imply cooperation, but only very obliquely. Although Plutarch sees the Battle as enormously important, perhaps anachronistically, there is little sign of anything more than an ad hoc force.

\section{c. Attica, $\mathbf{5 0 6}$}

An unidentified force of Boeotians, working in cooperation with the forces of Chalcis, attempted to contribute to Cleomenes' third intervention into Attica (which, according to Herodotus, was more of an invasion than an intervention: cf. 5.76). An Athenian victory inscription, quoted by Herodotus (5.77) in his narrative of events and referred to by Pausanias (1.28.2), confirmed by the discovery of the inscription itself $\left(I G \mathrm{i}^{2}\right.$ 394), refers to the "Boeotian and [Euboean] Chalcidean races", $\theta^{\theta} \theta v \varepsilon \alpha$ Boı $\omega \tilde{\omega} v \kappa \alpha i ̀ ~ X \alpha \lambda \kappa \imath \delta \varepsilon ́ \omega v::^{209}$

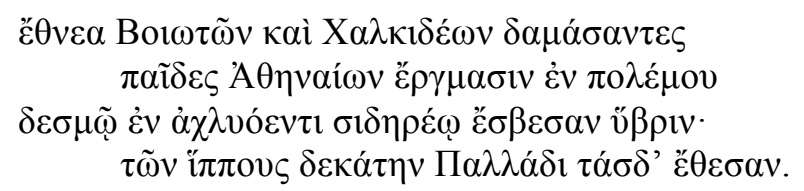

The children of the Athenians bound the Boeotian and Chalcidean races in grievous iron bonds by their deeds in war, and extinguished their outrage $[\tilde{v} \beta \rho ı c]$; this chariot they set up as a tithe from them to Pallas.

The Athenian inscription depicts their enemy in terms that undoubtedly exaggerate the scale of the conflict: whatever might be said of the Boeotians, the Chalcideans were hardly an $\ddot{\varepsilon} \theta v o s$ in themselves. We can likewise perhaps doubt the comprehensive representation of the Boeotians which the inscription claims. ${ }^{210}$ This inscription perhaps influenced Herodotus (for he claims to have seen it himself) to

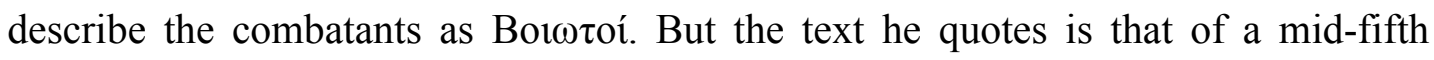
century copy, perhaps set up by Pericles to celebrate Athenian victory at Oenophyta. $^{211}$ The copy switched the two hexameter lines, emphasing the identity of

\footnotetext{
${ }^{209}$ ML 15B, the text of a mid-fifth century copy (seen by Herodotus); this copy transposed the first and third lines of the original $(15 \mathrm{~A})$.

${ }^{210}$ Pace Ducat (1973), 68-69.

${ }^{211}$ CH 2:43.
} 
the conquered (which rendered the old epigram more relevant to the fifth century) over the particular circumstances of Athenian revenge for the invasion. ${ }^{212}$

Hall finds a difficulty in the inscription in that, while the Boeotians are frequently referred to as an $\varepsilon^{\prime} \theta v o s$, the Chalcideans should properly be a polis: ${ }^{213}$ the elegiac inscription should not be taken as a source of precise information, but the composer could easily have written the metrically equivalent $\Theta \eta \beta \alpha i \omega v$ for Bot $\omega \tau \tilde{\omega} v$ if that was all that was meant: some larger contingent was involved, of which Thebes is the only identifiable member. ${ }^{214}$

Although Herodotus throughout the narrative of the war invasion refers to the Boeotians, his description of the aftermath of the invasion discusses only the Theban reaction: they consulted the Delphic Oracle in their desire for $\tau i$ or $\varsigma$ and received the advice that they needed support:

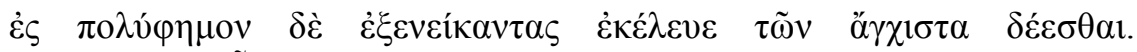

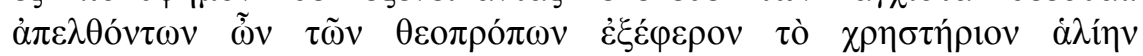

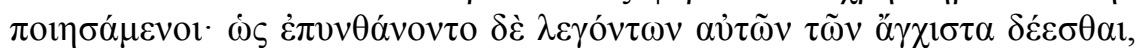

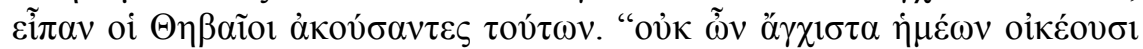

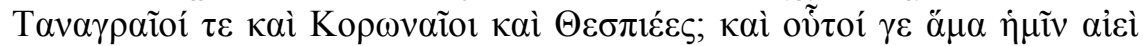

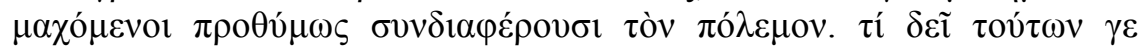
$\delta \varepsilon \dot{\varepsilon \sigma \theta \alpha \imath ; "}$

[The Pythia] bid them to take it to the many-voiced and entreat their nearest. When the envoys had returned they called an assembly and announced the oracle. When the Thebans heard them say they should ask the nearest, they said, 'Do not the Tanagrans and Coroneans and Thespians live nearest to us? And they always fight eagerly alongside us when they go to war. Why do we need to ask them?' (5.79)

This passage has often been interpreted out-of-context as depicting a standing alliance amongst the southern Boeotian poleis Thebes, Tanagra, Thespiae, and Coronea. ${ }^{215}$ In the context, however, it is curious to note that the Thebans clearly interpret $\alpha \gamma \chi \chi 1 \sigma \tau \alpha$ only in a spatial and not a temporal sense (those who fought with

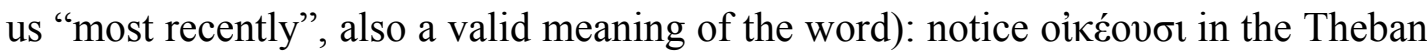
comment. Nor do they suggest that these cities might have their own interest in

\footnotetext{
${ }^{212}$ See discussion in ML, $15 \mathrm{~B}$.

${ }^{213}$ Hall (2007b), 50.

214 The alliance of Chalcis and Boeotia has left perhaps another, rather controversial, piece of evidence in the form of two coins (one from the Taranto Hoard) which bear, on one side the wheel symbol of Chalcidean coins and on the other the shield of Boeotians coins, cf. MacDonald (1987-88).

${ }^{215}$ Amit (1971), 58.
} 


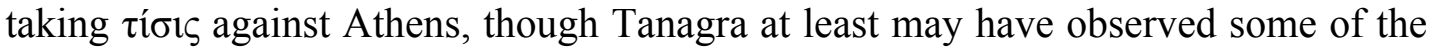
fighting between Boeotians, Chalcideans and Athenians at the Euripus. Amit notes as well that the oracle is reported only to an assembly [ $\dot{\alpha} \lambda \dot{\eta} \eta v]$, probably the general assembly of the Thebans, and not a federal council or magistrate. ${ }^{216}$ Here is good evidence to suggest, then, that these poleis were not involved in the original conflict; no Boeotian polis other than Thebes participated in the original invasion. ${ }^{217}$

The recent discovery at Thebes of a column with a partially-surviving inscription confirms the Thebans' participation. The inscription reads: ${ }^{218}$

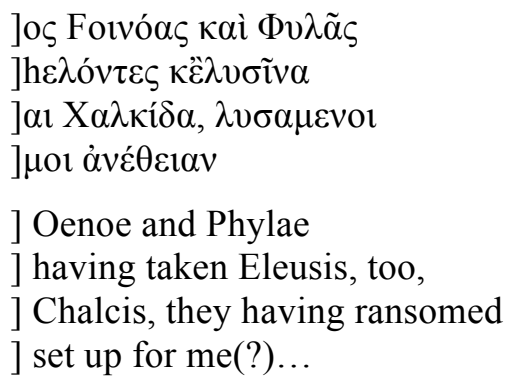

The column was found within the probable sanctuary zone of Thebes, north-west of the Cadmea. With its references to Oenoe, Eleusis and Chalcis, the inscription is most clearly read as a dedication following the conflicts of 507/6 BCE, although the surviving text has a reference to Phylae, unattested elsewhere, while not mentioning Herodotus' Hysiae (5.74.2). The Boeotian dialect evident in the digamma (line 1) and closed eta (for $[\mathrm{h}]$, line 2 ) indicates that this was most probably set up by Boeotians, but it is difficult to prove Aravantinos' assertion that it was established "more likely [by] Boeotoi" than Thebans alone. ${ }^{219} \Lambda v \sigma \alpha \mu \varepsilon v o r$ (line 3) is quite vague and the inscription provides little enough context to interpret it. Herodotus, however, states that 700 Boeotians and a substantial number of Chalcideans were captured in the course of the conflict and later ransomed back (whereby the $\delta \varepsilon \sigma \mu \tilde{\varphi}$ of the Athenian inscription). The inscription found outside Thebes may then commemorate

\footnotetext{
${ }^{216}$ Amit (1971), 58. Buck (1985), 27, argues ex silentio that this was a federal assembly, perhaps even the institution which was divided into four councils in the Classical constitution (see below).

${ }^{217}$ Schachter (1989), 81, suggests that a funerary epigram (IG vii 2247) from Thisbe of ca. 500 for a warrior who fell $\dot{\varepsilon} v \pi \rho o \mu \alpha \dot{\alpha} \chi 01 \varsigma$ "in the front lines" could refer to this battle, though there is not enough evidence to prove the association, nor a lack of other possible contexts.

${ }^{218}$ SEG 54518 = Aravantinos (2006). I have corrected Aravantinos' printing aì [sic] $\Phi v \lambda \tilde{\alpha} \xi ;$ the $\kappa$ is clear in the original inscription, and (as mentioned in the $S E G$ ) seems to be missing only through typographical error.

${ }^{219}$ Aravantinos (2006), 376.
} 
the act of ransom, perhaps as a thanks-offering from the returned soldiers. The location of the memorial, not in common Boeotian sanctuaries but at Thebes, speaks to the identity of the soldiers who offered it.

Cleomenes' failed expedition into Attica in 506 and the consequent Athenian reprisal against Boeotia and Chalcis are the first clear indications of Boeotian military cooperation in the Archaic Period. Epigraphic sources refer to the force as "Boeotians", but only the Thebans can be identified as a major participant. However, in the course of the aftermath the Thebans assert that their neighbours in Tanagra, Coronea and Thespiae did not need to be asked, for they would fight $\pi \rho 0 \theta v ́ \mu \omega \varsigma$, "eagerly", should the Thebans go to war. This is the earliest historical explanation of Boeotian cooperation.

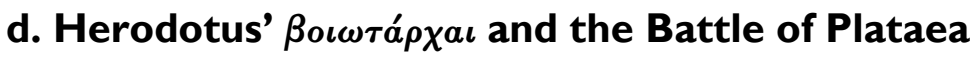

There are clear references to Boeotian military cooperation in the course of the Plataea campaign of the Second Persian War. Larsen suggested that although all the Boeotian poleis except Plataea and Thespiae Medised during the Persian invasions, each state did so on their own terms. ${ }^{220}$ I argue that this was not the case, and that the references to Thebes separate from the collective Boeotian states highlight Theban hegemony amongst the Boeotians. Herodotus frequently refers to the Boeotians collectively, particularly in his discussion of the Battle of Plataea, and even makes a singular reference to the formal title of Boeotian federal magistrates ( $\beta o t \omega \tau \alpha \dot{\rho} \rho \alpha \mathrm{l}$ ), otherwise unattested before the Peloponnesian War. I argue that this is an anachronism.

Herodotus gives the position of the Boeotians in the line at Plataea as a single group (9.31; excepting the Thespians and Plataeans who were on the opposing side), but he also admits that the description of the line was painted in broad strokes: $\tau \alpha \tilde{\tau} \tau \alpha \mu \grave{\varepsilon} v$

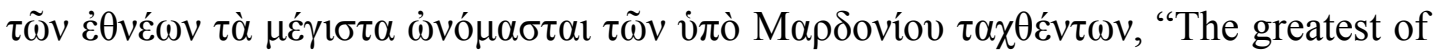
those nations commanded by Mardonius have been named" (9.32). ${ }^{221}$ Likewise, the

\footnotetext{
${ }^{220}$ Larsen (1968), 52; Amit (1971), 58-59, though he (incorrectly) asserts that "boeotarchs are never mentioned" during the Persian Wars.

221 'E $\theta v \varepsilon \alpha$ certainly does not have to be limited to the nations of the Persian Empire; the Medising Greeks quite validly divide into $\varepsilon^{\prime} \theta v \eta$.
} 
Spartans describe themselves as "experienced against the Boeotians and

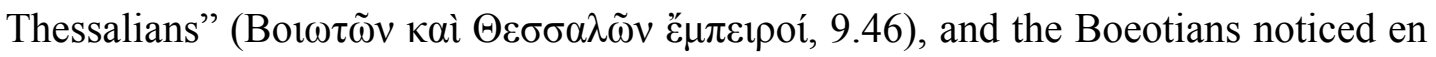
bloc that the Spartans and Athenians had switched their places on the wings of the Greek line (9.47). ${ }^{222}$ In the list of Greeks to give water and earth to the Persians, however, Thebes was separated from the Boeotians:

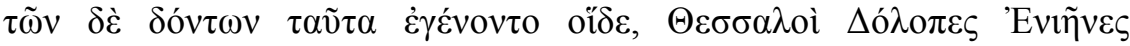

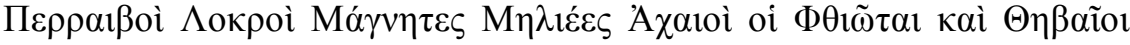

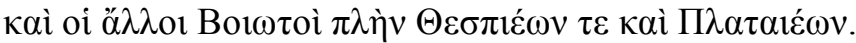

These were those who gave in: Thessalians, Dolopes, Enienes, Perrhaebians, Locrians, Magnetes, Melians, Achaeans, the Phthiotes and the Thebans and other Boeotians except Thespians and Plataeans. (7.132.1)

There is no clear reason why Thebes was the only polis singled out from the rest of the Boeotians. This might be ascribed to Herodotus' supposed bias against Thebes, but it seems equally possible that Thebes' Medism was in fact exceptional. It might equally suggest that the Boeotians followed the Thebans in giving earth and water.

Thebans are twice mentioned as advisors to Mardonius at Plataea, and as leaders (en bloc) of the Greek cavalry. ${ }^{223}$ Herodotus even implies that the Medising Thebans (here, as claimed in Thuc. 3.62.3-4, only a subset of the Thebans and not the entire polis) were the only Boeotians to fight:

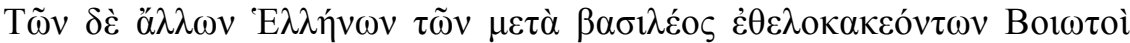

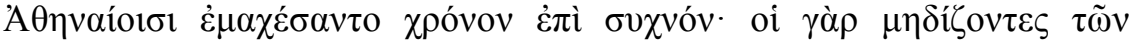

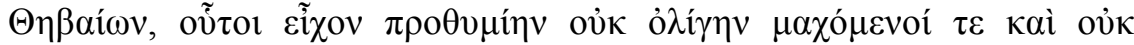

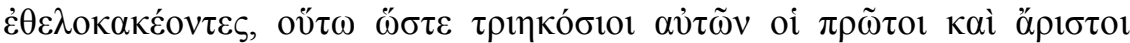

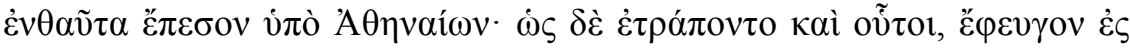
$\tau \grave{\alpha} \varsigma \Theta \hat{\beta} \beta \alpha \varsigma \ldots$

Although the other Greeks fighting for the King were deliberately fighting badly, the Boeotians fought for a very long time against the Athenians; for the Medisers amongst the Thebans had no small desire to fight and not deliberately fight badly, so therefore three hundred of the most prominent and best men fell there at the Athenians' hands. The rest turned and fled to Thebes... (9.67)

\footnotetext{
${ }^{222}$ How and Wells ( $\left.\mathrm{CH} 2: 308\right)$ are sceptical of the reality of this episode; it may have been an invention by Herodotus. We do not in fact know of any conflict between Boeotians and Spartans before the fourth century, although they had fought for the same cause in Cleomenes' expedition against Athens in 506, although on different fronts.

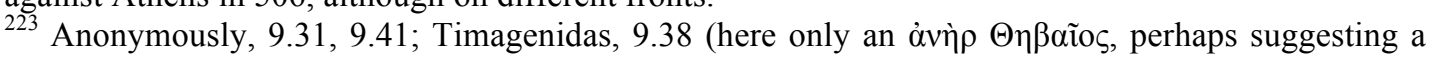
citizen in private capacity; at 9.68 where he is singled out as one of the most prominent Theban

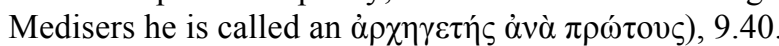


At the very least, the Theban contingent seems to have prevented other Boeotian contingents from leaving the battle, but Herodotus does nothing to distinguish the

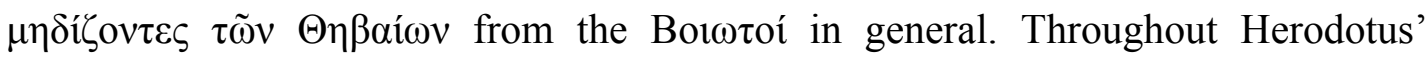
narrative of Plataea, only Theban or general Boeotian forces are mentioned (indeed, to the exclusion of all other Medising Greeks).

In fact there does not seem to be a distinction between Thebes and Boeotia as a whole during this campaign. This is made more clear in Timagenidas' speech during the siege of Thebes after Plataea. He proposes that Thebes should meet Athenian

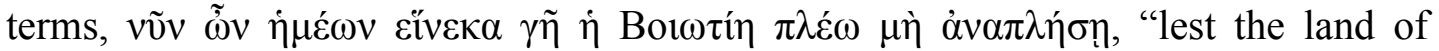
Boeotia suffer more now on our account." (9.86) The speech began with direct address to the ö $v \delta \rho \varepsilon \varsigma \Theta \eta \beta \alpha$ ĩot. It is clear then that the Theban oligarchy was in charge of its own contribution to the Persian invasion, but also held themselves responsible for Boeotia as a whole.

The only clear reference to a formal Boeotian federal constitution before the Peloponnesian War occurs here, in Book Nine of Herodotus. In describing the Persian retreat from Attica before the Battle of Plataea, he mentions that Mardonius was guided by locals sent by the Boeotarchs ( $\beta o 1 \omega \tau \alpha ́ \rho \chi \alpha \imath)$ :

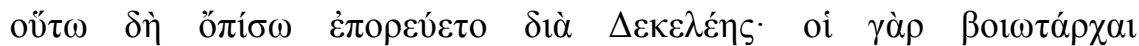

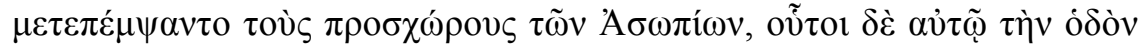

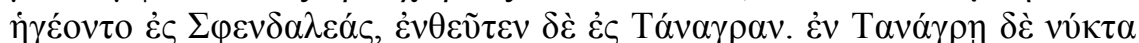

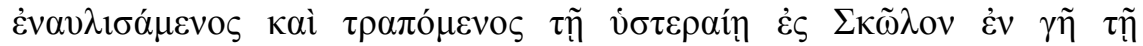
$\Theta \eta \beta \alpha i ́ \omega v \tilde{\eta} v$.

So he went back through Decelea; for the Boeotarchs had sent for their Asopian neighbours, and these men led him [Mardonius] along the way to Sphendaleae, and from there to Tanagra. He camped the night in Tanagra and on the next day turned to Scolus and was in Theban land. (9.15)

Herodotus makes no other mention of Boeotarchs specifically nor of any other Boeotian archon who represents more than one polis. In light of the dearth of any other information for a pan-Boeotian magistrate at the time of the Persian Wars, scholars have previously attempted to fill in the gaps with information about the 
later, Classical Boeotarch. ${ }^{224}$ More recently this has been superseded by doubts about Herodotus' use of the term here. ${ }^{225}$

It is worth considering what information the Herodotean passage and its context does provide. The route described takes the eastern path northward into Boeotia, circling around Mount Parnes: this significantly avoided a potential meeting with the amassed Greek forces marching north from the Isthmus (Hdt. 9.12, 9.15) The path taken was strategic (cf. Hdt. 9.13), and therefore not necessarily an indication that the guides or "Boeotarchs" involved were from the local poleis, Tanagra or Thebes. It was, however, the Thebans alone whom Herodotus depicted as encouraging Mardonius to make his stand in Boeotia in the first place (Hdt. 9.2), and after meeting resistance in Attica and Megara, he choose Thebes "in order to join battle

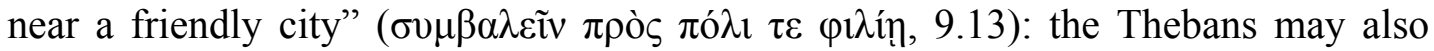
have offered to arrange the logistics of the retreat.

The somewhat curious term $\pi \rho \circ \chi \chi \omega ́ \rho o v \varsigma$ ("neighbouring people") is used only here in Herodotus. It cannot truly be said that the residents of the Asopus valley were neighbours to all possible Boeotarchs. It is a more common term amongst Hellenistic authors, but in two Classical authors it is used in a Boeotian context: $\mathrm{P}$ uses it specifically of the un-walled towns dependent on Thebes (Hell. Oxy. 17.4). ${ }^{226}$ It may therefore be used to direct our identification of the Boeotarchs towards Thebes.

The office of Boeotarch is clearly a significant feature of the later Boeotian Confederation: the Hellenica Oxyrhynica uses this office as the starting-point for its discussion of the representative nature of the constitution of the Confederation in the early fourth century, and Buck is almost certainly correct to suggest that the role needed no explanation for Herodotus' fifth-century audience. ${ }^{227}$ However, as Larson points out, it does not necessarily follow that Herodotus' mention of Boeotarchs here means that the office actually existed at the time of the Persian Wars. ${ }^{228}$

\footnotetext{
${ }^{224}$ See e.g. Flower and Marincola (2002), 125; Buck (1979), 124-25, 156-57; Larsen (1968, 31-32); ACT 1:239 (ad Thuc. 2.2.1).

${ }^{225}$ Morgan (2003), 22-23; Larson (2007), 172-73; contra: Roesch (1965), 95; Ducat (1973), 71, with little discussion; Salmon (1976), 18.

${ }^{226}$ Also in Sophocles, OT 1127; OC 493.

${ }^{227}$ Buck (1979), 124.

${ }^{228}$ Larson (2007), 173.
} 
Nevertheless, many scholars including Buck have presumed to fill in the large gaps in Herodotus' use of the term here with details from the Constitution as described in Hellenica Oxyrhynchia $16 .{ }^{229}$ However, the events here pre-date any information regarding what the office entailed or how it was filled by 84 years, information which we might hope to receive from Herodotus if the role was actually developed during the Archaic Period. Herodotus' reliability here suffers from his tendency (in which he is hardly alone amongst Greeks) to treat constitutional matters as synchronistic.

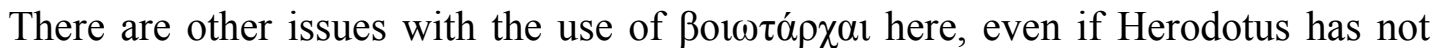
committed an anachronism. Under the constitution of 395, the non-Medising poleis Thespiae and Plataea were both responsible for electing Boeotarchs. ${ }^{230}$ These should presumably therefore be excluded from the college of Boeotarchs at this time, but Herodotus makes no such clarification. It seems more likely that the Boeotarchs mentioned were not all the chief magistrates of Boeotia, but magistrates from Thebes and/or Tanagra, as the term $\pi \rho \circ \sigma \chi \tilde{\omega} \rho 01$ suggests the rural communities of southern Boeotia. It is possible that Herodotus was not clear which city had provisioned the guides from the Asopus, and settled on Boeotarch as a compromise, albeit anachronistic. He would then mean here "magistrate from Boeotia" (or lower-case boeotarch), rather than a defined office.

Larson suggests that the office might denote an ad hoc role for the purposes of supporting the Persian retreat, or of organising defence of Boeotia against Greek forces during the Persian retreat. ${ }^{231}$ However, while there is clearly some cooperation between Medising Boeotian states at this time, it seems unlikely that any scrabbledtogether coordination resulted in the formal creation of an archon. ${ }^{232}$ It is possible that in the Archaic Period, as in $379,{ }^{233}$ Thebes created a magistracy which indicated its desire to expand control within Boeotia, but this requires a retrojection even further than that from the constitution of 395 to the Persian retreat.

\footnotetext{
${ }^{229}$ Roesch (1965), 95; Buck (1979), 123-138. Larsen (1968), 31, is more cautious.

${ }^{230}$ Plataea probably did not elect Boeotarchs in its own right: see pp. 83-84.

${ }^{231}$ Larson (2007), 173.

${ }^{232}$ Morgan's (2003), 202-5, suggestion of spontaneous armies arising in early ع̋ $\theta \mathrm{v} \eta$ works against, not for the reality of Persian War Boeotarchs.

${ }^{233}$ Larsen (1968), 176, allows for four Theban Boeotarchs in 379; Rzepka (2010), 115, argues that the seven conspirators of the Theban uprising of 379 (Xen. Hell. 5.4.2) may have been the Boeotarchs.
} 
Overall, the lack of evidence at this time for any of the federal structures which later accompanied the Boeotian Confederation along with the lack of evidence for the Boeotarch itself must reasonably lead to the conclusion that Herodotus is being anachronistic or imprecise, although perhaps for good reasons. However, on the whole it seems that Thebes was the state responsible, and that Thebes was the leader of Boeotia's policy of Medism in the Persian Wars.

I have argued here that the development of the Boeotian state system was led by Thebes. In the course of four major conflicts at the end of the Archaic Period, it is clear that Thebes was the major participant - in the cases of Plataea and Cleomenes' Attic campaign, perhaps the only identifiable participant. And yet these were all described at some point as efforts of the "Boeotians". This suggests a broader scope, in which Thebes used the term "Boeotian" increasingly to describe its own actions. Modern authors consistently under-emphasise Theban imperialism in the sixth century. Thus, Ducat acknowledges the existence of Archaic Theban imperialism, but sees this tempered by the comparative willingness of the other Boeotian poleis to form a union. ${ }^{234}$ Willingness is seldom clearly attested by the sources: Theban aggression clearly is, and it is Thebes' interaction with other Boeotian states which has left its strongest mark on the historiographic record. This attests most clearly to the forceful development of Theban hegemony within Boeotia by the time of the Persian Wars.

Schachter suggests that in fact Thucydides' "ancestral commonwealth of all the Boeotians" (3.65.2) referred specifically to the military unification of the Boeotians, an early stage which led to the formation of the Boeotian Confederation, and Schachter suggests that the Confederation functioned best militarily when under the leadership of Thebes. ${ }^{235}$ Military cooperation required, necessarily, a fairly high degree of coordination and/or leadership, and was a natural first step in the direction of the formalised inter-state system of a confederation. Ducat acknowledges that what he identifies as the Boeotian confederation at this time is "peut-être avant tout

\footnotetext{
234 Ducat (1973), 59.

235 Schachter (1996), 24.
} 
une symmachie", but agrees that military cooperation leads to other relationships. ${ }^{236}$ Thebes seems to have placed itself at the forefront of this military cooperation. It clearly asserted that it could call on several Boeotian poleis to fight for it so consistently that they did not need to be consulted, but there is equally no indication that this was a formal relationship of $\sigma v \mu \mu \alpha \chi^{\prime} \alpha$. This systematic cooperation was a forerunner to the prominent military aspect of the Classical Boeotian Confederation, which I will now discuss.

\section{THE FOUNDATION OF THE BOEOTIAN CONFEDERATION}

In the following section, I argue that it was the military leadership of Thebes within Boeotia which resulted in the development of a true Boeotian constitution, after the Battle of Coronea in 447. Larsen and Fowler, within the belief that the Boeotian Confederation dated to the sixth century, suggested that Tanagra replaced Thebes as leader of the Boeotians after the Persian War; this leadership was disrupted by Sparta's defeat of Athens at the Battle of Tanagra (457). ${ }^{237}$ The supposedly resumptive Theban hegemony, however, was interrupted by Athenian hegemony after the Battle of Oenophyta (also 457), and Buck has contended that Orchomenus, not Thebes, led the revolt against Athens which culminated in the Battle of Coronea (447) and therefore took the leading role the resultant Boeotian federal constitution.

However, there is no evidence for the traditional 447 foundation date of the bestattested, Classical form of the Boeotian Confederation. ${ }^{238}$ This is the date of the Battle of Coronea, at which the Boeotians defeated the Athenians and therefore ended the Athenian hegemony which had been imposed on Boeotia after the Battle of Oenophyta (457). ${ }^{239}$ While it is true that the broadly oligarchic principle which seems to have been fundamental to the constitution described in Hellenica Oxyrhynchia would have been inconsistent with the democracies established in most

\footnotetext{
${ }^{236}$ Ducat (1973), 71.

${ }^{237}$ Fowler (1957); Larsen (1960).

${ }^{238}$ As N. Hammond (2000), 83, notes, the Confederation "is likely to have been [operative] from 446 B.C." (emphasis mine).

239 "Hegemony" is the usual term for Athenian presence in Boeotia at this time: as Amit puts it (1971, 63), "Athens undertook to ensure the means of retaining her power without being obliged to occupy the country". Some sources refer, apparently with the same meaning, to the Battle of Lebadea.
} 
of Boeotia under Athenian hegemony, ${ }^{240}$ there is nothing to suggest that the Boeotian Confederation came into existence immediately after the Battle of Coronea. $^{241}$ Moreover, this was not the re-foundation of a structure which had existed before the Athenian hegemony, as some scholars have assumed. The evidence which Buck employed to suggest that Orchomenus led the revolt relies not only on these assumptions but a narrow reading of the historiographical evidence of the revolt. Buck's argument requires the reconstruction, ex silentio, of the rise of Thebes between 447 and 431, for as I discuss in the third chapter, Thebes was clearly in charge of Boeotia by the attack on Plataea.

\section{a. Sparta, Tanagra and Thebes, 457}

It is generally supposed that Thebes' power diminished in the aftermath of Boeotian Medism. Thebes was perhaps the most prominent Mediser in Greek memory of the Persian Wars, ${ }^{242}$ but this reputation is not entirely borne out by the facts of the Persian War, in which Thebes' most prominent acts of Medism were the surrender shortly before Thermopylae, and its participation (with almost all other Central and Northern Greek states) on the Persian side on the field at Plataea. ${ }^{243}$

The impression of a disgraced Thebes is perhaps greater than the reality. Diodorus is the first author to give a true impression of Thebes' misfortunes in 457:

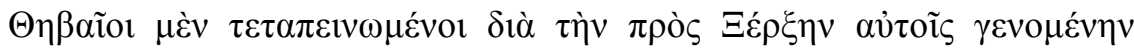

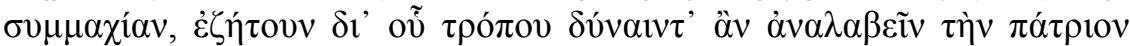

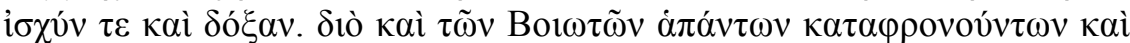

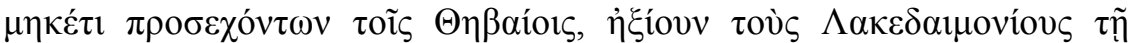

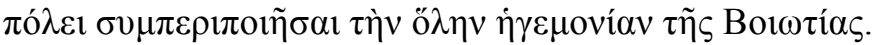

The Thebans were humbled by the alliance which they made with Xerxes, and the sought the means by which they might be able to reclaim their ancestral power and glory. Because of which, both because all the Boeotians looked down on them and no longer obeyed the Thebans, they asked the Lacedaemonians to help their city obtain the complete hegemony over Boeotia. (11.81.1-2)

\footnotetext{
${ }^{240}$ Buck (1985).

${ }^{241}$ Amit (1971), 53-54; pace ACT 1:184 (ad 1.113.3-4). On the Athenian-imposed democracies of the hegemony, see HCT 1:318; Larsen (1960), 17 n. 2; and discussion and bibliography in Amit (1971), 51-53.

${ }^{242}$ Demand (1982), 25-27.

${ }^{243}$ Hdt. 7.233; Thuc. 3.62.4.
} 
It should be noted firstly that Diodorus separates the disgrace of Medism from its problems in Boeotia, balancing the two issues with paired кaì. The Boeotian states were in general not in a position to condescend on the basis of Medism. Amit's discussion of the period concludes that there is no evidence for the reconstitution of the Boeotian Confederation before or after the Athenian hegemony, but this is founded on the presumption that the Confederation had existed in the sixth and early fifth century. ${ }^{244}$ Diodorus only refers to Thebes' desire to reassert its hegemony over Boeotia in the fifth century, a rare reference to Thebes' intent to control the rest of the region.

Larsen contends that the Spartans, aiming to help the Thebes reassert their dominance, were on their way from Phocis to attack Tanagra when they encountered and defeated an Athenian force. This relies on the assumption that Sparta had no other reason to be in southeastern Boeotia, for this was clearly not the natural route home from Phocis to the Peloponnese. It must be noted, however, that all other natural ways home through Boeotia, via the Isthmus, were likewise closed by the bloc of Athens, Plataea and Megara. Any number of reasons may have induced Sparta to seek a longer route home; Diodorus alone gives an indication of Spartan intentions at the time, and he does not relate these in any way to Tanagra.

Moreover, the Battle of Tanagra did not in fact involve any Boeotian states, although it seems to have concerned the matter of hegemony in Boeotia in the context of the First Peloponnesian War. The decisive battle here, however, was Oenophyta, only two months after the Battle of Tanagra. Thucydides says that the Athenians defeated the Boeotians (1.108.3). Tanagra was apparently singled out in the aftermath (according to Thucydides, its walls were torn down), but Diodorus Siculus seems to qualify this as only one of many aggressive actions which the Athenians undertook afterwards (11.82.5).

This is the only literary evidence to suggest Tanagran ambitions at this time, and the interpretation is founded on many presumptions: that Thebes' power had declined sharply after the Persian Wars, and that this decline left a power vacuum in Boeotia.

\footnotetext{
${ }^{244}$ Amit (1971). He finds no evidence for the dissolution of the Confederation after the Persian Wars either.
} 
Fowler has employed numismatic evidence in an attempt to support this discussion; in keeping with my own caution about numismatic evidence I discuss this interpretation separately, in chapter four.

\section{b. The Boeotian Revolt, 447}

It is not entirely clear that the circumstances of the Boeotian revolt of 447 provide evidence towards the circumstances of the foundation of the Confederation. ${ }^{245}$ Larsen contends that Orchomenus, and not Thebes, took the primary role in the revolt, and therefore was the major power involved in the foundation (or refoundation, as he would suggest) of the Confederation. The only detailed source is Thucydides: $:^{246}$

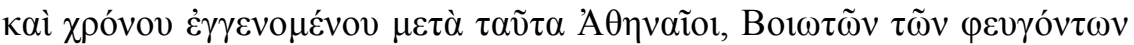

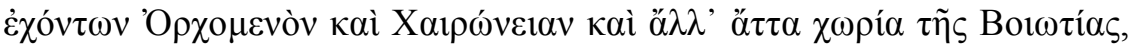

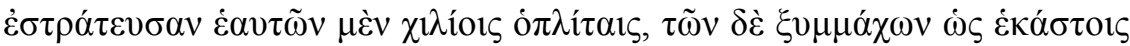

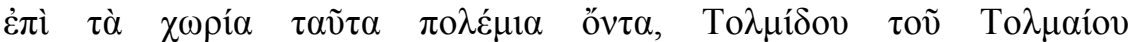

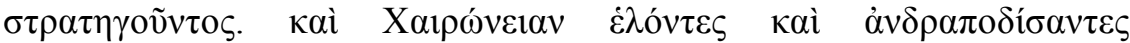

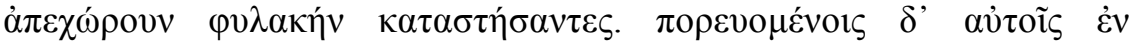

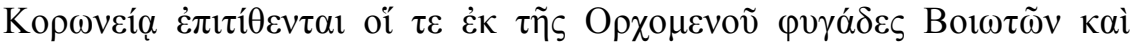

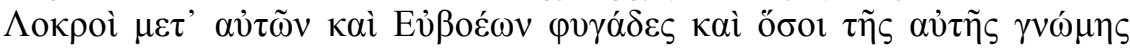

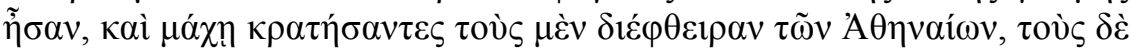

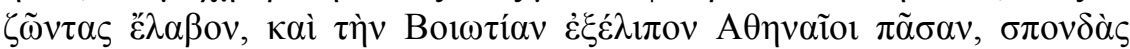

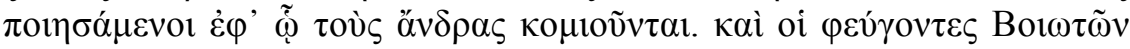

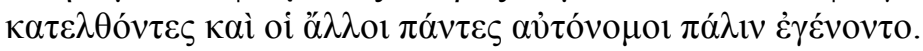

And sometime after that, with the Boeotians in exile holding Orchomenus and Chaeronea and some other regions of Boeotia, the Athenians attacked the regions which were hostile with a thousand of their own hoplites, with contingents from the allies, under the command of Tolmides son of Tolmaeus. They took Chaeronea, enslaved the population, established a garrison and left. As they were marching, the Boeotian exiles out of Orchomenus, and the Locrians and Euboean exiles and whoever was likewise inclined, attacked them at Coronea. They won the battle, killing some of the Athenians and taking others alive, and the Athenians left Boeotia completely after they made treaties for the return of their men. After that the Boeotians who were in exile returned and along with the others were all autonomous again. (1.113)

It should be noted first of all that later sources on the Battle of Coronea remember a substantial conflict: Xenophon's Pericles remembers it as one of the two battles which changed the Boeotians' attitude towards Athens (along with Delium, 424:

\footnotetext{
${ }^{245}$ Cartledge (2000), 403.

${ }^{246}$ Diodorus (12.6) adds nothing to Thucydides' account; Plutarch (Pel. 18) only a brief anecdote which highlights Pericles' prudence in comparison with Tolmides.
} 
Xen. Mem. 3.5.4), while Plutarch suggests that the Athenian force was unusually large due to Tolmides' enthusiasm, but still suffered a substantial defeat (Plut. Per. 18.2-3). Attica and Boeotia were approximately equal in population; the citizens of one Boeotian city, even with some exiles, would not have been a substantial force compared to Athens. Even before Leuctra and the floruit of Epaminondas' generalship at Thebes, its independence from the Boeotian Confederation was secured by a Spartan garrison and not home forces. It seems unlikely that Orchomenus could have defeated Tolmides' force so aggressively on its own.

Larsen contends that the lack of explicit mention here suggests that the Thebans did not aid their fellow Boeotians in the revolt, although they were already free from Athenian domination. ${ }^{247}$ According to Aristotle, the Thebans rejected the democratic constitution imposed by the Athenians:

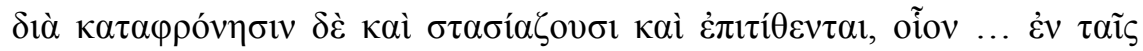

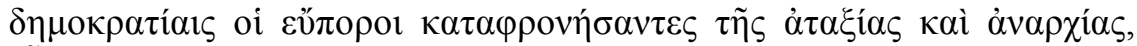

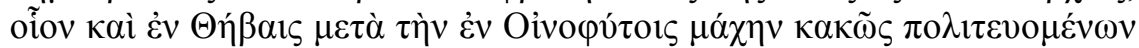
$\dot{\eta} \delta \eta \mu \kappa \kappa \alpha \tau i ́ \alpha \delta \varepsilon \varphi \theta \alpha \dot{\alpha} \rho \eta$.

Out of contempt result civil conflicts and even attacks, such as ... when in democracies the well-to-do become contemptful of the disorganisation and anarchy, like when in Thebes after the Battle of Oenophyta the democracy was destroyed because it was ill-governed. (Pol. 1302b)

"After" of course does not mean "soon after", and it is clear that Aristotle did see a period long enough for the aristocrat element at Thebes to grow discontented with the democracy. This is at odds with Diodorus' claim that the Thebans escaped Athenian domination entirely (11.83.1); Buck suggests that Diodorus' source Ephorus anachronistically applied the standards of his own period to assume that the defeat of "the Boeotians" in 457 excluded their hegemon, Thebes. ${ }^{248}$ It seems overwhelmingly unlikely that Thebes was independent for almost ten years while surrounded by Athenian-dominated Boeotian states. Aristotle seems to describe the overthrow as a form of $\sigma \tau \alpha \dot{\sigma} \sigma \varsigma$, , and not related to foreign politics, but it is clear that the Thebans actively overthrew the democratic constitution asserted by Athens and

\footnotetext{
${ }^{247}$ Bonner and Smith (1945), 15, suggest that the city of Thebes was also a centre for the revolution. They cite no evidence for this, because there is none.

${ }^{248}$ Buck (1979), 147.
} 
did not simply benefit from the general revolt. They may therefore have been the first polis in Boeotia to reestablish the oligarchic constitution.

The lack of direct reference to the Thebans in Thucydides' narrative is not sufficient to exclude them. The Thebans did claim responsibility for the victory in their speech at Plataea in 427 :

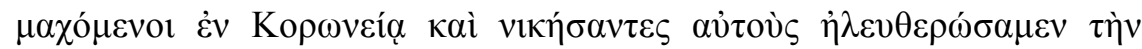

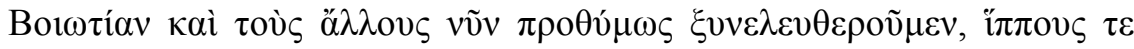

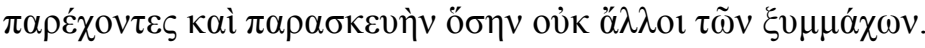

When we fought at Coronea and defeated them, we freed them then and we free now Boeotia and others eagerly, providing cavalry and gear beyond any other of the allies. (Thuc. 3.62.5)

Pagondas, in a speech to the collected Boeotian forces before the Battle of Delium, implies that Thebes was involved in defeating the Athenians, in rather less dubious rhetorical circumstances (Thuc. 4.92). Nor can it be clearly demonstrated that the Boeotians who rebelled were Orchomenians, or even led by Orchomenus. Thucydides does not anywhere refer to Athens' opponents as Orchomenians, but

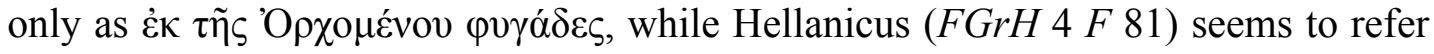

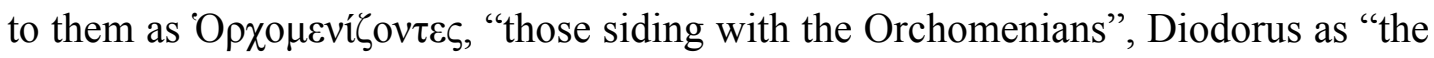

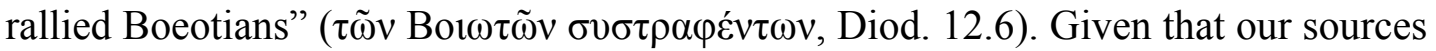

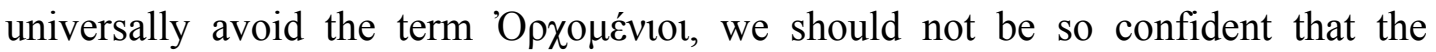
revolters were men of Orchomenus: ${ }^{249}$ the "Boeotian exiles" used Orchomenus as a base. At no point are the Boeotian forces in the revolt referred to simply as

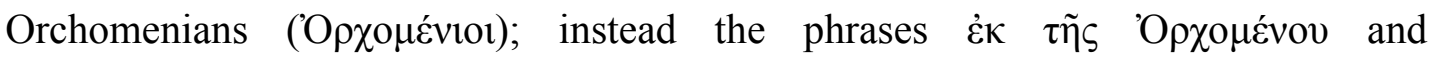

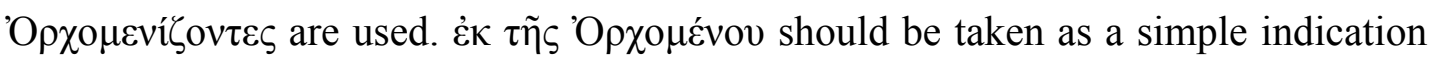
of their motion, not one of origin. ${ }^{250}$ Orchomenus is consistently masculine when

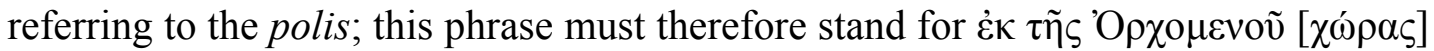
(vel sim.), "out of Orchomenian territory". ${ }^{251}$ Orchomenus was the base of the Boeotian revolt, but not its leader. Thebes, on the other hand, was clearly actively involved in the revolt; a synthesis of the accounts would suggest that it did in fact lead the Boeotians. ${ }^{252}$

\footnotetext{
${ }^{249}$ Buck (1979), 150.

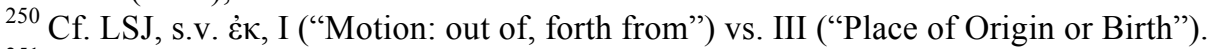

${ }^{251}$ Hansen (2004), 447, on the gender of the toponym.

${ }^{252}$ Buck (1979), 150, notes that Sparton (Plut. Ages. 19) is a markedly Theban name.
} 


\section{CONCLUSION}

Thebes was the primary participant in four military expeditions in the final years of the Archaic Period. All of these are referred to in historiographical sources as acts of "the Boeotians", and therefore presented as cooperative acts, but the details of these expeditions clarifies who was in fact involved: at Plataea (ca. 519), only Thebes; at Ceressus (late sixth century), Thebes and/or Thespiae; in Attica (506), mainly Thebes; at the Battle of Plataea (479), all of Boeotia, with the two exceptions are carefully noted. The aftermath of the failed expedition to Attica, however, saw Thebes claim to lead Thespiae, Tanagra and Coronea. By the time of the Battle of Plataea, the Theban oligarchs were concerned for the entire region.

Clearly, inter-state unity was most useful when there was an external threat: ${ }^{253}$ Buck argues that the pressure-point of Boeotian federal unity was the Thessalian attack which culminated in the Battle of Ceressus. ${ }^{254}$ There is overwhelmingly little evidence to suggest that this event resulted in a regional political structure. But the events between 520 and 480 clearly did encourage unification. The Battle of Coronea (447) seems a more likely breaking point, and one whose aftermath more clearly demonstrates the development of a Boeotian confederation. Once again Thebes seems to have led the Boeotians against an external threat, this time from Athens; Thebes' leadership, although doubted, seems clear. This leadership allowed it to establish a Confederate constitution which favoured it heavily, as discussed in the following chapter.

In the period between 506 and 447, therefore, we can see that Thebes was increasingly able to command military service from other Boeotian poleis. In the case of Plataea, at least, Thebes seems to have attacked a reticent state and confiscated some of its land for itself. The evidence of the Persian Wars suggests that Thebes led, and may perhaps have controlled Boeotia's relations with the Persians. These three aspects of the Theban relationship with Boeotia meet Finley's first, third and fifth criteria of imperialism.

\footnotetext{
${ }^{253}$ Schachter (1996), 24.

${ }^{254}$ Buck (1979), 107.
} 


\section{POLEIS AND CONFEDERATION: THEBES AND THE BOEOTIAN CONSTITUTIONS}

This chapter considers the position of Thebes within the fully constituted Boeotian Confederation, after 447 until 387, when the Confederation was forcibly dissolved according to the Spartan interpretation of the Peace of Antalcidas. I argue below that the Boeotian constitution gave the balance of decision-making power in the Confederation to Thebes. I will also argue that there are some indications that the power imbalance in the federal constitution was not a result of Theban manoeuvring after the foundation of Confederation, but rather that the constitution was one of the original mechanisms by which Thebes took power. In fact, the actions of the Confederation in practice suggest an even stronger position for Thebes than the constitutional dominance, as I will demonstrate.

It seems that in addition to the super-civic constitution of the Confederation, all the poleis of Boeotia conducted their local affairs through identical oligarchic constitutions, which I suggest were a Theban imposition. Thebes was, therefore, directly in control of some aspects of other Boeotian states' government through its plurality in the Confederation's councils and the college of Boeotarchs, in particular military affairs but also financial and judicial affairs. It held effective control of other aspects of local governments through the imposed oligarchic constitutions.

Finally, the circumstances of the Confederation's dissolution in 386 makes it clear that the Boeotian Confederation was not a free association (by that time) but a tool of Theban imperialism in Boeotia which gave Thebes control over the other poleis. Thus, Theban imperialism in Boeotia, I will argue, resulted in control over the rest of Boeotia from the Archidamian War.

This chapter relies extensively on the imperfect constitutional summary of the Hellenica Oxyrhynchia (16.2-4) and the testimony of the historiographers. Larsen argued that the Boeotian constitutions were an important example of Classical 
oligarchic political theory, ${ }^{255}$ but this significance is not reflected in ancient political writers: the Aristotelian school of constitutional scholars produced works on federal constitutions of Thessaly, Achaea and Lycia, at least, amongst their extensive

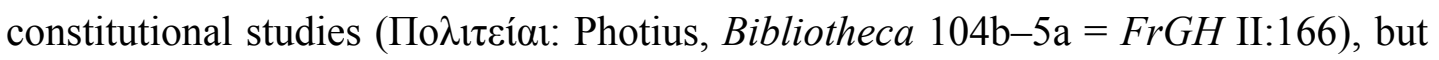

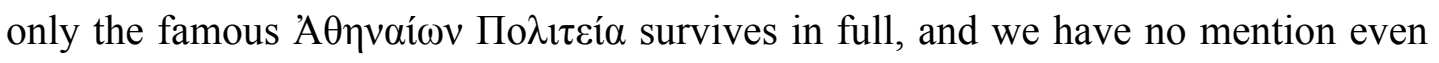
of a Federal Constitution of the Boeotians. ${ }^{256}$ There are no surviving inscriptions which relate to the Boeotian Confederation before its revival, in defiance of the Peace of Antalcidas, in $374 .{ }^{257}$ Much better documentation is available for the Hellenistic form of the League, but this was not a direct continuation of the Archaic and/or Classical League. ${ }^{258}$ Therefore we rely on ancient historiographical resources.

\section{THE BOEOTIAN CONFEDERATE CONSTITUTION}

Thebes is widely recognised as a prominent member of the Boeotian Confederation. It held the largest delegation in the representative Confederate government, providing two out of eleven divisions of the contributions to the government; its actual control, as I shall discuss, may have been even larger than the two parts assigned to it in the Hellenica Oxyrhynchia. The exact powers of the federal Boeotian government over the individual poleis are not clearly defined in our sources, but it is clear that the larger states and Thebes in particular were able to make decisions through the Constitution which were binding on the other Confederate participants. ${ }^{259}$ The Confederate constitution, I will argue, was designed to strengthen the hegemony of Thebes within Boeotia.

The constitution of the Boeotian Confederation after 447 is partially attested in a now well-known and extensively-studied fragment of the Hellenica Oxyrhynchia (P.Oxy. 842). ${ }^{260}$ The information is conveyed in a tangent to the narrative of the

\footnotetext{
${ }^{255}$ Larsen (1955).

${ }^{256}$ See Larsen (1945), 74 n. 55, and (1968), xiii, more generally: the lack of a written analysis of the Boeotian constitution does not mean one was not or could not have been written.

${ }^{257}$ Rhodes and Lewis (1997), 122.

${ }^{258}$ See esp. Roesch (1965), 46-71.

${ }^{259}$ Demand (1982), 37.

260 The relevant chapter number has been revised with the discovery of new fragments and the reanalysis of the text of the Hell. Oxy., though not all scholars have followed the updates (see Behrwald [2005], 26): Grenfell and Hunt $11=$ Bartoletti $16=$ Chambers 19. Here I use the numbering of Bartoletti's first, better Teubner edition.
} 
developments of 395, at the start of what would become the Corinthian War. The unknown author was perhaps a contemporary of the constitution he discussed, although the word $\tau$ ó $\varepsilon \varepsilon$ at the start of the tangent is widely interpreted as suggesting that the Hellenica Oxyrhynchia itself was written after 387 and the dissolution of the Boeotian Confederation in the form described, with the author $(\mathrm{P})$ reminding his audience that the constitutions described differed from the present-day arrangement of Boeotia. ${ }^{261}$ It is a moot point whether $\tau$ ó $\tau \varepsilon$ should be taken in a limited sense, "at that particular time", referring solely to 395 (in which case P obliquely acknowledged the possibility of constitutional developments between 447 and 395); or more generally, "in those days", in which case we should take the constitution described as definitive for the full period. Neither case can be clearly proven. $\mathrm{P}$ describes, in a fairly terse sketch, both the local constitutions ( $\tau \dot{\alpha} \imath^{\prime} \delta 1 \alpha$ ) of the

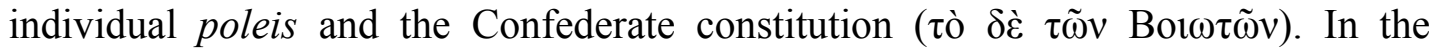
interests of clarity I have quoted and translated the digression in full:

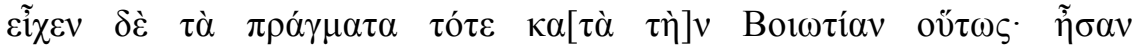

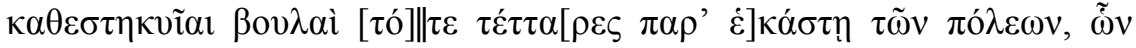

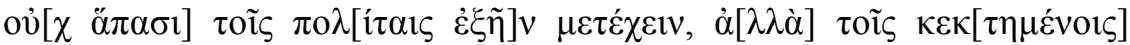

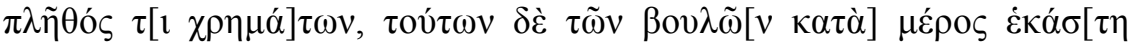

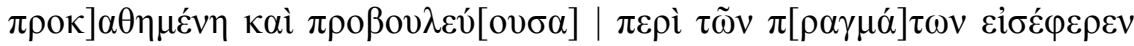

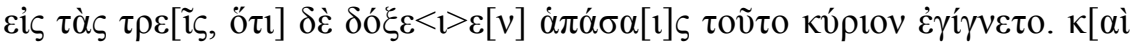

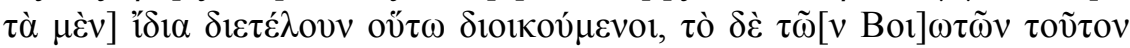

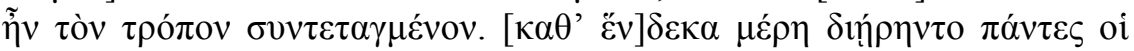

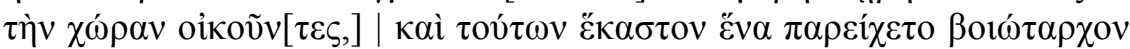

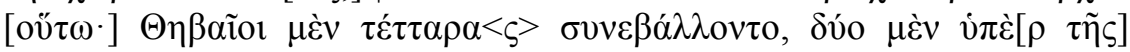

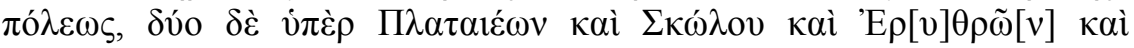

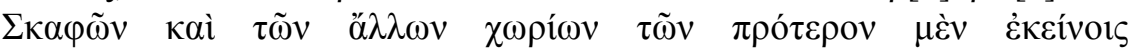

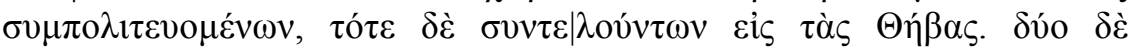

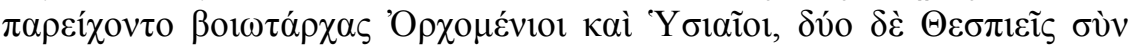

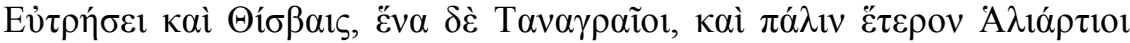

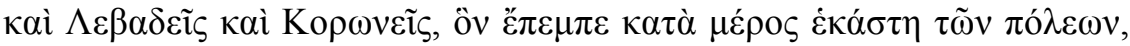

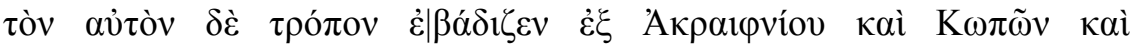

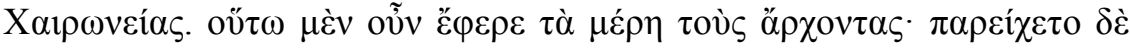

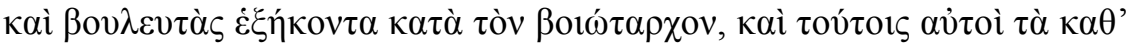

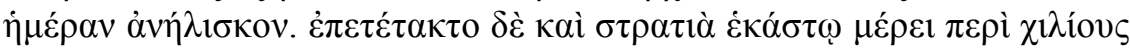

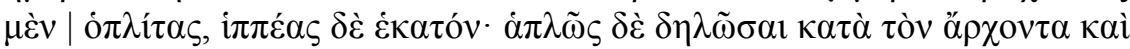

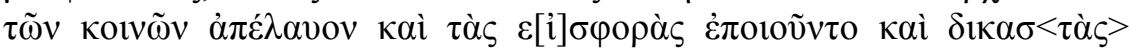

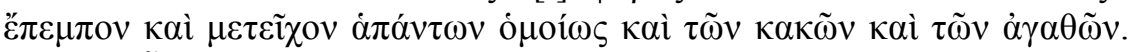

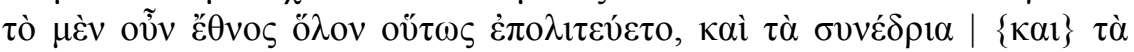

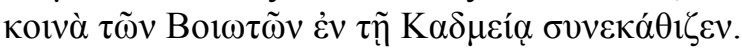

\footnotetext{
${ }^{261}$ Cartledge (2000), 400, argues for a date after the reformation of the Confederation in 378. I will follow standard practice in referring to the author as "P" (Papyrus), though Cratippus is now favoured by many as the author: on the disputed identification of the author (Ephorus, Theopompus, Androtion or Cratippus?), see Harding (1987), Cartledge (2000), 398.
} 
At that time, affairs within Boeotia were thus: at that time, four councils had been established in each of the cities [poleis], which not all of the citizens could take part in, but only those with some degree of wealth. Each of those councils sitting in turn and prejudging matters took them to the [other] three [councils], and what they all decided became lawful.

Their local affairs they continued to arrange thus, but the affair of the Boeotians had been arranged in this way: all those who lived in the region were divided into eleven parts $[\mu \varepsilon \dot{\varepsilon} p \eta]$, and each of these parts provided one Boeotarch thus. The Thebans contributed four, two on behalf of their city, and two on behalf of the Plataeans, and Scolus, Erythrae and Scaphae and the other areas which had previously been a political unit with them $[\sigma \nu \mu \pi \circ \lambda ı \tau \varepsilon v o \mu \varepsilon \varepsilon v \omega v]$, but were at that time considered part of Thebes. And the Orchomenians and Hysians provided two Boeotarchs, the Thespians with Eutresis and Thisbae two, the Tanagrans one, and the Haliartans, Lebadeans and Coroneans another, whom each of the cities sent in turn, and by the same way he [a Boeotarch] came from Acraephnium, Copae and Chaeroneia.

So thus the parts sent their magistrates, and they provided as well sixty councillors per Boeotarch, and they financed them every day. The army, too, was assembled from each part at around a thousand hoplites and one hundred cavalry each; simply put, they drew upon the common resources and made contributions and sent judges according to their magistracies, and took part in everything equally, the good and the bad. So the entire race [ $\ddot{\varepsilon} \theta v o \zeta]$ took part in the government, and the common congresses

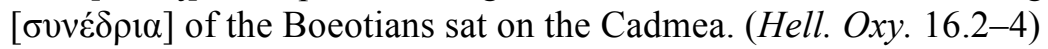

The Hellenica Oxyrhynchia has been lauded for illuminating the otherwise poorlyattested political situation in Boeotia in the late fifth and early fourth centuries. ${ }^{262}$ However, there is good reason to believe that the description here is incomplete. The Hellenica Oxyrhynchia states that there are four councils in each of the Boeotian poleis (16.2), but at the confederate level mentions only councillors ( $\beta$ ov $\lambda \varepsilon v \tau \alpha i ́$, 16.4), sixty to each Boeotarch. Thucydides, however, has the Boeotarchs consult "the four councils of the Boeotians" on the matter of an alliance with Corinth and Argos in 421:

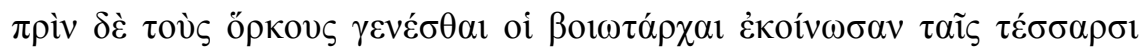

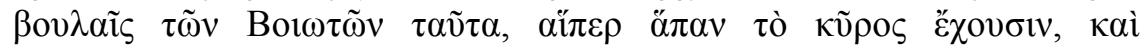

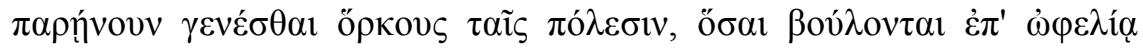

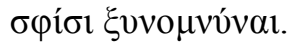

Before oaths were taken, the Boeotarchs communicated these proposals to the four councils of the Boeotians, which were in fact fully in charge, and advised them to take oaths with the poleis which were willing to swear to a defensive alliance between each other. (Thuc. 5.38)

${ }^{262}$ Larsen (1968), 26. 
On the basis of this evidence it seems that $\mathrm{P}$ neglected to mention both the four councils at the federal level and their importance within the Confederate government. It is possible that either Thucydides or the Hellenica Oxyrhynchia has misrepresented the situation due to a confusion between the local and confederate arrangements, but neither source contradicts the details presented in the other description; ${ }^{263}$ they are both simply partial discussions. We should therefore take caution with the assumption that the information in the Hellenica Oxyrhynchia is a full discussion. In particular, we should not assume that P largely neglected the financial or judicial aspects of the Confederation because they were a small part of its functioning; ${ }^{264}$ his discussion in the section is focused on the archons and deliberative bodies, as those most relevant to his discussion of Boeotian factionalism in $395 .{ }^{265}$ His discussion here is therefore incomplete.

According to the Hellenica Oxyrhynchia, representation in the Confederate

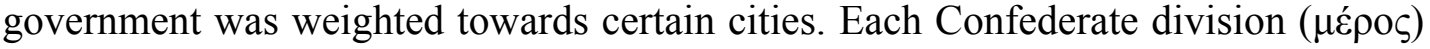
provided one Boeotarch, sixty councillors, one thousand hoplite soldiers, one hundred cavalry soldiers, and an equal portion of jurors ( $\delta 1 \kappa \alpha \sigma \tau \alpha i)$ and an equal

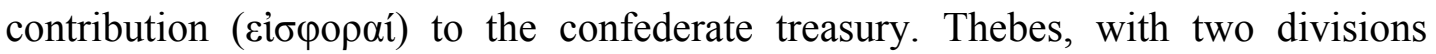
( $\mu \varepsilon ́ p \eta)$, contributed approximately 2200 hoplites and cavalry to the confederate army, but it also had six times the number of votes on the sovereign councils than those of Haliartus, Lebadea, Coronea, Acraephnium, Copae and Chaeronea, which shared two $\mu \varepsilon \dot{\varepsilon} \eta$ between six poleis. The nature of the shared divisions is not entirely clear: P states that the poleis in the two shared $\mu \varepsilon \dot{\rho} \eta \eta$ sent their Boeotarchs in turns, but it is possible that the other contributions (councillors, jurors, military and financial levies) were proportioned rather than provided in turns. ${ }^{266}$ The number sixty given for Confederate councillors would suit a proportional representation, as it is easily divisible as would be necessary: divided by the three cooperating poleis,

\footnotetext{
${ }^{263}$ McKechnie and Kern (1988), 157.

${ }^{264}$ Pace Larsen (1968), 36.

${ }^{265}$ For example, light infantry are not mentioned at all, although "over ten thousand" were in the Boeotian line at Delium (Thuc. 4.93). They almost certainly were second-class citizens, and therefore do not matter to P: Bonner (1910), 407.

266 At Delium, Thucydides mentions (4.93) both Haliartans and Coroneans from the tenth $\mu \varepsilon \varepsilon \rho \varsigma$ holding the centre of the Boeotian battle line, but only Copaeans from the eleventh. Bonner (1910), 410 , suggests that military contributions were not subject to the same regulations as the political contributions.
} 
twenty councillors each were provided, ${ }^{267}$ giving five councillors from each polis to each of the four confederate councils. ${ }^{268}$ It is clear, however, that the Theban polis was substantially represented at all times in the sovereign councils. No other Boeotian polis is ascribed two unshared $\mu$ ćpך in P's description. ${ }^{269}$ This alone would give Thebes a substantial advantage in confederate decision-making.

The numbers were further stacked in Thebes' favour. Thebes controlled a further two $\mu \varepsilon ́ \rho \eta$ "on behalf of" (i் $\dot{\varepsilon} \rho)$ Plataea et al. It is not clear what this might mean. Perhaps Thebes took on the administrative matters of electing Boeotarchs from the Plataean region when the Plataean government could no longer do so, ${ }^{270}$ given the destruction of the city at the end of the Theban and Spartan siege, but by 427 the majority of the Plataean citizen population had fled, while those who remained were killed and enslaved when Spartan and Theban forces took the city (Thuc. 2.6.4, 3.68.3). A few Plataeans, loyal to the Spartans, and Megarians were briefly resettled in the ruins (Thuc. 3.68.3). The size of this new settlement was surely not comparable to Thebes or the combined populations of Thespiae, Eutresis and Thisbe, and yet it continued to hold two $\mu \varepsilon \dot{p} \eta$ in the Confederate government. It is certainly dubious that this much-reduced Plataea, even with the smaller cities, could furnish 2,000 hoplites and 200 cavalry. ${ }^{271}$

It is generally assumed that Thebes' involvement in Plataea's representation in the Confederation dated to the fall of Plataea in $427 .{ }^{272}$ However, there is no evidence that Plataea was involved in the Confederation prior to 431: in fact, although the Theban attack on Plataea in 431 was led by two Boeotarchs, neither the Theban invitation to pro-Confederation Plataeans on their incursion in 431, nor the Theban

\footnotetext{
${ }^{267}$ Salmon (1985), 302.

${ }^{268}$ Glotz (1908), 277-78. Cartledge (2000), 405, argues for careful calculation in the development of the constitution, without explicitly making the point suggested here. See McKechnie and Kern (1988), 154-57, on the theoretical background to the constitution.

269 This may be a matter of presentation rather than reality; a number of Boeotian poleis which may have depended on Thebes (Mycalessus, Aulis...) are completely absent from the description.

270 Thebes had been invited to Plataea, according to Thebans (Thuc. 3.65.2); see Amit (1973), for discussion of the Plataean aristocracy's concerns.

271 Plataea fought $\pi \alpha v \delta \eta \mu \varepsilon i$ at Marathon (Hdt. 6.108.1), which Nepos and Justin placed at 1,000 soldiers (Milt. 5.1; 2.9.9), and suplied 600 hoplites to the Battle of Plataea (Hdt. 9.28.6). 400 Plataeans resisted the Theban incursion (Thuc. 2.78.3). Amit (1973), 93-94, estimated 5,000 (total population), Hansen (1997, 27-28), 2,000 (citizens) at the start of the Peloponnesian War.

${ }^{272}$ Buck (1979), 155.
} 
justification during the trial of the Plataeans (Thuc. 3.53-68) of their actions, implies that the Plataeans had previously been participants in the Confederation:

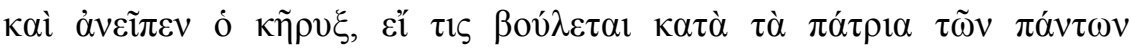

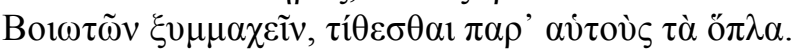

The herald announced that if anyone wanted to join the symmachy, according to the ancient traditions of all the Boeotians, they should take up arms. (Thuc. 2.2)

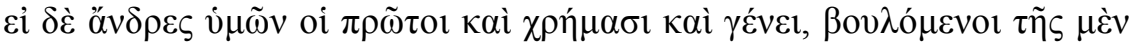

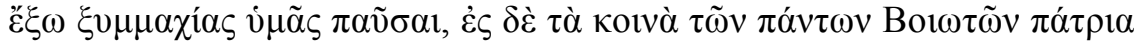

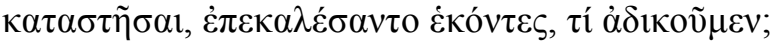

If the first men in your city both in wealth and ancestry, wanting to stop your alliances $\left(\xi v \mu \mu \alpha \chi i \alpha_{\zeta}\right)$ with outsiders and to give you over to the ancestral commonwealth of all Boeotians, voluntarily called on us, what wrong did we do? (Thuc. 3.65)

Both statements appeal to the ancestral Boeotian ways. As already discussed in chapter one, this was a significant rhetorical point in the conflict between Thebes and Plataea. However, in the first statement, the herald's words only invite Plataean citizens to fight with other Boeotians. Buck asserts that the meaning of these two passages was an invitation for Plataea to return to the Confederation. ${ }^{273}$ It is unusual for $\kappa \alpha \theta i ́ \sigma \tau \eta \mu$ to imply "return" or "restore" without $\pi \alpha ́ \lambda \mathrm{s}$; such usage only occurs in poetry. ${ }^{274}$ Barring the assumption that Plataea was encouraged to join the Boeotian Confederation in 519, which is central to much scholarly interpretation of the 431 dispute, there is little evidence to suggest that the Plataeans had participated in the Boeotian Confederation in the sixteen years between 447 and 431, much less joined and left the Confederation in that short period. ${ }^{275}$

There is thus no reason to believe that the Plataean divisions of the Confederation existed before the fall of Plataea in 427. It seems equally possible that the Plataean divisions were established later than the other federal divisions, and were always intended to be subject to Theban control. ${ }^{276}$

The answer to the question of Plataea's contributions to the Confederation after the Theban occupation, and a hint at Thebes' involvement in the Plataean divisions, may

\footnotetext{
${ }^{273}$ Buck (1979), 161.

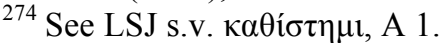

275 Pace Amit (1973), 87; Hansen (2004), 450. Amit does suggest (1973), 70, that Plataean resistance to the Confederation would have rested on the democratic nature of their government.

${ }^{276}$ Bruce (1967), 105; (1968), 190 (esp. n. 5 on the history of this analysis).
} 
be found in the description of other subordinate towns in the region. P states, as cited above, that the Plataeans shared their two divisions with the people of Scolus, Erythrae and Scaphae. Based on the Hellenica Oxyrhynchia's evidence alone, many scholars proposed that Plataea led a small sympolity, a genuine federation of towns in southern Boeotia in the mid-fifth century. ${ }^{277}$ However, Scolus and Copae were both known to adhere rather more closely to Thebes than Plataea before the Battle of Coronea. ${ }^{278}$ We must therefore construct a Plataean federation which drew in smaller cities from the Theban sphere of influence, with no evidence for what would doubtless have been a substantial point of tension between Plataea and Thebes; we would expect it to be mentioned as one of the Plataean transgressions in Thucydides' Plataean Debate. Moreover, the Hellenica Oxyrhynchia states that these smaller, unwalled cities were synoecised with Thebes at the beginning of the Peloponnesian War:

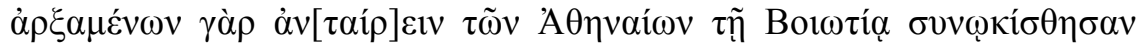

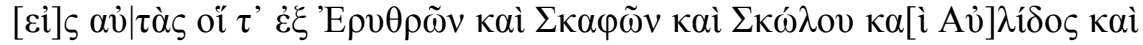

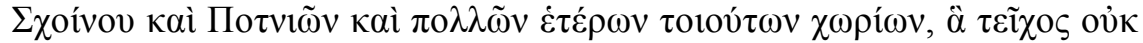

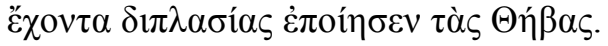

When the Athenians began to move against Boeotia the residents of Erythrae, Scaphae, Scolus, Aulis, Schoenus, Potnia and many other such towns without walls were synoecised to [Thebes], and doubled the size of Thebes. (17.3)

As Bruce argues, this must have been in $431 .^{279}$ The threat from Athens does not make sense as a motivation if these cities were dependent on Plataea, which was supported by the Athenians and not besieged by Spartan forces until 429 (Thuc. 2.71). It is perhaps more logical to interpret the phrase $\tau \tilde{\omega} v \alpha \tilde{\alpha} \lambda \lambda \omega v \chi \omega \rho i ́ \omega v \tau \tilde{\omega} v$

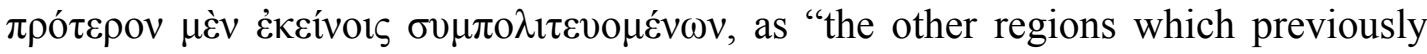

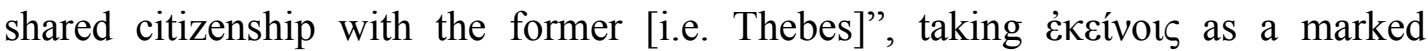

\footnotetext{
${ }^{277}$ Hansen (2004), 250. Bonner (1910), 409, suggests that this was a league under Athenian protection. Larsen (1968), 34, implies that the $\mu \varepsilon ́$ pos of Plataea, Scolus, Erythrae and Scaphae was designed to create a buffer between Thebes and Attica. There is no particular geographical significance to the divisons; Plataea could not have provided any more of a buffer than it had in the past. Amit (1973), 87, argues that the freedom guaranteened to Plataea by the Greek states at the end of the Persian Wars (Plut. Arist. 21; Thuc. 2.71.2) meant that they no longer feared Thebes; Plataea's fate makes it clear that their security was fragile, as Debnar $(1996,103)$ argues.

${ }^{278}$ Larsen (1968), 29. Bruce (1968), 192, argues that the geographical references to Boeotia in the evidence used by Larsen and Salmon (1958) are not substantive enough to argue for Thebes' control of the small cities, but the position of Scholus in 479 at least is unquestionable: Hdt. 9.15.2.

${ }^{279}$ Bruce (1968), 191.
} 
demonstrative pronoun, "the former"; the contrast drawn then is not one of hegemons, but of the relationship with the hegemon Thebes: they had previously shared Theban citizenship (i.e. after the synoecism of 431), but were now only dependent on Thebes. ${ }^{280}$ The change in citizenship increased the value of Thebes' representation within the Confederation, which had perhaps been reduced by the synoecism at the start of the Peloponnesian War. ${ }^{281}$

Even the new settlement at Plataea was in existence only briefly; Thucydides mentions in the same sentence that explains the resettlement that Plataea was razed a year later (Thuc. 3.68.3). Thereafter Plataea became the property of Thebes, and the land was rented out to Theban farmers. Bruce has suggested that the income from these leaseholdings may have given these Theban farmers full franchise (cf. Hell. Oxy. 16.2). ${ }^{282}$ It is far from certain that income rather than property-owning was sufficient to meet the qualifications vaguely described in the Hellenica Oxyrhynchia, but it is clear that the conquest of Plataea entailed substantial profit both for the Theban state and for individual Thebans.

The particular success of the Plataean conquest was Thebes' transformation of the eviction of the population of its southern neighbour into a constitutional acquisition within the Boeotian Confederation. The people of the Platais, having succumbed to the siege by 427 , fled to Attica, where they were offered a form of Athenian citizenship. $^{283}$ It seems that the Athenians did not believe that Plataean territory would be reconquered again any time soon. This, after all, was not the typical result of wars between Greek states: usually, affairs returned to the status quo ante, with the losing state making only a few concessions for peace to the victor (the final result of the Peloponnesian War was notably such, although only the insistence of

\footnotetext{
${ }^{280}$ See Bakhuizen (1994) on the exact meaning of $\sigma v v \tau \varepsilon \dot{\lambda} \varepsilon 1 \alpha$, "dependence on" or "obligation to" a greater state.

${ }^{281}$ Cartledge (2000), 406, argues that the synoecism doubled the territory of Thebes' $\mu \varepsilon \dot{\rho} \eta$; this is a

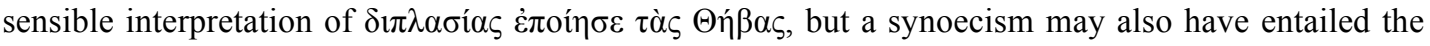
expansion of the franchise.

${ }^{282}$ Bruce (1968), 196.

${ }^{283}$ In Thucydides $(3.55 .3,3.63 .2)$ it seems that Plataean citizenship at Athens dated to the original alliance; later orators (Isoc. Panath. 94; [Dem.] 54.104) present it as granted in 427. Amit gives a clear overview of the arguments $(1973,74-76)$, concluding concluded that the disasters of the

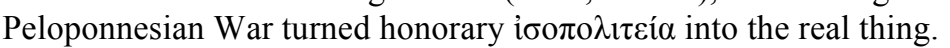


Sparta spared Athens from much harsher penalties). The Plataean flight was a marker of the unusual circumstances of the Peloponnesian War.

The presumption that the burdens of extra representation would make the acquisition of Plataean territory undesirable relies on the assumption that these outweighed the benefits in terms of voting rights. ${ }^{284}$ It is important to note here that there is no indication that the $\mu \varepsilon \dot{\rho} \eta$ were anything more than a means of apportioning

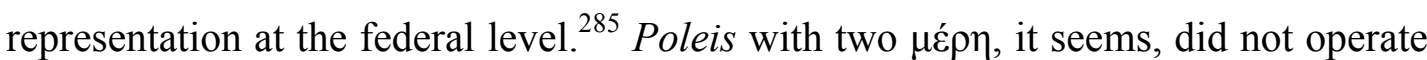
these divisions separately: there is no suggestion in $\mathrm{P}$ that the greater poleis were split geographically or politically for federal purposes, nor anything to suggest a natural bipartite division in Boeotian states (Boeotia, like many Aeolian-speaking regions, did not reflect the $\varphi v \lambda \eta$-divisions of Ionian and Dorian regions at this time). ${ }^{286}$ Thebes, as a whole, provided double the number of federal officials and contributed double the number of soldiers to the federal forces as its neighbour Thespiae. This renders P's assertion that Thebes operated the former Plataean $\mu \varepsilon \varepsilon^{\prime} \eta$ more complex: if the $\mu \varepsilon ́ \rho \eta$ were not tied to a particular geographical region, nor to a specific body of citizens (the citizens of Plataea having in any case evacuated to Attica), then Thebes had simply doubled again its representation within the League. This did not entail the maintenance of the existing proportionality of Boeotian government, as the destruction of Plataea and the removal of Plataean citizens to Athens should have resulted in the abolition of the Plataean $\mu \varepsilon \dot{\varepsilon} \rho$, which no longer offered the same resources for the Boeotian forces. The Theban appropriation of two extra $\mu \varepsilon ́ \rho \eta$ was a simple consolidation of power.

Theban gerrymandering has more readily been recognised in the representation of Orchomenus. The dynamics of sharing multiple divisions between multiple centres are even less clear in P's description than the description of the shared single divisions. Larson has proposed that on establishing the Boeotian Confederation, Orchomenus controlled three federal $\mu \varepsilon ́ p \eta$, including the two smaller towns

\footnotetext{
${ }^{284}$ Pace Larson (1945), 33.

${ }^{285}$ Bruce (1967), 104

${ }^{286}$ Salmon (1985), 302. The presumption (cf. Bonner [1910], 409; Larsen [1945], 33; Bruce [1968], 195; Cartledge [2000], 404) that the federal divisions were genuinely proportional (i.e. roughly equal in size) is hard to prove or disprove without good figures for the number of citizens in Boeotia at the time: see Buck (1979), 160, for estimates.
} 
Chaeronea and Hysiae/Hyettus. ${ }^{287}$ Chaeronea was later detached by the Thebans and turned into a $\mu$ śpo beyond the control of Orchomenus, thus rendering Orchomenus much weaker in the Confederation. The evidence for this is rather indirect: Thucydides says that Chaeronea depended on Orchomenus in 424 (4.76.3), while in the Hellenica Oxyrhynchia Chaeronea was part of one of the two divided $\mu$ śpๆ. Little noted is that Thucydides' notice of Chaeronea as dependent says Xaipoveíav

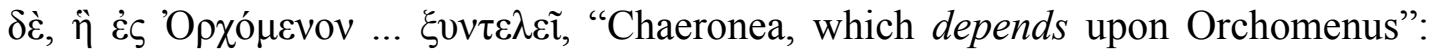
note the present tense of $\xi v v \tau \varepsilon \lambda \varepsilon \tilde{i}$. Larsen's proposals for the date of Thebes' interference (which per se acknowledge Thebes' power in the Confederation) associate it with the attack on Thespiae in $424 .{ }^{288}$ This cannot be the case unless Thucydides' notice itself was written ca. 424 and escaped later revision. Moreover the detachment must then have involved the sudden promotion of Chaeronea's partners (Acraephnium and Copae) from no representation at all to one third of a full share in the $\mu \varepsilon^{\prime} \rho \varsigma_{\zeta}$ which $\mathrm{P}$ describes. ${ }^{289}$ The idea is tenuous on a number of grounds, not least the presumption that the reduction of Chaeronea was the most aggressive move which Thebes could make against Orchomenus. ${ }^{290}$ Chaeronea clearly would not have been able to assert its own independence even if was explicitly granted its own $\mu \varepsilon ́ p o \varsigma$, or else it would not have been necessary to reduce it to only one third of a division. It seems more likely that Chaeronea had always been afforded a partial representation in the Confederation.

It is equally agreed that Orchomenus retained two $\mu \varepsilon ́ p \eta$ until 395. However, to have control of two divisions (equal to the representation of Thebes) Orchomenus must have dominated the second grouping of poleis given in the Hellenica Oxyrhynchia (after Thebes et al.), and here too there is difficulty. The papyrus names Hysiae, a small town south of Thebes and a thoroughly unlikely bedmate for Orchomenus, in the same grouping. ${ }^{291}$ The reading has consistently been corrected to refer to Hyettus, ${ }^{292}$ but the corruption from 'Y

\footnotetext{
${ }^{287}$ Larsen (1960);

${ }^{288}$ Larsen (1960), 16.

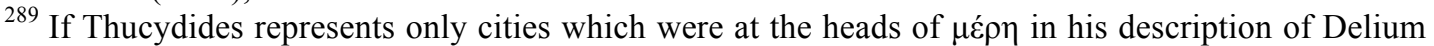
(4.93), then the inclusion of Copae is problematic.

${ }^{290}$ Larsen (1960), 16.

${ }^{291}$ The issues are excellently summarised by González (2008), 24-28.

${ }^{292}$ Beginning with Wilamowitz's correction, taken up by Grenfell and Hunt: González (2008), 25.
} 
has not made any other glaring errors here. Hysiae should stand uncorrected. It may still be possible that Orchomenus and Hysiae formed a non-contiguous group within the confederation, as did Acraephnium, Copae and Chaeronea. However, the presumption that P's conjunction of the two towns is meaningful does not bear up under scrutiny. Firstly, the conjunction kaì in the two shared divisions apparently denoted equal representation. No two groupings, however, are described with exactly the same formulae; it cannot therefore be presumed that $\kappa \alpha$ means an equal relationship in the Boeotian constitution. ${ }^{293}$ There is, therefore, no explicit information in the description regarding the relationship. Secondly, the list of groupings follows no particular order, so it is not impossible that $\mathrm{P}$ described Orchomenus and Hysiae together without intending to associate the two towns.

On the whole it seems quite possible that the Boeotian constitution gave just one representative division to Orchomenus, with another given to the small town of Hysiae near Thebes, and one third of a division to Orchomenus' dependent Chaeronea.

Thebes therefore provided or controlled 240 out of the 660 councillors for the Confederate Council. Moreover, the councils met and the treasury was kept on the Theban acropolis, a fact which must have been advantageous to Thebes. ${ }^{294}$ Not only were Theban councillors more conveniently able to participate in council, but opponents of Thebes had to come into the heart of Theban territory in order to participate at all. If councillors were required to be resident at Thebes, the volatility of Boeotian politics made them effectively hostages. Larsen argues that the central location of Thebes made it the most convenient administrative capital. ${ }^{295}$ However, a central and neutral location in Boeotia was not impossible, for such was Onchestus when it became the federal capital in 338 . The determination of Thebes as the federal capital was surely more to the advantage of Thebes than for the convenience of the other federal poleis.

\footnotetext{
${ }^{293}$ González (2008), 28.

${ }^{294}$ Demand (1982), 37; Cartledge (2000), 405-6.

${ }^{295}$ Larsen (1968), 35.
} 
A handful of supporting votes from each of the other districts would have given Thebes a majority at the council. ${ }^{296}$ Prevalent factionalism in Boeotia, even with the aggressive oligarchic constitutions, probably entailed a pro-Theban party in each polis; but this was certainly also a problem in Thebes too. With no information about the selection of councillors for each polis, however, we cannot assume that every councillor from Thebes was a supporter of the leading party. However, while the council seems to have been the sovereign body, much of the actual government of the Confederation fell to the college of eleven Boeotarchs. Larsen suggests that this was a practical response to the logistical difficulties of holding the council meetings at Thebes. ${ }^{297}$ This cannot, however, have been an unexpected or accidental aspect of the Confederate council. The operative powers of the Boeotarchs were carefully designed to place the majority of power with a very small group of people. Thebes' control of four divisions would have provided a stronger presence within the college of eleven Boeotarchs.

\section{THE CONFEDERATION IN PRACTICE}

It seems that Boeotarchs did not expect their guidance to be rejected by the Boeotian federal councils. ${ }^{298}$ Thucydides records a proposed alliance between Boeotia, Corinth, Megara and Argos which failed when the Boeotian councils rejected the Boeotarch's advice. This is the only account of the internal decision-making process of the Boeotian Confederation in practice; Thucydides makes it clear that the failure was exceptional:

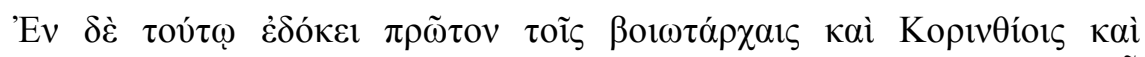

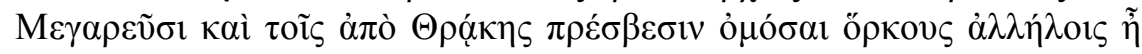

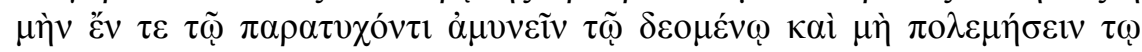

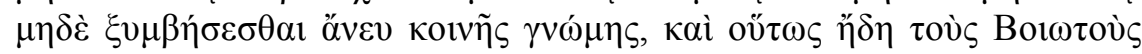

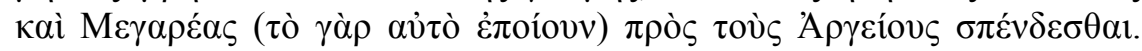

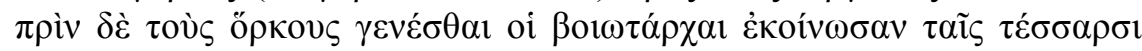

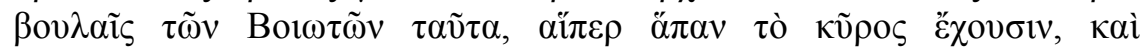

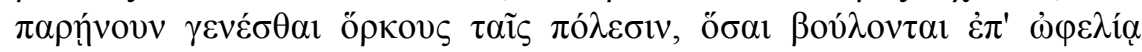

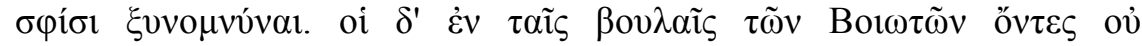

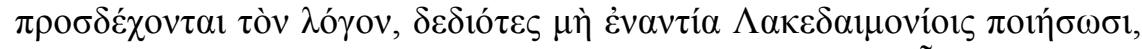

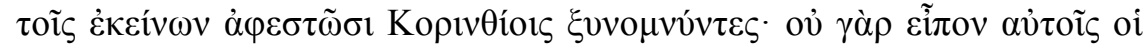

\footnotetext{
${ }^{296}$ Larsen (1968), 38.

${ }^{297}$ Larsen (1968), 35.

${ }^{298}$ Larsen (1968), 35.
} 


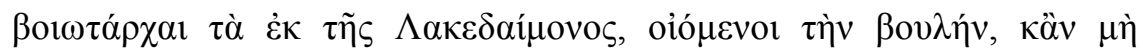

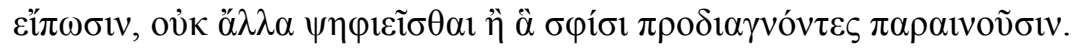

In the meanwhile, the Boeotarchs, Corinthians, Megarians and the ambassadors from Thrace decided firstly to swear oaths with each other to give help as required and to not go to war or to peace without common consent, and thus the Boeotians and the Megarians (who were doing the same thing) would make treaty with the Argives; but before the oaths were done the Boeotarchs publicised these things to the four councils of the Boeotians, which are entirely sovereign, and advised them to make the oaths with the poleis which there willing to enter into defensive alliance with them. But the Boeotians in the councils did not approve the proposal, afraid that they might displease the Lacedaemonians by making treaty with the Corinthians who had deserted them. For the Boeotarchs had not explained to them what had happened at Lacedaemon ... assuming that even if they did not say, the council would not vote for anything other than what they had decided and advised. (5.38)

It is possible that the rejection represents a party conflict within Boeotia, but this is speculative. ${ }^{299}$ The failure did not come because the Boeotian council took exception to the Boeotarchs arranging foreign policy, but only because the Boeotarchs did not communicate an important piece of information. The reason which Thucydides gives, that they had not thought it necessary to explain the proposal, indicates that in the normal state of affairs the council generally ratified proposals from the Boeotarchs without question. Practical power in the Confederation lay with the Boeotarchs, a small college of eleven men, at least four of whom were Thebans. The selection process for the Boeotarchs is unclear, but it seems likely that they were more easily controlled by the Theban faction in power than the wider councils.

In practice, a single Boeotarch often seems to have been plenipotentiary: ${ }^{300}$ the attack on Plataea in 431 was led by two Boeotarchs, not the full college (Thuc. 2.2.1). In most cases the active Boeotarchs, where identifiable, were Theban. The Boeotarchs at Plataea, Pythangelus and Diemporus, are both known to be Thebans, leading an apparently Theban force, as was Scirphondas (Thuc. 7.30). Pagondas, the Theban Boeotarch at the Battle of Delium (here referred to as one of two Theban Boeotarchs), was hegemon at the time and therefore made the final decision to conduct the battle. The Boeotarchs who prevented Agesilaus from sacrificing at Aulis are not identified in Xenophon (Hell. 3.4.4), but Plutarch notes that Agesilaus

\footnotetext{
${ }^{299}$ Buck (1994), 20-21.

${ }^{300}$ Larsen (1968), 35.
} 
was "enraged at the Thebans" ( intervention of the Boeotian officials. Only the Boeotarchs involved in the diplomatic mishaps at 5.37-38 are not named or limited; this may have been the full college. There is no individual Boeotarch who may be identified as non-Theban before the Peace of Antalcidas. Given the powers of the Boeotarchs, this makes evident the degree of agency which the Thebans possessed in the Confederation.

In 423, the Thebans tore down the city walls of their neighbour Thespiae for its Atticism. Thucydides' description of the act provides three illuminating details on the relationship between Thebes and Thesipae:

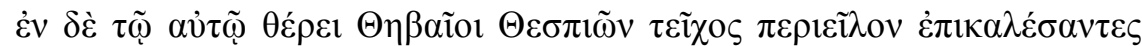

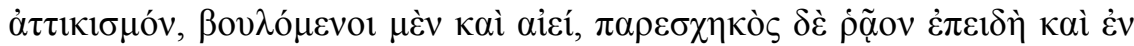

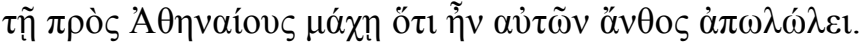

In the same summer, the Thebans removed the wall from Thespiae, having accused them of Atticism, which they had been wanting to do forever, but it was then an easy matter, as the flower of their youth had died in the battle against the Athenians. (4.133.1)

Firstly, the aorist aspect of $\dot{\varepsilon} \pi \iota \alpha \lambda \dot{\varepsilon} \sigma \alpha \nu \tau \varepsilon \varsigma$ implies that Atticism was not simply the pretext under which the Thebans acted at Thespiae, but an earlier complaint, perhaps even a formal charge made in the context of the Boeotian League or the Spartan alliance. $^{301}$ Thucydides certainly implies that the charge is false by offering no substantiation of the Theban accusation nor of a swing in Thespian sentiments; he in fact highlights the recent Thespian losses in the anti-Athenian cause (at the Battle of Delium). Larsen suggests that the casualties may have reduced the strength of the oligarchs in Thespiae, but Thucydides mentions the losses only in terms of the advantage this gave Thebes. ${ }^{302}$ Atticism was eventually to come at Thespiae (in 414: Thuc. 6.95.2), in the form of an attempted democratic revolution which Thebes helped to suppress, but there is no evidence of such, as yet, in $423 .^{303}$

The destruction of the walls is unambiguously depicted as a direct act of the Thebans against the Thespians as a whole. ${ }^{304}$ There is no implication of a complicit party

\footnotetext{
${ }^{301}$ Larsen (1968), 37; Buck (1994), 18-19; there is no substance behind Larsen's suggestion that the Thebans "undoubtedly had secured in advance a federal judgement against the city".

${ }^{302}$ Larsen (1968), 38.

${ }^{303}$ Pace Buck (1994), 18, who argues that Confederate security was at stake.

${ }^{304}$ Larsen (1968), 37.
} 
within Thespiae, as there is when Thebes helped to suppress the democratic revolution in 414. In fact, the violence of the act is clearly indicated by Thucydides' note that it was "even more easily achieved" when Thespiae's military was already depleted by the heavy losses at Delium, but "even more" suggests that although Thebes (or perhaps Thucydides himself) expected resistance of some kind, it was not a concern sufficient to discourage Thebes' attempt to dismantle the walls.

The suggestion that Thebes was accomplishing something "they had always wanted" is clearly a hyperbole on Thucydides' part (although one which acknowledges the antagonistic tendencies of neighbouring states). In particular, destruction of the walls was not a simple act of hostility: the destruction of the walls of Athens in 404 was not only a physical marker of Athenian defeat, but intentionally crippled Athenian defences and Athens' ability to assert its autonomy. Thespiae was then Thebes' closest neighbour, and without its walls could no longer be a potential safe haven for Atticist enemies, or anyone who wished to move against Thebes. ${ }^{305}$ The destruction of the walls was also an attack on the status of Thespiae: Greek discourse (if not actual Greek practice) placed a heavy emphasis on walls as a key feature of the autonomous polis. ${ }^{306}$ There was potentially as much symbolic as practical value in removing Thespiae's walls.

It must be concluded then that Thebes took an aggressive, and apparently unilateral, step to further disable the defences of its ally and closest neighbour without formally interfering with Thespiae's autonomy or effecting any open change in the relationship. Although Thespiae maintained control over its own affairs, Thebes ensured that the government of the other city retained a particular form. These acts are that of an established dominant state towards its subject; tellingly, there is no mention of even token resistance actually occurring. The brevity of the description suggest that Thucydides found the event largely unremarkable, and even unimportant in the context of the Peloponnesian War. Such behaviour is to be expected of Thebes: here, Thucydides acknowledges with little hesitation Thebes' position as the

\footnotetext{
305 Buck (1994), 19, suggests that the destruction of walls also allowed easy access for federal hoplites; two instances of removing the walls (with Mycalessus, Thuc. 7.29.4) do not make a federal security programme, especially when both involve Thebes.

${ }^{306}$ See discussion in Camp (2000), 47-50, and Hansen and Nielsen (2004), 135-37.
} 
long-standing hegemon within Boeotia. The aggression here, however, perhaps allowed Thebes to gain effective control of another two $\mu \varepsilon \dot{\rho} \eta$ in the Confederation.

\section{THE LOCAL CONSTITUTIONS}

The Boeotian poleis all shared the same oligarchic constitution between 447 and 387 (Hell Oxy. 16.2). ${ }^{307}$ There is no indication that this was necessitated by the arrangements of the Boeotian Confederation. Although Thucydides referred to the "four councils of the Boeotians" (5.38.2), parallel to the four councils in each of the poleis, the confederate and local governments do not seem to have depended on each other. Indeed the Hellenica Oxyrhynchia explicitly distinguished the local, but parallel, governments from the confederate government in its description of constitutional affairs in Boeotia. The Confederate government probably had the same restricted franchise as the local oligarchies (cf. Hell. Oxy. 16.2), ${ }^{308}$ and the representatives to the Confederate government were probably selected by the local governments, but neither of these is incompatible with idiosyncratic local constitutions. There is no reason then that the members of the Confederation all needed to have the same constitution.

The circumstances of the foundation of oligarchies throughout Boeotia after Coronea are not clear. We must assume ex silentio that the oligarchic constitutions were established directly after Coronea: there is no direct evidence for constitutional reforms in Boeotia between 447 and $387 .{ }^{309}$ Obviously the restricted franchise benefited the oligarchs who had brought down the democracies. ${ }^{310}$ Prominent democrats, such as the Theban Ptoeodorus, seem to have gone into exile (Thuc. 4.76.2). Parallel oligarchic constitutions perhaps provided a necessary degree of stability for cooperation between Boeotian states. A long history of pro- and antioligarchic (or pro- and anti-democratic, or pro- and anti-Athenian/Spartan)

\footnotetext{
${ }^{307}$ Probably only the "sovereign" poleis, those named at the head of a $\mu \varepsilon \dot{\rho} \rho \varsigma$ (much the same list as at Thuc. 4.93): Bonner (1910), 406.

${ }^{308}$ Larsen (1968), 33-34, proposes that it was the hoplite or higher class, which would have left over half the citizen population disfranchised if Thucydides' enumeration of Boeotian forces at Delium (4.93.2) is any indication.

${ }^{309}$ Ténékidès' suggestion (1954), 71-72, that oligarchic government was part of the Boeotian $\pi \alpha ́ \tau \rho 1 \alpha$ is hopelessly primitivist. There is no clear evidence that the Boeotian consitutions before Oenophyta were all oligarchies.

${ }^{310}$ Cartledge (2000), 409.
} 
factionalism had been at the root of upheavals within various poleis, but they also affected interstate relations (cf. Hell. Oxy. 17.2). It is clear that factions with shared ideals cooperated across state borders; democracies neighbouring oligarchies destabilised oligarchic constitutions (and vice versa), providing support and if necessary a base of operations for disempowered discontents. Suppressing such factionalism helped to preserve the oligarchic ideals of the anti-Athenian rebels and of the Confederation as a whole.

Not every polis, however, participated so willingly in the revolt against Athenian occupation in 447 . Thespiae, for example, was not prominent in the revolt and was still accused of being pro-Athenian (i.e. pro-democratic) in 421. The oligarchic constitutions were greater impositions for some states than others, as the Athenianimposed democracies had been. Thebes, however, was aggressively involved in the establishment of the new oligarchies: Aristotle's statement (Pol. 1302b) about Theban dissolution of the Athenian-imposed democratic constitution does not necessarily mean that Thebes was the first Boeotian polis to revolt, but implied a degree of deliberate action in the establishment of a new constitution, which cannot be demonstrated for the other Boeotian poleis. Thebes played an active role in the formation of the oligarchic constitutions which were imposed on all Boeotian states in the late fifth century.

\section{THEBES, BOEOTIA AND THE PEACE OF ANTALCIDAS}

Clear condemnation of the Boeotian Confederation as an imperialist enterprise is delivered by the discourse preceding the settlement of the King's Peace or Peace of Antalcidas (the first of the attempts throughout the fourth century to establish a "common peace" in Greece, mooted 392-91, first executed in 386). ${ }^{311}$ Sparta, as $\pi \rho \circ \sigma \tau \alpha \dot{\tau} \eta \varsigma$, aggressively applied the terms of this common peace, asserting the autonomy ( $\alpha$ خovo $\mu$ í $\alpha$ ) of all Greek states; Boeotia was explicitly included in this rearrangement of Greek interstate relationships over the objections of the Theban

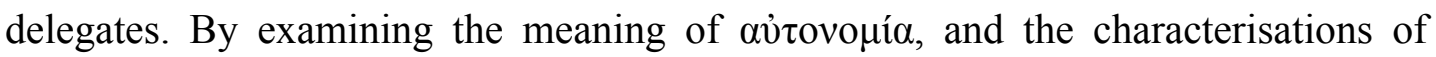
Xenophon and Andocides of Theban resistance to the terms of the Peace, it can be

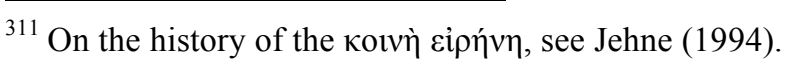


seen that the Spartan arrangers of the Peace problematised not Boeotian federalism, but Thebes' power within Boeotia, and identified the Boeotian Confederation as the mechanism by which Thebes was controlling other Boeotian poleis.

The common peace, by its ideology, encompassed all Greek poleis; the Boeotian Confederation was not singled out by the terms. The terms of the Peace, dictated by the Persian king Artaxerxes, required that all Greek poleis "be permitted to be autonomous", with certain substantial exceptions:

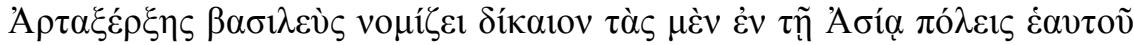

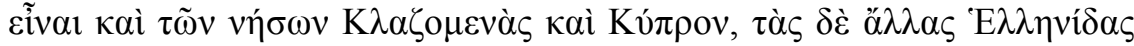

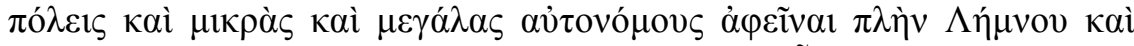

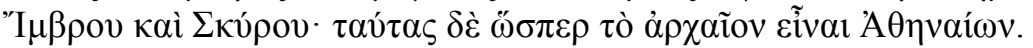

King Artaxerxes thinks that it is just that the cities in Asia should be his, and Clazomenae and Cyprus in the islands, but the other Greek cities both great and small should be permitted to be autonomous, except Lemnus, Imbrus and Scyrus; these should be the Athenians' as in the past. (Xen. Hell. 5.1.32)

The terms of the Peace are sweeping, and identify only relationships which are exempt (recognising, incidentally, that those poleis were not autonomous and would continue to be so). There is nothing which specifically marks the Boeotian Confederation or any other specific target. Hansen has argued that the literal sense of the main clause was so broad that it would have dissolved almost any interstate relationship within Greece not specifically identified as exempt. ${ }^{312}$ It was therefore a matter of interpretation, dependent largely on the $\pi \rho 0 \sigma \tau \alpha \dot{\tau} \eta \varsigma^{\prime}-$ i.e. Sparta's -

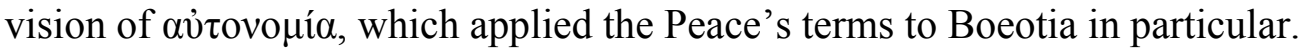

The critique of the Boeotian Confederation as a structure which diminished the autonomy of its members predated the peace conference of 386 by almost a decade. Lysander, standing beneath the walls of Haliartus in 395, during the early stages of the Corinthian War, first suggested that the Haliartians were oppressed; the Theban forces within the city immediately put down an apparently impromptu revolt:

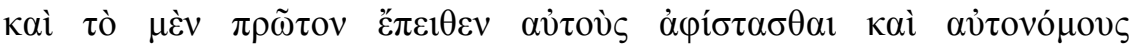

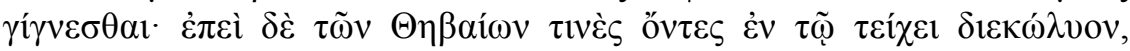

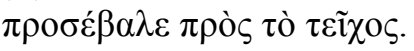

${ }^{312}$ Hansen (1995a), 28. 
Firstly he tried to persuade them to revolt and become autonomous. But when some of the Thebans who were inside the wall prevented them, he made an attack on the wall. (Xen. Hell. 3.5.18)

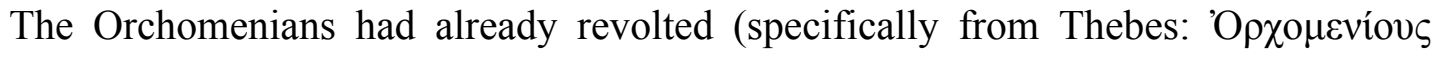

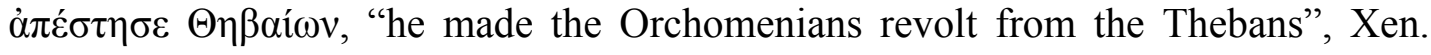
Hell. 3.5.6). ${ }^{313}$ With Orchomenians in Lysander's besieging force and Thebans inside Haliartus, the political situation leaves little doubt that Lysander envisioned a close relationship between Theban occupation and Haliartus' apparent lack of autonomy.

Spartan concerns must have been restated as part of the failed negotiations for common peace in 392-91, under the same general terms as finalised in 386. Andocides' On the Peace provides an insight into the debate which is largely ellipsed by Xenophon, and Boeotia's acquiescence (as Athenian allies in the Corinthian War) to the peace forms a major point of his rhetoric. He focuses solely on Orchomenus as the beneficiary of the autonomy clause:

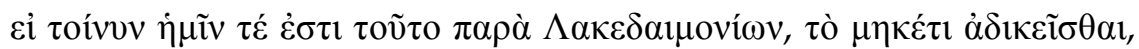

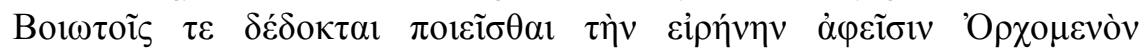

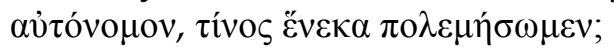

If then we are promised by the Lacedaemonians that we will no longer be mistreated, and the Boeotians have decided to set Orchomenus free and make peace, why should we fight? (Andoc. 3.13)

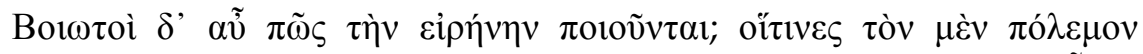

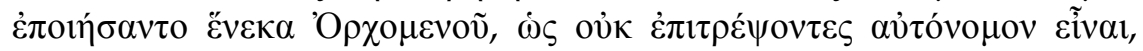

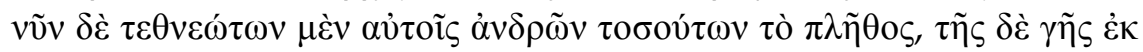

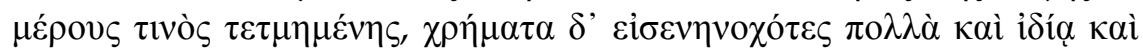

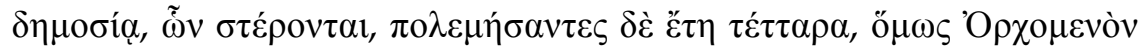

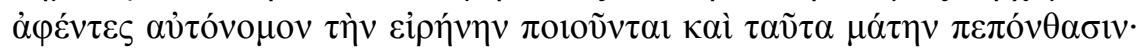

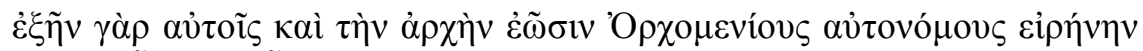

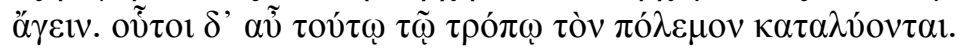

In what circumstances are the Boeotians making peace? They made war because of Orchomenus, so as not to give it up to being autonomous, but now with the majority of its men dead, and a large part of its territory devastated, having expended much money both public and private, which is wasted, they have fought for four years and nevertheless permit Orchomenus to be autonomous and make peace and have suffered these things in vain, for they could have left the Orchomenians autonomous at the beginning and made peace. In this way they are ending the war. (Andoc. 3.20)

${ }^{313}$ Buck (1994), 38. 
This does not necessarily imply that the Boeotian Confederation was offered an exception from the terms of the peace, as Athens and Persia were offered (limited) exceptions in $386 .{ }^{314}$ Orchomenus might have stood pars pro toto for all nonautonomous Boeotian poleis, as it was clearly the most vocal dissident. ${ }^{315}$ More importantly, Orchomenus had already plainly ceased to cooperate with the rest of the Boeotian Confederation and had asserted independent policies, but had only gained its $\alpha$ ¿ovoría more recently, and by explicit grant. ${ }^{316}$ Perhaps, as seems to have been the case in Haliartus, Orchomenus was subject to a Theban garrison.

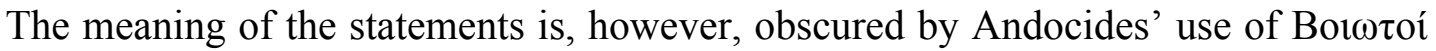
throughout the speech. This by no means indicates that the Boeotian Confederacy as a whole was willing to release Orchomenus: with no evidence for any reversion of the $\alpha \pi 0 \sigma \tau \alpha \sigma i \alpha$ of Orchomenus between 395 and 392, the proposed terms of the peace settle the ongoing question of Orchomenus' secession, already identified as “from Thebes" (Xen. Hell. 3.5.6, see above). Xenophon's concluding remarks about the effectiveness of the King's Peace repeat the same:

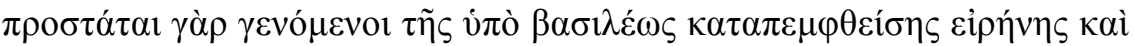

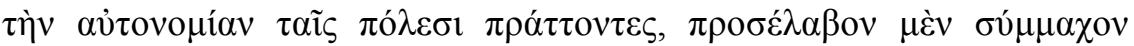

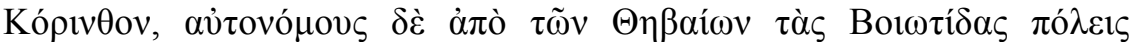

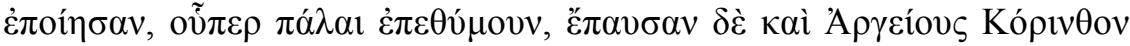

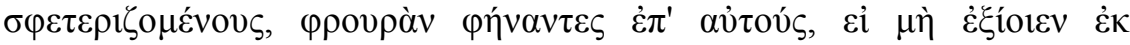
Kopívөov.

For having become protectors of the peace which had been ordained by the King and establishing the autonomy in the poleis, they gained an ally, Corinth, and made the Boeotian poleis autonomous from the Thebans, for which they had long been eager, and stopped as well the Argives from appropriating Corinth by threatening to set a guard against them, unless they left Corinth. (Xen. Hell. 5.1.36)

In light of the clear naming of Thebes, it is tenuous to suggest that the Spartan objection was to the concept of federalism. Andocides speaks in broader terms; Xenophon clearly indicates that Spartan concerns about Boeotian autonomy were directed at Thebes. It is disingenuous to suggest that Xenophon falsely presented

\footnotetext{
${ }^{314}$ Rhodes (1993), 170, suggests that Sparta did perhaps offer a full exception, which suggests that

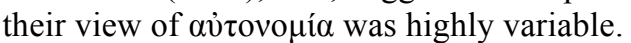

${ }^{315}$ Buck (1994), 53, argues that the faction of Leontiades was on the rise again at Thebes, and therefore sympathised with Orchomenus.

${ }^{316}$ Hansen (1996), 130, argues that Orchomenus was autonomous from 395; Andocides' view in 391 clearly suggests that some time had elapsed between the start of the war and the release of

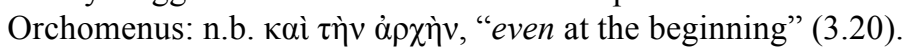


Thebes as Sparta's concern when the only other source, Andocides, does not in fact contradict him.

Thebes clearly conceded to the argument that the Boeotian states under the Confederation were not autonomous. Xenophon highlights, somewhat contrary to Andocides' account of the early negotiations, Theban reservations about the terms of the Peace in 391:

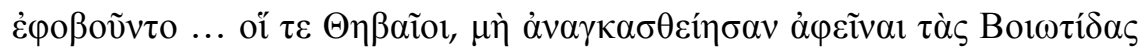

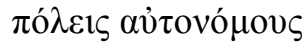

The Thebans, too, were afraid that they would be forced to allow the Boeotian poleis to be autonomous. (Hell. 4.8.15)

Fundamental to Theban fears is the admission that the Boeotian poleis could validly be identified as non-autonomous. Such fears confirm that not only Orchomenus was at stake in these negotiations. The Thebans made a token attempt again to resist the terms of the peace in 387 :

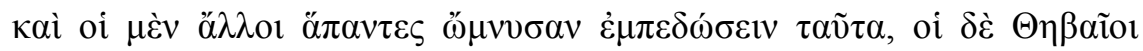

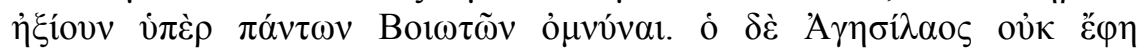

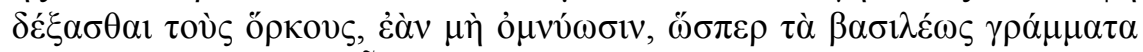

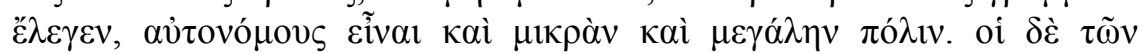

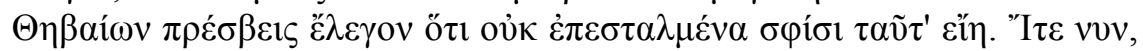

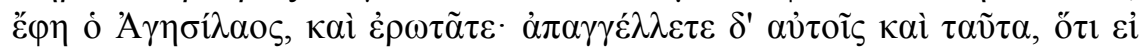

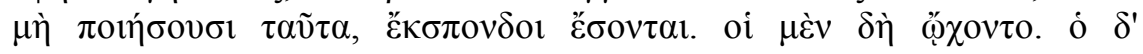

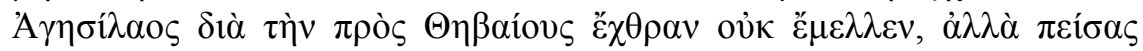

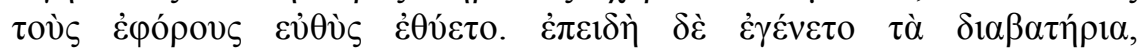

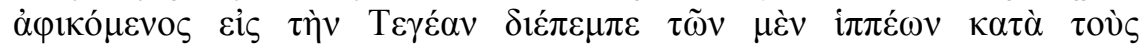

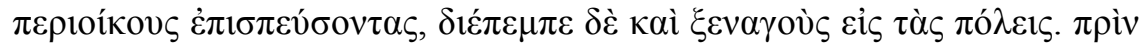

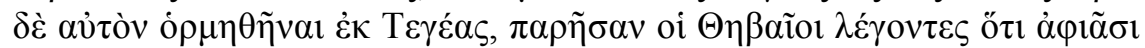

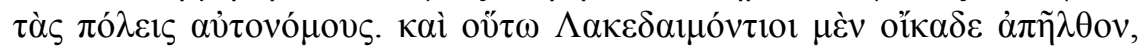

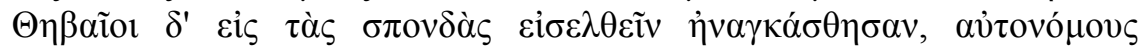

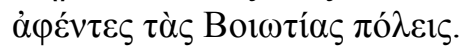

And all the other states swore to observe these terms, but the Thebans claimed the right to swear on behalf of all the Boeotians. However Agesilaus refused to accept their oath, unless they swore, just as the king's letter said, that any polis, small or great, would be autonomous. The Theban ambassadors said that this was not what they had been arranged to do. "Go now," Agesilaus said, "and ask. Announce this to them as well: that unless they do this, they will be outside the treaty." So they did go, but Agesilaus out of hatred for the Thebans did not wait for them, but persuaded the ephors and immediately made the sacrifices for war. When his offerings were favourable, he came to Tegea and sent around some horsemen to speed up the perioeci, and he also sent hiring agents to the cities. Before he could set out from Tegea, though, the Thebans arrived saying that they were releasing the poleis to autonomy. And thus the Lacedaemonians returned home, and the Thebans were 
forced to come into the treaty, leaving the Boeotian cities autonomous.

(Xen. Hell. 5.1.32-33)

The claim to the right to swear for all the Boeotians is an oddity. Cartledge has suggested that the Thebans in principle now saw the Boeotian states as a single polis. ${ }^{317}$ If Thebes now wished to present the Confederation as a new polis, it was not one which resulted from $\sigma 0 \mu \pi 0 \lambda \imath \tau \varepsilon i ́ \alpha$ : most telling was the (unstated) absence of any other Boeotian representatives at the peace conference. ${ }^{318}$ There is, however, no evidence for any wider discourse regarding merging Boeotian poleis. Quite aside from the continuing use of the plural poleis to refer to Boeotia, in discussions and elsewhere, Xenophon reports no actual attempt to justify Thebes' claim. In fact, the ambassadors' protestations that they had not been sent to swear the exact words of the autonomy clause of the treaty suggest that Thebes hoped (perhaps against hope) to swear to the peace without actually swearing to grant autonomy to the Boeotian states. ${ }^{319}$ The speedy acquiescence thereafter suggests that they had no particular rhetoric to defend their relationship with the Boeotian poleis. ${ }^{320}$ The Thebans acknowledged, as early as 392, that the Boeotian Confederation interfered with the autonomy of its other members, and that this was due to Thebes' construction of the Confederation.

It is important then to consider what exactly the principle of autonomy was, and how

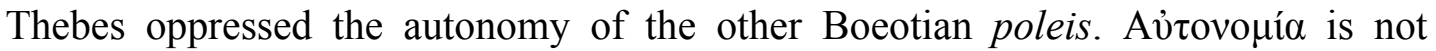

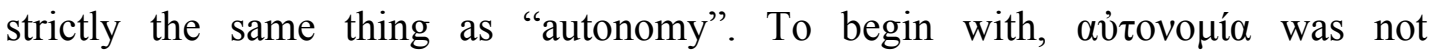

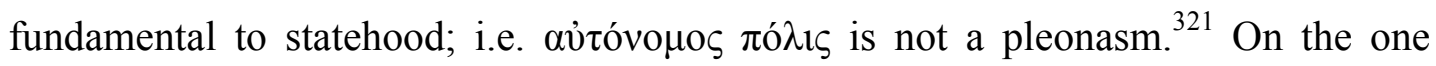

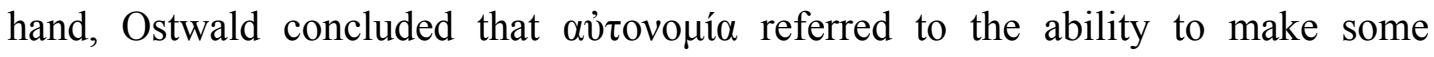
decisions, particularly internal ones, independently, and that the presence of a hegemon did not strictly interfere with the principle of autonomy. ${ }^{322}$ With such an

\footnotetext{
${ }^{317}$ Cartledge (1987), 379-80; Keen (1996), 114.

318 Hansen (1996), 128, notes that the appeal to swear for the Boeotians itself indicates Theban

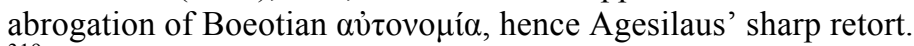

${ }^{319}$ As Hansen (1996) argues, the words of the oath themselves probably did not include the specific clauses, although it would have been high sophistry (or impiety: Keen [1995], 114) to avoid the clause on these grounds.

${ }^{320}$ Hansen (1996), 129, claims that the Thebans had nothing to fear if they believed the Boeotian

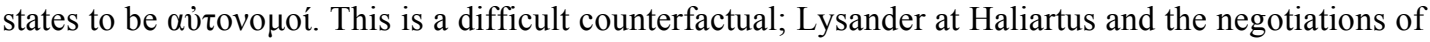

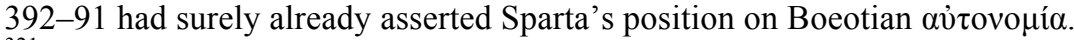

${ }^{321}$ Hansen (1995a), 21-43.

${ }^{322}$ Ostwald (1982).
} 
interpretation the condemnation of the Boeotian Confederation in the fourth century is a clear indication that Thebes was overreaching. On the other hand, Hansen has

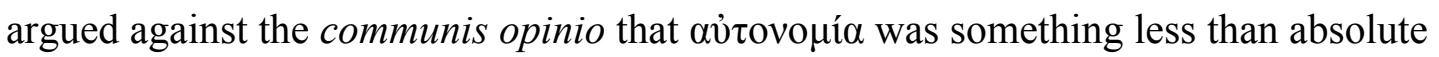
independence, particularly in the case of the King's Peace. ${ }^{323}$ However, the suggestion that "everybody seems to agree that autonomia is incompatible with being a member state of a federation" lacks evidence. ${ }^{324}$ The only examples which Hansen can adduce relate to Boeotia, and are insufficiently clear to define a principled juxtaposition of federalism and autonomy. The sources do not identify the cooperative aspect of Boeotian interstate relations as the problem. Autonomy was the sole cause of Spartan consternation. Our sources are more expansive on the application of autonomy to the other participants in the Corinthian War: the $\sigma 0 \mu \pi \mathrm{o} \lambda \iota \tau i \alpha_{\alpha}$ of Argos and Corinth, which Sparta classified as Argive "appropriation" of Corinth (Xen. Hell. 5.1.36, see above), is specifically addressed. In the second iteration of the Peace, in 371, the $\sigma 0 \mu \mu \alpha$ í $\alpha$ of the Second Athenian Confederacy was problematised (though the charter recognised members' autonomy). ${ }^{325}$ No more definitive issue is given in the consideration of Boeotia: Thebes oppressed the Boeotian states before the King's Peace; afterwards, it stopped. The internal process is hidden from history.

Analysis of Theban control of Boeotia as imperialist was persistent, and Xenophon clearly linked Thebes' treatment of Boeotia with Greek analysis of imperialism. In the Memorabilia, Xenophon presents a conversation between Socrates and Pericles the Younger, which includes the following characterisation of the relationship between Thebes and Boeotia:

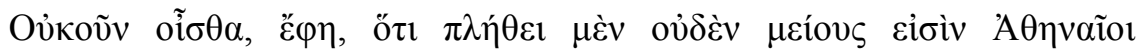

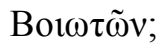

Oĩ $\delta \alpha \gamma \alpha \dot{\rho} \rho, \tilde{\varepsilon} \varphi \eta$.

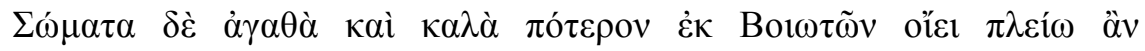

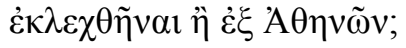

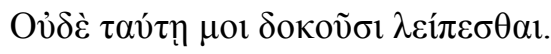

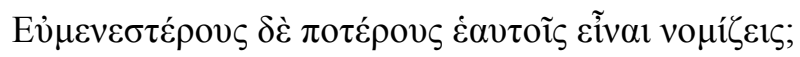

\footnotetext{
${ }^{323}$ Hansen (1995a).

${ }^{324}$ Hansen (1995a), 35.

${ }^{325}$ For the charter, see Diod. 15.28.4.
} 


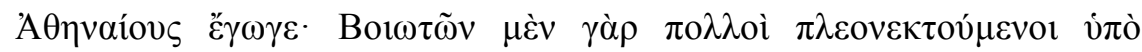

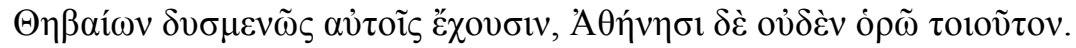

"Do you not think," he [Socrates] said, "that the Athenians are no less in numbers than the Boeotians?"

"I do," he [Pericles] said.

"And do you think that more noble and good bodies could be chosen from the Boeotians than the Athenians?"

"They do not seem to me to be left behind in that."

"Which do you think are more friendly to each other?"

"The Athenians, for my part; for many of the Boeotians, suffering from Theban greed, dislike them, while I see no such thing in Athens." (Xen. Mem. 3.5.2)

The term $\pi \lambda \varepsilon_{0} \operatorname{s\varepsilon \xi i\alpha ,~"greed",~is~a~matter~of~moral~philosophy,~although~it~is~not~at~all~}$ unusual in historiography. ${ }^{326}$ Plato's Gorgias makes evident the ties between the

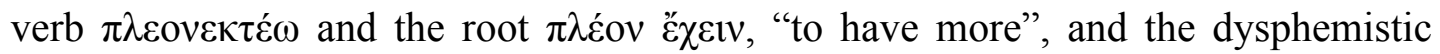
nature of this term: ${ }^{327}$

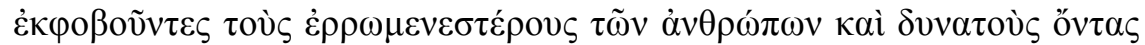

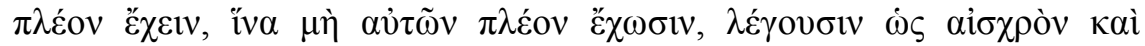

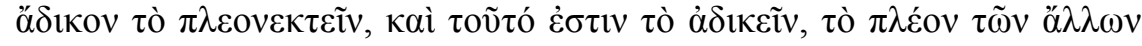

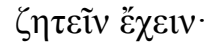

[The weak] frighten the stronger people and those able to have more, in order that they not get more than themselves; they say that it is shameful and unjust to be greedy, and that this is injustice, to seek to have more than others. (483c)

LSJ specifically glosses the Xenophontic passage as "being overreached or defrauded by" the Thebans. ${ }^{328}$ Balot, however, has demonstrated that greed was one of the moral underpinnings of Greek historical analysis of imperialism from the fifth century onwards. This appears throughout Herodotus, and very tellingly in

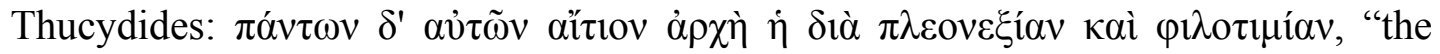
cause of all of this was rule for the sake of greed and ambition" (3.82.8, on Corcyra). ${ }^{329}$ At Athens, Pericles was a force of moderation. ${ }^{330}$

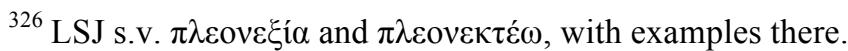

${ }^{327}$ See Balot (2001), 5-7, for an exegesis of greed in the Gorgias. Plato does continue to specifically link "having more" with "ruling" (483d).

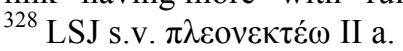

${ }^{329}$ See Balot (2001), ch. 4, on greed and imperialism in Herodotus, ch. 5 on Thucydides.

${ }^{330}$ Balot (2001), 172-73.
} 
It seems clear then that Xenophon's description of Theban "greed" was not an abstract or general critique of Thebes' treatment of Boeotia. In the scope of interstate relations "greed" or "the desire to have more" was an indicium of imperialist tendency; Xenophon uses terminology which implicitly compares Thebes with his own earlier discussion of Athenian greed and imperialism implicit in his attempts to disprove accusations of greed leveled at Socrates and to distance his mentor from the greedy imperialist Alcibiades. ${ }^{331}$

The supposed date of the conversation is unclear: Xenophon says only "once", $\pi$ o $\tau \varepsilon$ (3.5.1). The obvious terminus ante quem is Pericles the Younger's execution after the Battle of Arginusae; the suggestion at 3.5.4 that the Boeotians almost threaten to overrun Attica on their own power suggests a point in the Decelean War. However, it seems more likely that the conversation is a work of historical fiction which is not intended to really reflect an exact point in time. The passage in many ways seems to presuppose the political situation of the Theban hegemony after Leuctra; we might assume therefore that the passage was written after 371. However, in the use of Socrates and Pericles the Younger the passage clear allows us to see the discussion here as an analysis of Thebes' position in the Boeotian Confederation at the time of the Peloponnesian War. In the memory of the mid-fourth century, Thebes had been imperialist in the fifth century.

\section{CONCLUSION}

The weight of power was unambiguously given to Thebes in the supposedly equitable regional government of Boeotia in the mid-Classical period. Thebes held outright a near-majority of four divisions in the federal councils and the college of Boeotarchs. The attack on Thespiae in 423 may have been an attempt to coerce the Thespians into following Thebes more closely, giving it effective control over another two divisions. Everything about the structure of the Boeotian Confederation was designed to diminish opposition to Thebes' control, from the use of the Theban acropolis as the capital, to the division of representation in other poleis, to the oligarchic constitutions established in Boeotia after the Battle of Oenophyta.

${ }^{331}$ Balot (2001), 230-31. Xenophon also distances Socrates from Critias. 
Interference in internal affairs constitutes Finley's second criterion; Thebes moreover appropriated part of the local governments of the Boeotians to its own acropolis, as part of a federal government structure which was under its own control. The use of Boeotian troops throughout the period, often apparently under Thebes' command, was a form of economic exploitation (Finley's sixth criterion); the nature of payments to the federal treasury alluded to in the Hellenica Oxyrhynchia, and what they were used for, is too unclear to state with certain whether the fourth criterion, payment of 'tribute', was or was not true in Boeotia.

It is frequently held that the Boeotian confederation was a voluntary union. It might more accurately be described as one in which the members were not seen to object. The Hellenica Oxyrhynchia states only that "the entire évvo 6 was thus involved in

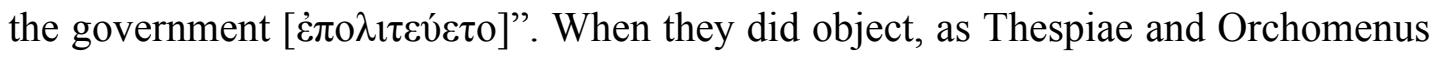
seem to have done, Thebes freely employed force in order to maintain its control. In the Corinthian War, Spartan rhetoric consistently objected to Thebes' relationship with the Boeotian poleis as interference in their autonomy. It is clear that it was this relationship, and not the concept of federal relationships, which Sparta found objectionable. Sparta aggressively campaigned to end Thebes' control of Boeotia, and ultimately succeeded. Perhaps due to Spartan rhetoric, Greek memory of the Classical Boeotian Confederation seems to identify Thebes as imperialist. 


\section{4}

\section{MAD HERACLES: THEBES AND BOEOTIAN COOPERATIVE COINAGE}

The coinage of Boeotia in most modern scholarship is intimately tied up with the discussion of the Boeotian Confederation. From the earliest issues it is clear that the Boeotian poleis did not mint their coinage entirely independently: in particular, the common weight standard and the shared iconography, particularly the so-called "Boeotian shield", indicate a monetary union in Boeotia. However, the numismatic evidence for Boeotia is so problematic that it must be treated carefully.

The dating of Boeotian coinage is notoriously difficult: ${ }^{332}$ the Boeotian poleis seem to have take to coinage with some gusto, producing over a hundred different coinage types in under two centuries. ${ }^{333}$ This is even more striking considering that almost every Boeotian coin bore the same shield symbol (the so-called "Boeotian shield") on one side; diversification was largely limited to the reverse. Find context has provided very little grounds on which to date the bredth of Boeotian coinage; Head's On the Chronological Sequence of the Coins of Boeotia (1881), which remains the standard (and most thorough) discussion of Boeotian coinage to date, dated the coins largely on stylistic grounds. Recent revisions have heavily condensed the earlier stages of Head's timeline, and suggested a number of simplifications. ${ }^{334}$ However, as Hansen has pointed out, Head's discussion especially of the chronology of coins was heavily influenced by his understanding of the historical situation in Boeotia, i.e. on non-numismatic evidence brought to bear on monetary evidence without any definite relationship between the two. ${ }^{335}$ Unlike Athenian coinage, there is no body of evidence from inscriptions or literary sources which relates to Boeotian coinage in this period. We cannot be confident about anything more than a very general progression of coin types. There is therefore an alarming tendency towards circular

\footnotetext{
${ }^{332}$ Larson (2007), 71-73.

${ }^{333}$ Head counts 81 different types of stater and drachma between the first issues and 379 (1881, 960), after which individual Theban magistrates seem to have taken on the responsibility of issuing coins for Boeotia, resulting in a large number of very similar issues (see Head 1881, 61-72).

${ }^{334}$ Larson (2007), 68-71.

${ }^{335}$ Hansen (2004), 432-33.
} 
or near-circular arguments on Boeotian history based on numismatic "evidence": for example, the Tanagran issues, noteably with both ethnic and civic inscriptions, ${ }^{336}$ have been taken as evidence for the rise (real or aspirational) of Tanagra in the second quarter of the fifth century: what evidence is there to date these coins apart from a little dubious literary evidence on Tanagra at the time? Hansen suggests that these, along with the so-called "independent issues" dated by Head to the period after the Peace of Antalcidas, were probably minted and circulated over a broader period than the precise dates suggested by Head.

Although it has long been recognised that the monetary evidence of Boeotia requires reevaluation, a full revision of the coinage remains to be done, and is beyond the scope of this thesis. For this reason, and considering the widely-acknowledged problems of numismatic evidence in general for historical analysis, I deviate from the typical approach of modern historians of Boeotia and consider Boeotian coinage on its own merits as much as possible. Here I will discuss mainly those things which can be firmly established from the coinage: the development of the Boeotian monetary union and the interpretation of the iconography.

\section{BOEOTIAN MONETISATION, CA. 525 BCE}

Between the explosion of coinage in Greece (ca. 550) and the end of the Archaic Period, ${ }^{337}$ Aeginetan coinage perhaps served as the common-use coinage within Boeotia. ${ }^{338}$ However in the second half of the sixth-century, Boeotian poleis began to issue their own coinage in a massive proliferation. ${ }^{339}$ For the most part, each polis produced its own coinage, bearing legends with the civic (usually abbreviated). However, all Boeotian coinage was produced on the same weight-standard as

\footnotetext{
${ }^{336}$ Boeotian coins sometimes bore the name of the polis, sometimes of the $\check{\varepsilon} \theta v o \varsigma$, sometimes both. In keeping with my general practice (see p. 3 n. 15), I refer to polis legends as civic, not ethnic, legends.

${ }^{337}$ On the date for the Greek adoption of coinage, see Schaps (2004), 93-96 (for a date ca. 620, based on electrum coinage from the Artemisium at Ephesus) and 101-102 (for a date in the early sixth century, based on the later Greek tradition of Pheidon of Argos as the inventor of coinage).

${ }^{338}$ Head (1881), 9. The two earliest known coin hoards from Boeotia $(I G C H 59,65)$, both from the mid-fourth century, predominately feature coins from the Boeotian poleis, but IGCH 59 also contains 34 Aeginetan staters, the heaviest representation by far of any non-Boeotian mint.

${ }^{339}$ Larson (2007), 68. Head's early sixth-century dating of the first Boeotian issues $(1881,3,9-12)$ is now widely rejected for a later date: Kraay (1976), 109; his thesis of a gradual development of issues, beginning with Tanagra, Thebes and Haliartus, although not accepted by Larson, still has some currency.
} 
Aeginetan coinage (a 6.2gm drachm). More significantly, although the Boeotian coin-types often bore some civic iconography, almost Boeotian coinage until the Hellenistic period bore on one side a distinctively-shaped shield, with the exception

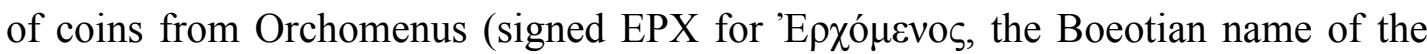
polis). Many types, assigned by Head to earlier periods, also bore an incuse mill-sail shape already well-known from the coinage of Aegina; in these types only the civic mint-mark indicated that the coins came from a particular polis.

The common characteristics of Boeotian coinage leave little doubt that the most of the Boeotians were in a monetary union from the very first issues. Overwhelmingly these have been used as evidence for the early Boeotian confederation. Mackil and Van Alfen have argued extensively that federal structures were just one possible reason for a monetary union; given that there is little other evidence for Boeotian confederation during the development of common Boeotian coinage, it is not necessarily true that the coinage reflects wider political organisation. ${ }^{340}$ This does not preclude the leadership of Thebes in monetisation. The motivation for beginning to produce local coinage is unclear: $^{341}$ it was perhaps the expression of a new federation, ${ }^{342}$ or a celebratory issue for the Pamboeotia festival held at the sanctuary of Athena Itonia. ${ }^{343}$

In either case it must be acknowledged that the coinage expressed Boeotian unity (whether forced or not); it is important to examine the use of iconography on these first issues, for even in the Archaic Period coinage was a prevalent resource ( $\chi \eta^{\prime} \mu \alpha \tau \alpha$ in Greek, which increasingly took on the meaning "money" in the Classical Period), ${ }^{344}$ and its circulation involved the daily reproduction of the issuing body's iconography. Coinage, perhaps more than any other common-use functional item in the Archaic and Classical Greek world, asserted the authority of the state; when this was not a polis but a super-civic body it was even more important to reassert a guarantor and testify to the weight-standard of the coinage.

\footnotetext{
${ }^{340}$ Mackil and van Alfen (2006), 202-3.

${ }^{341}$ The monetisation of Boeotia is a somewhat separate issue; many if not most Greek poleis began to issue their own coinage by the end of the Archaic Period, rather than rely on a flow of coinage from trade with other poleis.

${ }^{342}$ Head (1881), 10; Larsen (1968), 29.

${ }^{343}$ Larson (2007), ch. 3.

${ }^{344}$ Von Reden (2011), 6.
} 
Due to the lack of clear evidence for this early period, much of the discussion of the process by which Boeotian poleis began to mint similar coins locally must remain speculative. In this section, I attempt to establish a few possibilities based on the features of the coinage: firstly, I investigate the origins of the Aeginetan influence on the weight-standard and iconography, and the significance of shared coinage for Boeotian trade; secondly, I investigate the choice of iconography to represent Boeotia on its coinage. In both cases I argue that the influence of Thebes is clear. Thebes had the strongest ties to Aegina in the late Archaic period, while the socalled "Boeotian shield", which remained the symbol of Boeotian coinage for centuries, has the most indentifiable significance outside of coinage for Thebes.

\section{a. Aeginetan Influence and Boeotian Markets}

Greek tradition from the fourth century associated the invention of silver coinage with the rule of Pheidon of Argos, who in these tales (and only these tales) was also the ruler of Aegina. In this tradition, Aeginetans were the minters par excellence of the Archaic Aegean. ${ }^{345}$ It may be, as Head originally speculated, that Aeginetan experts were brought in to conduct the first issues of Boeotian coinage. ${ }^{346}$ There is no particular evidence for this apart from the Aeginetan characteristics on Boeotian coinage, but the use of the Aeginetan weight standard, the Aeginetan mill-sail incuse, ${ }^{347}$ and the turtle-ish shape of the Boeotian shield give the early issues a broadly Aeginetan flavour. ${ }^{348}$ These characteristics are enough to prompt investigation into the ties between Aegina and Boeotia in the period.

Head has speculated that Orchomenus was perhaps key to the involvement of Aeginetans in the first program: ${ }^{349}$ Strabo $(8.6 .3,14)$ attests that "Minyan Orchomenus", along with Aegina and five other poleis from the Saronic Gulf formed the amphictyony which governed the sanctuary of Poseidon on Calauria (off the coast of Troezen). Orchomenus was by far the most distant of these states, although

\footnotetext{
${ }^{345}$ Kagan (1960) is the classic discussion of the many issues with the story of Pheidon, not least is the exact date of his rule; see also Kagan (1982); Kroll and Waggoner (1984) are ill-convinced. Von Reden (2011), 71-72, on the significance of Aegina's role in trade.

${ }^{346}$ Head (1881), 10.

${ }^{347}$ See e.g. Seltman (1955), 38.

${ }^{348}$ Larson (2007), 75, who sees this as simply a matter of imitation.

${ }^{349}$ Head (1881), 9.
} 
the cult of Poseidon was prominent in Boeotia generally. ${ }^{350}$ However, Orchomenus' access to the sea, fairly essential for their involvement in the amphictyony, ended in the eighth century and has itself been used as a limit for the dating of the amphictyony. ${ }^{351}$ There must have been some form of contemporary contact, for the Orchomenian representation of the mill-sail developed as the Aeginetans changed the style of their incuse. ${ }^{352}$ Moreover, Orchomenus did not participate in the common issues of the Archaic Period; the independent Orchomenian series, without the Boeotian shield, is used as evidence for Orchomenus' non-participation in the confederation in general until after the Persian Wars. ${ }^{353}$

What is attested is a close relationship between Thebes and Aegina around the late sixth century. Herodotus claims that the Thebans sought out an alliance with Aegina in order to seek revenge on the Athenians in 506 (5.81-87). Aegina had a long history of rivalry with Athens and was a logical choice of ally for such a mission, but Herodotus makes no appeal to logic in his explanation: instead, he cites an

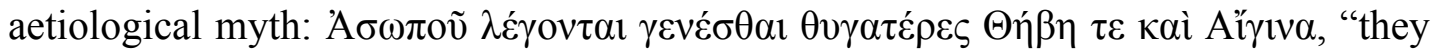
say that Thebe and Aegina are the daughters of Asopus [the deification of the river south of Thebes]" (5.80.1). This is not a purely Herodotean invention: the same myth is referred to by Pindar in his Isthmian 8 (ca. 478):

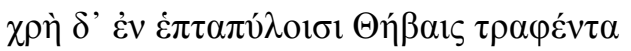

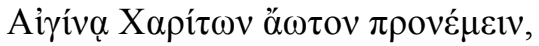

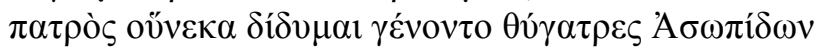

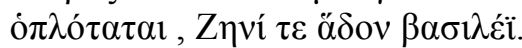
ô $\tau \alpha \grave{v} \nu \mu \grave{\varepsilon} v \pi \alpha \rho \grave{\alpha} \kappa \alpha \lambda \lambda \iota \rho o ́ \omega$

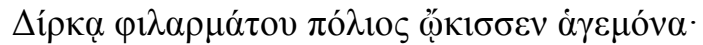

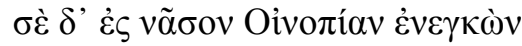

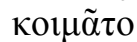

A man nursed in seven-gated Thebes to Aegina must offer first the Graces' flower; for they [i.e. the eponymous nymphs Thebe and Aegina] were twin daughters of one father, youngest of the Asopids; and they pleased king Zeus. One of these [Thebe] did he settle by Dirce's lovely waters, queen of this city of charioteers, but you [Aegina] he carried to Oenopia's isle and wedded." (Pind. Isthm. 8.16)

\footnotetext{
${ }^{350} C B$ 2:206-25 enumerates a number of sanctuaries to Poseidon in Boeotia.

${ }^{351}$ Breglia (2005).

${ }^{352}$ Head (1881), 9.

${ }^{353}$ Head (1881), 19-20.
} 
A special relationship between Thebes and Aegina would go some way to explaining the presence of Aeginetan symbols on Boeotian coinage. The myth of Thebe and Aegina is clearly propagandic. ${ }^{354}$ It is significant that in both Herodotus' story and Pindar's myth there is a clear directionality: the Thebans seek out the Aeginetans, the nymph Aegina was of Boeotian origin and taken away by Zeus to her island. In both cases the story tries to bring Aeginetan ties into Boeotia. Moreover, in Herodotus' tale Thebes does not initially understand the Pythia's reference to Aegina, instead assuming that it refers to her "usual allies": Aegina is therefore framed as a new contributor to the standing Boeotian community.

Literary evidence attesting to a popular recognition of links between Thebes and Aegina shortly after the time that Boeotian coinage develops suggests that the Aeginetan features of Boeotian coinage were at least active imitation, if not the full participation speculatively suggested by Head. If we recognise the Aeginetan features in Boeotian coinage, then it is important to note that the links known to us are specifically between Thebes and Aegina. This suggests that Thebes took an active role in the creation of Boeotian coinage.

The common weight standard of Boeotian coinage allowed for the seamless replacement of Aeginetan coinage with local coinage of the same standard. The reasons for the monetary union are, like much of the cooperation, obscure, but it seems highly unlikely that the coinage was produced for the taxation or recompensation in the federal government. ${ }^{355}$ However, we can suggest that it created a common market of tender: as long as every polis accepted that the coins of its fellow poleis were minted to the same standards, the coinage was largely interchangeable between the neighbouring states of Boeotia. ${ }^{356}$ Such an economic commune was highly unusual in the Archaic Period: in particular, it is worth noting that all the regions near Boeotia (with the exception of Delphi) employed different standards, thus requiring at least mathematical if not more physical exchange of

\footnotetext{
${ }^{354}$ Demand (1982), 29, argues that the poem reflects Thebes' post-war attempts to reestablish old political relationships, cf.

${ }^{355}$ Pace Mackil and Van Alfen (2006), 223-24.

${ }^{356}$ Von Reden (2011), 20, notes that a common weight standard was atypical of the central and northern Greek $\varepsilon ै \theta v \eta$.
} 
coinage. ${ }^{357}$ The strategy of adaptating weight standards to encourage trade between particular areas in the Archaic Period is suggested by the reports that Solon reformed Athens' weight standards in the very early sixth century ([Arist.] Ath. Pol. 10). ${ }^{358}$ Thebes, positioned at the crossroads of the passages between southern and northern Greece and the inland road from Tanagra and Euboea, would have profited most from an invigoration of internal Boeotian trading. The use of Aeginetan weight standards may also have opened up trade with other Aeginetan-standard areas.

\section{b. The Boeotian Shield}

With the sole exception of Orchomenus' issue, ${ }^{359}$ all Boeotian issues until the midfifth century adopted the same type, with a distinctively-shaped shield on the obverse, almost circular with semi-circular openings at the mid-point of the flat rim on either side, and an Aeginetan mill-sail incuse on the reverse (see Figure $2 \mathrm{a}-\mathrm{f}$ ). ${ }^{360}$

The distinctively-shaped shield has been so strongly associated with Boeotia that shields of this type in modern scholarship are generally referred to as "Boeotian shields", even when the shield is largely devoid of Boeotian context. There is no evidence from the ancient world which associated the Boeotians with a particular shield-type $;^{361}$ it is possible that this is the shield which was called "ox-hide", $\beta$ ov $\varsigma$ or ßocín in Homer, for the presumed material of the shield. ${ }^{362}$ Indeed, the shield of Ajax fashioned by a (Boeotian?) man from Hyle is described as a tower shield:

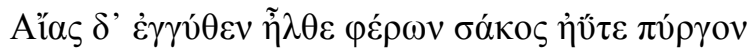

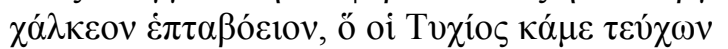

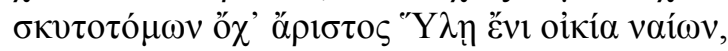

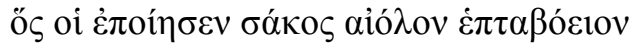

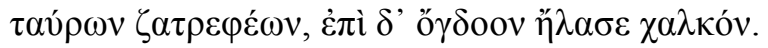

Ajax approached, holding his shield, like a tower, bronze and seven oxhides, which Tychius labored upon for him, by far the best leathercutter in his house, in Hyle, who made for him the brilliant shield

\footnotetext{
${ }^{357}$ See Von Reden (2011), 206-8, for a categorisation of Archaic issues by weight standard.

${ }^{358}$ Von Reden (2011), 65-66.

359 See Head (1881), 9 and 19, on the different iconography of Orchomenus' first issue, which is usually cited as evidence of Orchomenus' abstention from the Archaic phase of the Boeotian League (see Larsen [1968], 28-29).

${ }^{360}$ Head (1881), 11-12, 14-17; Seltman (1955), 54-55; Kraay (1976), 108-109. See p. 3 n. 15 on the terminology "obverse" and "reverse".

${ }^{361}$ Larson (2007), 80-93.

${ }^{362}$ Larson (2007), 78-79.
} 
from seven hides from fat bulls, and upon it he drew an eighth layer of bronze. (Il. 7.220-25)

Why was this shield chosen as the iconographic representation of Boeotia for their first issue of coinage? Civic issues from the Archaic Period invariably chose images which were distinctive symbols of the particular polis: the Athenian owl and helmeted woman's head on the Archaic Owls together could only denote Athens' patron goddess and namesake, but these worked together and were accompanied by the civic legend $\mathrm{A} \Theta{ }^{363}$ The Boeotian shield coinage lacks even an explanatory legend; the only symbol apparently unique to Boeotia was the shield. A pragmatic consideration may have influenced the choice of image; the oval shield with its flat rim and points at the openings was much the same shape as the Aeginetan turtle. ${ }^{364}$

Many coins of this series bear one of a variety of initialisms usually interpreted as the mint-mark of an individual polis, although the modern scholarly difficulty of assigning mint-marks to poleis suggests that this system was either haphazard and prone to overlapping mint-marks or understood in a system which is not known to us. A distinguishing mark was not effective if it could not be understood to distinguish (see Figure $2 \mathrm{~b}$ and $\mathrm{e}$, signed with the closed eta, for either Haliartus or Hyettus). ${ }^{365}$ It is possible that two-letter mint marks were deployed in order to solve ambiguity; unabbreviated legends did not appear until the fourth century. ${ }^{366}$ The most common finds of the series which bears the Boeotian shield and Aeginetan mill-sail, however, were without legend. Head identifies these as Theban issues, ${ }^{367}$ although the mint-mark of a cross-barred theta is usually identified as representing Thebes. ${ }^{368}$

Earlier scholars suggested that the shield was perhaps intended to represent the shield of Athena Itonia, whose sanctuary near Coroneia was the site of the

\footnotetext{
${ }^{363}$ Kraay (1976), 60-63.

${ }^{364} \mathrm{Cf}$. Head (1881), 9, who draws a similar parallel between the shape of the Orchomenian corn and the Aeginetan turtle.

${ }^{365}$ Ashton (1995), 11-15.

${ }^{366}$ See Larson (2007), 68-69 n. 6, on reattribution work.

${ }^{367}$ Head (1881), 10; Kraay (1976), 109.

${ }^{368}$ As Larson (2007), 68, points out, it could also represent Thespiae.
} 
Pamboeotian Games in the Hellenistic Period. ${ }^{369}$ The nature of the Pamboeotia being sufficiently archaic to posit a beginning much earlier than its first attestation, ${ }^{370}$ it is possible that the earliest issues of Boeotian coinage not only represented the shield of Athena Itonia, but were issued in by various Boeotian states as a celebration of the festival. However, the antiquity of the games should not be overestimated: Pindar

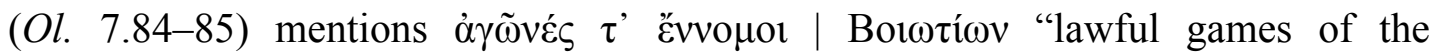
Boeotians" in the early fifth century, but this follows directly on from a description of the prizes in Arcadia and Thebes: we should not be overly confident in reading the brief $\tau \varepsilon$ as a disjunction; ${ }^{371}$ a fragment of a Partheneia ( $f r .94 b .43-48$ Race) mentions victories in horse races at the temple of Poseidon at Onchestus and the temple of Itonia near Coronea:

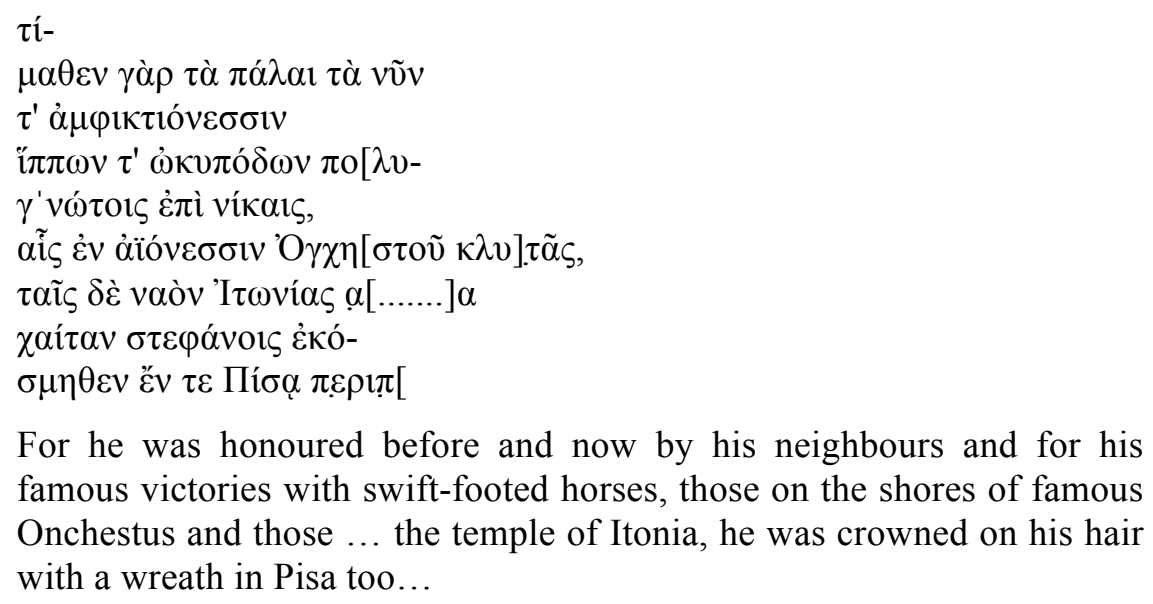

For he was honoured before and now by his neighbours and for his famous victories with swift-footed horses, those on the shores of famous Onchestus and those ... the temple of Itonia, he was crowned on his hair with a wreath in Pisa too...

This confirms that games were conducted at two different Boeotian sancutaries. These are not securely pan-Boeotian in character: the victor celebrated in Olympian 7 was Diagoras of Rhodes! It should be noted in particular that the secure evidence for the Pamboeotia coincides with the use of the sanctuary of Athena Itonia as the capital of the Boeotian League, having replaced the Cadmea at Thebes in the later fourth century ( $I G \mathrm{ix}^{2}$ 1.170, SEG 18.240; cf. Hell. Oxy. 16.4, which places Boeotian federal councils on the Cadmea). ${ }^{372}$ It is therefore somewhat tenuous to suggest that the games at the sanctuary of Athenian Itonia were so important in the sixth century

\footnotetext{
${ }^{369}$ Head (1911), 343; Seltman (1955), 55; contra, Lacroix (1958), 7; On the Pamboeotian games, see Strab. 9.411.

${ }^{370}$ Buck (1979), 88-89.

${ }^{371}$ Roesch (1975), 6; Robert (1979), 208-10.

${ }^{372}$ See $C B$ 1:123 for discussion of the inscriptions. Polybius (4.3.5) directly attests the existence of the Pamboeotia in the 220s.
} 
as to prompt the beginnings of Boeotian minting. The conjunction of (Hellenistic) Boeotian federal activity and Boeotian ethnic activity is cause for caution: we cannot be completely confident that the councils were removed to a sanctuary which already had federal significance.

The use of divine imagery on coinage was not unusual; as von Reden points out, a supernatural figure was a useful guarantor of coinage, ${ }^{373}$ and this must have been even more true for a coinage which was apparently shared in common between a number of poleis, and therefore (perhaps) accepted as fiduciary coinage beyond the borders of the issuing polis on a regular basis. We should not, however, ignore the distinction between a depiction of the god him- or herself and a symbol of the god. Nor can we conclusively link the Boeotian shield with Itonia: while Athena is generally armed, and her shield plays a significant part in both descriptions and depictions of Athena, she is not depicted with this shield. ${ }^{374}$ An early Boeotian lekane (c. 550-500 BCE; British Museum B80) appears to depict Athena at her altar, awaiting a sacrifice: she holds a shield aloft, but even in profile it does not have the

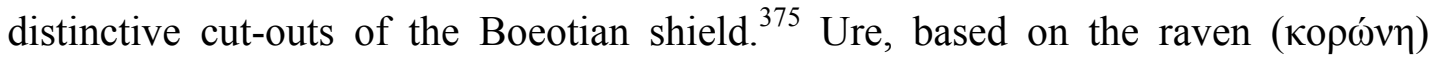
which accompanies her suggested that this was in fact a depiction of Itonia from Coronea. ${ }^{376}$ Other contemporary depictions identified as showing the Itonian rites likewise lack the Boeotian shield. ${ }^{377}$

Lacroix maintains that the shield on the reverse of Boeotian coinage is an ox-hide shield and a reference to the folk etymology of Boeotia from ßoṽ s (cattle). ${ }^{378}$ However, there is no evidence that the Archaic Boeotians actually identified their ethnic with the word for cattle. ${ }^{379}$ The use of this pun might have been reinforced by

\footnotetext{
${ }^{373}$ Von Reden (2011), 156.

${ }^{374}$ Larson (2007), 80.

${ }^{375}$ CVA 24930; $C B$ 1:122.

${ }^{376}$ Ure (1929), 170; see also $C B$ 1:122 n. 3.

377 See $C B$ 1:122 and nn. 5-6.

${ }^{378}$ Lacroix (1958).

${ }^{379}$ Euripides, in the the fragmentary Melanippe Bound (before 411) provides Athenian evidence for

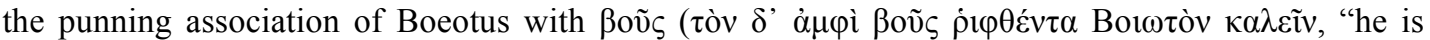
called Boeotus for he was cast amongst the cattle", fr. 489); we might note that the Athenians devoted some effort to Boeotia-related humour, while Pindar's famous reference is not to Boeotian cattle but pigs (see p. 115).
} 
a secondary pun, for in Homer oxen were used as the standard measure of value. ${ }^{380}$ However, there seems to have been little afterlife for the Homeric agricultural value system: the vocabulary of coinage from the very earliest stages focuses on utensilbased metaphors (ỏßo $\lambda o i ́, \delta \rho \alpha \chi \mu \alpha i) .{ }^{381}$

Punning coins appear in some few poleis at the end of the Archaic Period: Larson cites examples from Phocaean, Melian, and Selinuntine coinage. ${ }^{382}$ Although the use of punning iconography is attested contemporary with the first Boeotian issues, the puns employed require very little direct interpretation, e.g. seal $=\varphi \omega ́ \kappa \eta=$ Phocaea Reading the Boeotian shield as a pun requires shield $(\neq \dot{\alpha} \sigma \pi i \varsigma / \sigma \alpha ́ \kappa о \varsigma)=\beta$ osí $=\beta$ oṽ $\varsigma$ $\approx$ Boeotia. The particular difficulty of the last equivalence is demonstrated by Antagoras of Rhodes' attempt to make Boeotia a pun on a cow's ear (oũ, stem $\grave{\omega} \tau$-) instead. ${ }^{383}$ The pun is further strained by employing the shield, rather than an ox head, as the reference. ${ }^{384}$

If the shield on Boeotian coinage is not the symbol of the patron goddess of Boeotian unity, nor a pun on the name "Boeotia", where did it come from? There is good literary evidence to suggest that the shield was a significant symbol, not of Boeotia, but one which was associated more heavily with Thebes and its inhabitants. ${ }^{385}$ The Cadmeians are described as $\varphi \varepsilon \rho \varepsilon \sigma \sigma \alpha \kappa \varepsilon ́ \alpha \varsigma$ "sakos-bearing" in the Shield of Heracles ([Hes.] Asp. 13), a poem of potentially Boeotian origins, if not strictly Theban. ${ }^{386}$ In a version of the Heraclean myth which emphasised his Theban origins rather than the Argive, the Shield as a whole focuses on the depiction of the

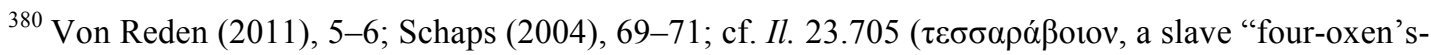

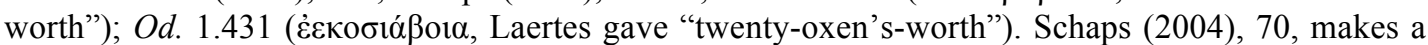
distinction between worth and market value; in light of this distinction it does not necessarily follow that the ancient Greeks would have understood a link between monetary objects and Homeric forms of estimating value.

${ }^{381}$ Schaps (2004), 82-88.

${ }^{382}$ Larson (2007), 79, esp. n. 61.

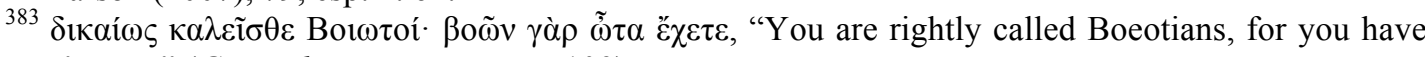
cow's ears." (Gnomologium Vaticanum 109)

${ }^{384}$ Larson (2007), 79.

${ }^{385}$ contra Larson (2007, 80-104), whose discussion largely ignores the Theban rather than generally Boeotian origin of her exempla.

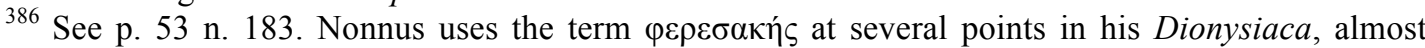
undoubtedly in response to its use here: the Theban context, at least, holds; likewise P. Berol. 5226v.
} 
shield of the hero Heracles. ${ }^{387}$ This shield is referred to as a oókoৎ throughout the poem, which suggests not a round shield (as Lacroix asserted) but a body shield. ${ }^{388}$ Lacroix rejected the association with Heracles' shield on the dubious grounds that Heracles is not consistently depicted with a shield in the Boeotian shape in depictions of the fight with Cycnus which is the subject of the poem. ${ }^{389}$ The shield is also frequently invoked in Attic tragedy when referring to Theban military force. ${ }^{390}$

Coinage was not high art but a highly functional item; its iconography needed to be understood at a glance by the general populace. It is therefore worth drawing on popular versions of myth and its associations for the interpretation of coinage iconography, rather than (albeit debatably) prestige items such as individual vases. Martin has recently argued that the Shield is representative of a popular tradition of epic; ${ }^{391}$ likewise tragedy in its initial performances appealed to a broad (in the case of the Great Dionysia, even Panhellenic) audience. There is very little evidence to associate the particular shield-type with collective Boeotian identity. Considering the relationship between Thebes and Aegina which is attested soon after the first Boeotian coins, the association between Thebans and shields is more informative.

\section{FEDERAL COINAGE}

In the mid and late fifth century and early fourth century, the monetary union of Boeotia continued. A single very brief statement in the Hellenica Oxyrhynchia attests to a possible use for cooperative coinage, in order to pay federal councillors, but on the whole there is still little evidence to relate them to the political situation. The legends on Tanagran coins from the mid-fifth century have been interpreted by Fowler as evidence of Tanagran ambitions to hegemony in this period. However, the evidence is circumstantial; the most we can contend is that the coins were patriotic. However, Theban coins of the late fifth century seem to have dominated Boeotia monetarily. These were bore distinctive symbols of Thebes. In particular, the use of

\footnotetext{
${ }^{387}$ Head (1881), 10, did acknowledge the possibility that the shield was Heracles' and had its origins in Theban cult;

${ }^{388}$ Asp. 139, 334, 363, 455, 460. The title, which may be later, is Aspis: see Bershadsky (2011) on the possible equivalence of the two terms. Larson (2007), 80; contra Lacroix (1958), 15.

${ }^{389}$ Lacroix (1958), 10.

${ }^{390}$ Aspidephoros: Aesch. Septem 13; Eur. Supp. 390; Bacch. 781; of Argives, Aesch. Ag. 825.

${ }^{391}$ Martin (2005).
} 
Heracles in arms may have been an iconographic reference to Theban domination of Orchomenus.

\section{a. So-Called Tanagran Hegemonic Issues}

On the basis of an unusual series of coins bearing both the mint mark of Tanagra (TA) and an ethnic inscription (BOI), Head and Fowler have suggested that Tanagra took (or aspired to take) Thebes' position of authority in the Boeotian League in the twenty three years between the end of the Persian Wars and the Battle of Oenophyta; ${ }^{392}$ Fowler states that these coins, "unique in their double inscriptions, are unmistakable evidence that Tanagra... at the time claimed leadership of the League." 393 The interpretation, however, relies on an unsupportable precise dating of the coins to this period. I have already considered the issues in an optimistic reading of Thucydides' account of Oenophyta and the presumption of a power vacuum in Boeotia. ${ }^{394}$

Head placed the Tanagran coins at the start of the Classical Period, after a break in minting, making Tanagra the first Boeotian city to issue coins in the post-war period. $^{395}$ These new types from Tanagra largely resemble the Archaic type, but sometimes replaced the mill-sail incuse with a four-spoked wheel, perhaps borrowed from the coin-types of the near-by Euboean polis Chalcis. ${ }^{396}$

Fowler bases her interpretation heavily on the significance of the double inscription on Tanagran coinage: it is true that these issues alone bear both a civic and an ethnic inscription, and were the first issues to bear an ethnic inscription at all. That this represents a claim to leadership of the federation, however, is a stretch. There is no comparative evidence to assert that the combination of two inscriptions was an aggressive move, and no clear indication at all that Tanagra made any other claims to a strong position within Boeotia. ${ }^{397}$ We might more readily attribute the double

\footnotetext{
${ }^{392}$ Head (1881), 20-23, first proposed the idea that the coins represented Tanagran ambition.

${ }^{393}$ Fowler (1957), 166.

394 See p. 71.

${ }^{395}$ Head (1881), 20-23. See Kraay (1976), 110 n. 1, on the difficulties of dating these Tanagran types, although he accepts Fowler's (and by extension Head's) dating.

${ }^{396}$ Head (1881), 20-23; Seltman (1955), 57; Kraay (1976), 110. On the relationship between Tanagran and Euboean coinage, see Seltman (1955), 57; Fowler (1957), 167 n. 9.

397 contra Fowler (1958).
} 
inscription to ethnic pride at a time when Boeotia as a whole was diminished, and remember Tanagra was perhaps amongst the first to adopt the unifying iconography in the sixth century. ${ }^{398}$ Seltman suggests that Tanagra, with its harbour and connection to Euboea, perhaps represented the financial capital of Boeotia, and therefore the polis with the most pressing need for coinage. ${ }^{399}$ Larson suggests that these may have been festival coins. ${ }^{400}$ The Gorgoneion sometimes used on these coins would suggest a festival for Athena Itonia, possibly the Pamboeotia.

\section{b. Theban Federal Issues}

In the later fifth century, the plain decoration of the earliest issues was replaced by a proliferation of much more individualistic types, dated to the assertion of Athenian hegemony over Boeotia after Oenophyta $(457-447),{ }^{401}$ which employed local iconography-although these replaced not the Boeotian shield but the Aeginetan mill-sail incuse. ${ }^{402}$ The profusion of new styles has been interpreted as evidence for a break-down of the Boeotian Confederation, ${ }^{403}$ but given the dubious evidence for the existence of the Archaic Confederation (as argued in chapter two), and the likelihood that the dates of these issues are broader than the ten-year period of Athenian hegemony, we should acknowledge equally with the changed types the continuities of weight standard and the Shield obverse type which indicate the continuation of a unifying sentiment in Boeotia at the time.

Thebes seems to have been the only polis in Boeotia to issue coinage for the later half of the fifth century. ${ }^{404}$ The numerous series of coins produced were decisively Theban: although the coins all bear, as we would by now expect, the Boeotian shield, the coins bore the civic legend, and the reverse types represent three categories of Theban myth. ${ }^{405}$ These types were much more elaborate than the earlier Theban issues, with depictions of Heracles in a variety of mythical scenes (in

\footnotetext{
${ }^{398}$ Head (1881), 11.

${ }^{399}$ Seltman (1955), 55

${ }^{400}$ Larson (2007), 73.

${ }^{401}$ See Thuc. 1.108, 4.95.

${ }^{402}$ Kraay (1976), 110-11.

${ }^{403}$ Kraay (1976), 110-12. Contra, Buck (1979), 148, who argues that the continuity of the shield suggests that the union was not disestablished after 457.

${ }^{404}$ Head (1881), 30-33; Seltman (1955), 156; Kraay (1976), 111.

${ }^{405}$ See Head (1881), 30-42; Kraay (1978?), 111, describes these as "the most original designs ever produced in Boeotia". They clearly represent the Theban cultural floruit of the late fifth century.
} 
combat, with his bow, removing the Delphic tripod, strangling serpents, see Figure $3 \mathrm{~b}-\mathrm{e}$ ), the eponymous nymph Thebe seated on a throne (see Figure $3 \mathrm{f}$ ) and profile heads of Dionysus and Heracles. ${ }^{406}$ These were undeniably propagandistic, focused on promoting Thebes' hegemony within Boeotia through Theban iconography.

The Theban chauvinism of the coins is remarkable given that these coins seem to have replaced the wide proliferation of Boeotian coinage from the period of the Athenian hegemony (457-447 BCE). The use of Heracles as the most frequent symbol is particularly aggressive considering the mythical relationship between the Theban hero Heracles and King Erginus of Orchomenus. ${ }^{407}$ These were for everyday use, and must have circulated fairly widely around Boeotia. The imagery appealed to the violent myth of Theban subjugation of Orchomenus, a fairly threatening piece of iconography.

There was no pressing need for every city in Greece to mint coins on its own behalf, and the Theban coinages of this period do seem to be federal issues, and therefore open to the rest of Boeotia. Coinage must have been required by the individual poleis, who paid a per diem to the councillors which they sent to Thebes (Hell. Oxy. 16.4). ${ }^{408}$ However, we do not know how the process of minting for the Confederation worked: did individual states provide silver to the Theban mint to be coined? This was an unusual situation if so: particularly those cities which had already been responsible for their own minting presumably had not lost the technology.

Perhaps more likely is that Thebes minted silver (and, late in the period, gold) coins which were then bought by the other Boeotian poleis. Demand for Boeotian coinage may well have been high, as those who served on the various councils of the Boeotian Confederation were paid. Theban control over Boeotian coinage therefore

\footnotetext{
${ }^{406}$ Kraay (1976), 111, separates the profile heads into a distinct series, slightly later than the earlier types; I will treat them together here, as they generally part of the same coinage scheme. The Thebe coins represent two different types, sometimes interpreted as Thebe and Harmonia (Cadmus' wife), but see Kraay (1976), 111 n. 2.

${ }^{407}$ See pp. 40-44, and Demand (1982), 48-52, on the popularity of Heracles at Thebes in the fifth century.

${ }^{408}$ They may also have paid their hoplites, as they did in the later fourth century: Mackil and Van Alfen (2006), 223.
} 
becomes a mark of Theban imperialism within Boeotia: in order for the states to finance their representatives within the Boeotian government individual poleis were forced to trade with Thebes. Such monetary control was of course not unknown in the late fifth century, as Athens famously required its imperial subjects in the islands to pay their tribute in Athenian Owls. ${ }^{409}$ This may constitute another form of Theban economic exploitation of Boeotia in the Classical Period.

\section{CONCLUSION}

Boeotian coinage was a monetary union; its relationship to the political situation of Boeotia in the Archaic Period and early fifth century must be drawn with caution by historians, for there is no historical evidence regarding Boeotian monetisation. The argument that Tanagra aspired to take leadership of Boeotia from Thebes relies too heavily on the circumstantial evidence of a dubious dating of a coin (which while innovative was not aggressive) with the presence of Spartans near Tanagra in 457. The historical casuations of Boeotian monetisation are unrecoverable. The evidence of the coins themselves, however, suggests that the coins were intended to create a trade union within Boeotia, and they seem to have borne, as a long-standing Boeotian symbol, a distinctive shield shape which is more easily related to Thebes than to Boeotia.

By the late fifth century, we can observe that the Theban coinage, which seems to have been the most prevalent in this period, bore symbols of Theban patriotism which were often rather aggressive in their nature. Rather than bearing an ivywreathed amphora (see Figure 3a), or the head of a god or hero, they bore images of the Theban hero Heracles prepared for battle. Given the likelihood that these coins circulated around Boeotia, the use of a Theban hero who was associated in myth with the conquest of another Boeotian polis must have been a startling threat. It is possible as well that the Theban coins were the only federal coins produced in this period, although this relies on the dubious evidence of dating. If this was so, then the Thebans, like Athens, may have compelled the other Boeotian states to use its own coinage, for money was a necessary part of the Confederation.

\footnotetext{
${ }^{409}$ Kraay (1976), 70-71.
} 

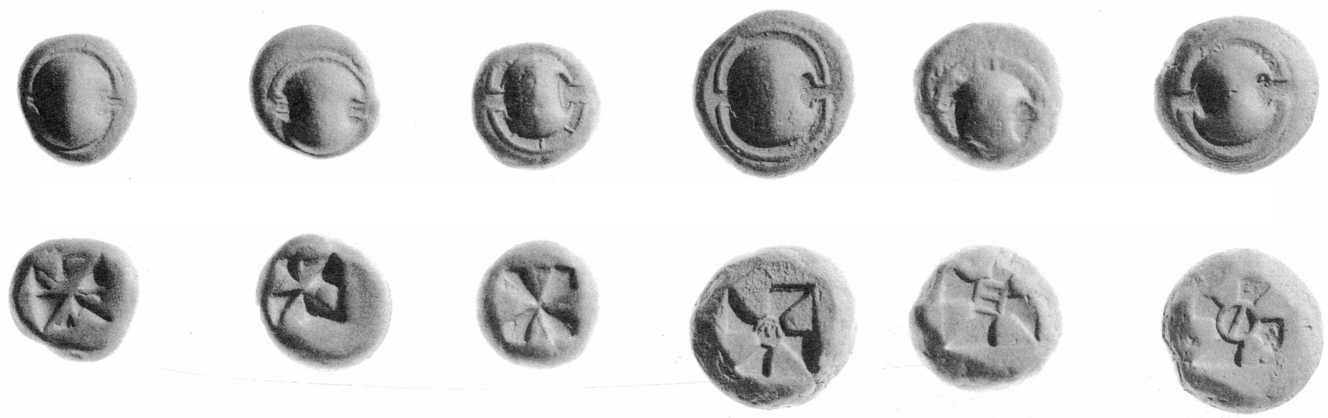

Figure 2: The earliest coins

From left to right: a: Tanagra; b: Haliartus; c: unsigned (Thebes?); d: Mycalessus; e: Haliartus; f: Pharae. a-b: signed obverse in recesses of shield; $\mathbf{d}-\mathbf{f}$ : signed reverse in centre of mill-sail. Kraay (1976), pl. 19, nos. 338-343.
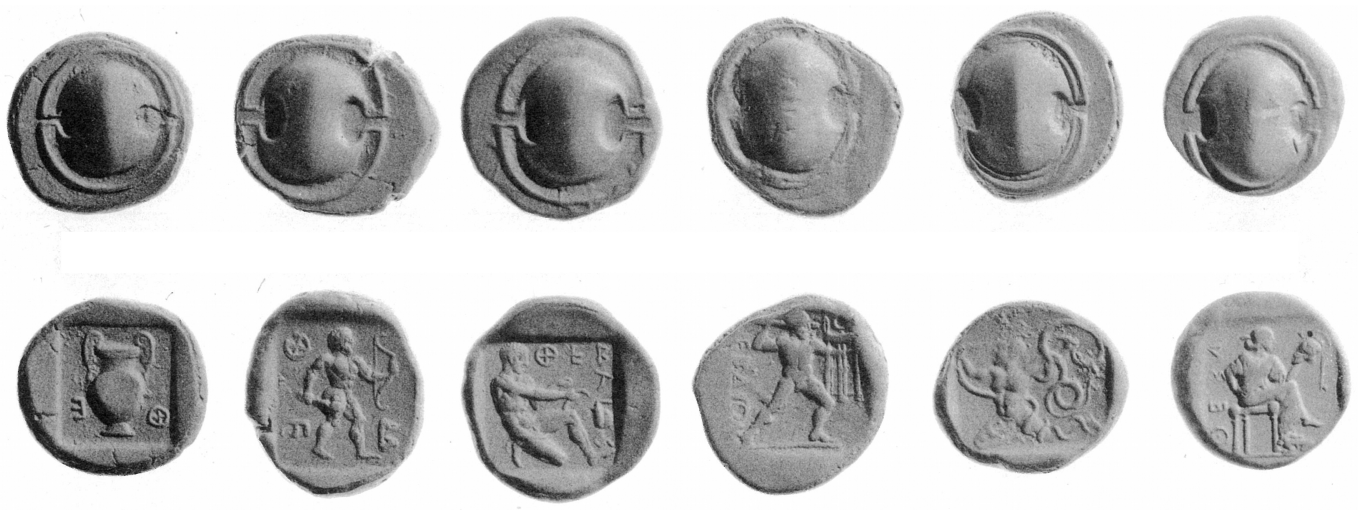

Figure 3: Theban coins, late fifth century?

From left to right: a: amphora, period of Athenian hegemony; b: Heracles in combat; c: Heracles with bow; d: Heracles with tripod; e: infant Heracles strangling serpents; f: Thebe/Harmonia seated. All signed $\Theta E B[A]$ reverse. Kraay (1976), pl. 19, nos. 350-355. 


\section{CONCLUSION}

Thebans appropriated Boeotian identity in the late sixth century. By 479, Thebes had been at the core of four different "Boeotian actions" in twenty years, and asserted leadership of a substantial group of Boeotian poleis. The military cooperation in this group was, it seems, not bound by any formal agreement but by an unwritten rule of international relations. The nature of this leadership is unclear: the military aspect suggests that Thebes was a hegemon, but Theban rhetoric in the late fifth century implied a metropolis relationship with the rest of Boeotia. This same rhetoric appealed to a much stronger relationship than the military unity suggested in our sources. Historiographical sources frequently acknowledged the separate existence of the Boeotian states, but Thebes was continuously singled out as the leader of this group. At the same time, the development of Boeotian coinage reflected an almost region-wide cooperation, but the Boeotian coins bore Theban symbols. By the time of the Persian Wars, Theban aristocrats considered themselves responsible for Boeotia's welfare. It seems probably that Thebes was in control of Boeotian poleis' foreign relations at this time and led the Boeotian states, with the notable exception of Thespiae and Plataea, into Medism.

In the fifth century, Boeotia arose from the apparent depressions of the Persian Wars and Athenian control to construct a formal and enduring relationship between the Boeotian states, with an independent regional government. There is little historiographical evidence to support Buck's argument that Orchomenus and not Thebes led Boeotia in the development of the Boeotian Confederation; by the beginning of the Peloponnesian War, Thebes was clearly in control of the Confederation. Although the Boeotian government in theory employed a system of proportional representation, Thebes held the most substantial portion of this representation and may have moved to take an outright majority in its attack on Thespiae. The practical evidence of the Boeotian League demonstrates Thebes' control, and suggests that the threat of force was also employed to keep the other Boeotian states in line. This threat is reflected in the iconography of Theban coinage of the late fifth and early fourth century, which includes many types which reflect the Theban and anti-Orchomenian hero Heracles in battle panoply. 
The international reaction to the Boeotian Confederation, particularly in the context of the Peace of Antalcidas, clearly saw Thebes as the controlling element of Boeotia. Spartan rhetoric from the Battle of Haliartus, at the start of the Corinthian War, referred to Boeotia's loss of autonomy and encouraged "rebellion" from Thebes in Boeotia. Only under the threat of Spartan action were the Thebans forced to admit that their position in Boeotia abrogated the Boeotian poleis' autonomy. Xenophon, writing later in the fourth century, characterised Thebes' treatment of Boeotia as $\pi \lambda \varepsilon 0 v \varepsilon \xi i$ í a word which was used in historiography to characterise imperialistic movements. The breadth of Theban control of other Boeotian states is affirmed by the characterisation of the relationship as imperialist.

As I have argued, there is very little evidence that any Boeotian state acted independently of Thebes in the period between ca. 525 and 386. Those few exceptions - Plataea and Thespiae in the fifth century, and Orchomenus in the fourth century - are clearly presented as exceptions to the rule and their actions often resulted in attempts at retribution from Thebes. Thebes' control of the Boeotians was persistant and regularly backed by force or the threat of force. The degree of violence and the domains of control which are evidenced in our sources align with Finley's typology of imperialism.

One of the conclusions which has arisen from the work of the Copenhagen Polis

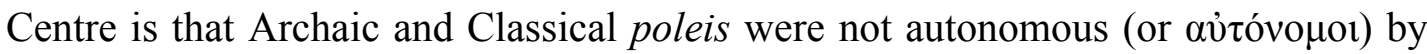
definition. ${ }^{410}$ This leaves us with a much broader scope for discussing unequal relationships between Greek states than has previously been allowed: the term hegemonic has been employed to describe Thebes, but this does not adequately encompass Thebes' systematic violence towards Boeotian states, nor the degree of influence and sometimes outright control which it exercised over the Boeotian poleis between the late sixth century and the Peace of Antalcidas. I have tried to use imperialism here as a spectrum, rather than an absolute, to fill the gaps in the current analysis of Classical Boeotian history. Champion complained quite recently that the

${ }^{410}$ Hansen (1995a). 
concept of imperialism was overused by historians, ${ }^{411}$ but a systematic approach to the relationships between small and great poleis is still lacking.

Although we cannot observe the substance of Thebes' motivations due to the nature of our sources, we can see a potential motivation. The benefits which Thebes reaped from Boeotia should not be underestimated. Epameinondas famously won the Battle of Leuctra by deploying an incredibly deep line of troops. This was a repeat of Pagondas' tactic at the Battle of Delium in 424: Thucydides' description of the Boeotian battle line (Thuc. 4.93.4) makes it clear that Pagondas was only able to form such a line, twenty-five men deep, because he had the full array of Boeotian troops to fill out the rest of the line. The same use of Boeotian troops seems to have made Thebes' victory at Leuctra, and therefore Theban hegemony throughout Greece, possible.

${ }^{411}$ Champion (1999), 87. 


\section{WORKS CITED}

Amit, Moshe. 1971. "The Boeotian Confederation During the Pentecontaetia". Rivista storica dell'antichità 1: 49-64.

-1973. Great and Small: A Study in the Relations Between the Great Powers and the Small Cities in Ancient Greece. Latomus 134. Bruxelles: Latomus.

Andreiomenou, Angheliki. 1989. "Böotien in der Zeit von 1050-800 v.Chr.". In Beister and Buckler eds. (1989), 253-64.

Andrewes, A. 1978. “Spartan Imperialism?” In Garnsey and Whittaker eds. (1979), 91-102.

Anson, Edward M. 2009. "Greek Ethnicity and the Greek Language". Glotta 85: 530.

Aravantinos, V.L. 2006. “A New Inscribed Kioniskos from Thebes”. BSA 101: 36977.

Ashton, R.H.J. 1995. "Pseudo-Rhodian Drachms from Central Greece". Numismatic Chronicle 155: 1-20.

Badian, Ernst. 1989. "Plataea between Athens and Sparta: In Search of Lost History". In Beister and Buckler eds. (1989), 95-112.

Bakhuizen S.C. 1989. "The Ethnos of the Boeotians". In Beister and Buckler eds. (1989), 65-72.

. 1994. "Thebes and Boeotia in the Fourth Century B.C." Phoenix 48.4: 30730.

Balot, Ryan K. 2001. Greed and Injustice in Classical Athens. Princeton, NJ: Princeton University Press.

Baragwanath, Emily. 2008. Motivation and Narrative in Herodotus. Oxford: Oxford University Press.

Bauslaugh, Robert A. 1991. The Concept of Neutrality in Classical Greece. Berkeley: University of California Press.

Beck, Hans. 1997. Polis und Koinon. Untersuchungen zur Geschichte und Struktur der griechischen Bundesstaaten im 4. Jahrhundert v. Chr. Historia Einzelschrift 114. Stuttgart: Franz Steiner.

Bederman, David J. 2001. International Law in Antiquity. Cambridge: Cambridge University Press.

Behrwald, Ralf. 2005. Hellenika von Oxyrhynchos. Darmstadt: Wissenschaftliche Buchgesellschaft. 
Beister, Harmut. 1989. "Hegemoniales Denken in Theben”. In Beister and Buckler eds. (1989), 131-54.

Beister, Hartmut, and John Buckler (eds.) 1989. Boiotika: Vorträge vom 5. Internationalen Böotien-Kolloquium: Institut für Alte Geschichte LudwigMaximilians-Universität München 13.-17. Juni 1986. Munich: Editio Maris.

Bershadsky, Natasha. 2010. "The Unbreakable Shield: Thematics of Sakos and Aspis". C Phil. 105.1: 1-24.

Bonner, Robert J., and Gertrude Smith. 1945. "Administration of Justice in Boeotia". C Phil. 40.1: 11-23.

Bowen, A.J. 1992. Plutarch: The Malice of Herodotus. Warminster: Aris \& Phillips.

Breglia, Luisa. 2005. "The Amphictyony of Calaureia". Ancient World 36.1: 18-33.

Bruce, I.A.F. 1967. An Historical Commentary on the "Hellenica Oxyrhynchia". London: Cambridge University Press.

. 1968. "Plataea and the Fifth-Century Boeotian Confederacy". Phoenix 22.3: 190-99.

Buck, Carl Darling. 1955. The Greek Dialects: Grammar, Selected Inscriptions, Glossary. Chicago: University of Chicago Press.

Buck, Robert J. 1972. "The Formation of the Boeotian League". C Phil. 67.2: 94101.

- 1979. A History of Boeotia. Edmonton: University of Alberta Press.

_. 1993. "The Outbreak of the Boiotian War". In Fossey ed. (1993), 91-99.

-1994. Boiotia and the Boiotian League, 432-371 B.C. Edmonton: University of Alberta Press.

Buckler, John. 1980. The Theban Hegemony, 371-362 BC. Cambridge, Mass: Harvard University Press.

Buckler, John, and Hans Beck. 2008. Central Greece and the Politics of Power in the Fourth Century BC. Cambridge, UK: Cambridge University Press.

Buckley, Terry. 1996. Aspects of Greek History, 750-323 BC: A Source-Based Approach. London and New York: Routledge.

Bull, Hedley. 1977. The Anarchical Society: A Study of Order in World Politics. New York: Columbia University Press.

Bury, J.B. 1959. A History of Greece to the Death of Alexander the Great, third edition. London: Macmillan. 
Cain, Peter J., and Mark Harrison (eds.) 2001. Imperialism: Critical Concepts in Historical Studies. London and New York: Routledge.

Camp II, John McK. 2000. "Walls and the Polis". In Flensted-Jensen, Nielsen and Rubinstein eds. (2000): 41-51.

Cartledge, Paul. 2000. "Boiotian Swine F(or)ever?: The Boiotian Superstate 395 BC”. In Flensted, Nielsen and Rubinstein eds. (2000), 397-418.

Cassio, Albio Cesare. 2009. "The Language of Hesiod and the Corpus Hesiodeum". In Montanari, Rengakos and Tsagalis eds. (2009), 179-202.

Cawkwell, G.L. 1972. “Epaminondas and Thebes”. CQ 22.2: 254-78.

Champion, Craige B. 2009. "Imperial Ideologies, Citizenship Myths, and Legal Disputes in Classical Athens and Republican Rome". In A Companion to Greek and Roman Political Thought, edited by Ryan K. Balot, 85-99. Malden: Blackwell.

Cloché, Paul. 1952. Thèbes de Béotie, des origines á la conquête romaine. Namur: Secrétariat des publications, Facultés universitaires.

Collard, Christopher, and Martin Cropp. 2008. Euripides: Fragments, volume 1. Cambridge, MA: Harvard University Press.

Davies, John K. 1994. "On the non-usability of the concept of 'sovereignty' in an ancient Greek context”. In Foresti et al. eds. (1994), 51-65.

Demand, Nancy. 1982. Thebes in the Fifth Century: Heracles Resurgent. London: Routledge.

De Romilly, Jacqueline. 1963. Thucydides and Athenian Imperialism, translated by Philip Thody. Oxford: Blackwell.

Debnar, Paula Arnold. 1996. "The Unpersuasive Thebans (Thucydides 3.61-67)". Phoenix 50.2: 95-110.

Desborough, Vincent Robert d'Arba. 1964. The Last Mycenaeans and their Successors: An Archaeological Survey c. 1200-c. 1000 B.C. Oxford: Clarendon Press.

Develin, R. 1990. "Numeral Corruption in Greek Historical Texts". Phoenix 44.1: $31-45$.

Diamant, Steven. 1982. "Theseus and the Unification of Attica". In Studies in Athenian Epigraphy, History and Topography, presented to Eugene Vanderpool, 38-47. Hesperia Supplement 19. Princeton: American School of Classical Studies at Athens.

Doyle, Michael W. 1986. Empires. Ithaca, NY: Cornell University Press. 
Ducat, Jean. 1973. "La Confédération béotienne et l'expansion thébaine à l'époque archaïque". $B C H$ 72: 59-73.

Dull, Clifford John. 1976. "A Study of the Leadership of the Boeotian League from the Invasion of the Boiotoi to the King's Peace". PhD diss., University of Wisconsin-Madison.

Ebbott, Mary. 2010. "Error 404: Theban Epic Not Found". Trends in Classics 2.2: 239-58.

Eckstein, Arthur M. 2006. Mediterranean Anarchy, Interstate War, and the Rise of Rome.

Edwards, Anthony T. 2004. Hesiod's Ascra. Berkeley: University of California Press.

Ehrenberg, Victor. 1969. The Greek State, second edition. London: Methuen.

Ferguson, William Scott. 1913. Greek Imperialism. Boston: Houghton Mifflin.

Fibiger Bang, Peter, and C.A. Bayly (eds.) 2011. Tributary Empires in Global History. New York: Palgrave Macmillan.

Fine, John V.A. 1983. The Ancient Greeks. Cambridge, MA \& London: Belknap.

Finkelberg, Margalit. 2005. Greeks and Pre-Greeks: Aegean Prehistory and Greek Heroic Tradition. Cambridge: Cambridge University Press.

Finley, M.I. 1959. The Greek Historians: The Essence of Herodotus, Thucydides, Xenophon, Polybius. New York: Viking Press.

. 1972. "Introduction". In Thucydides: History of the Peloponnesian War, translated by Rex Warner [1954], 9-32. London: Penguin.

_. 1978a. "Empire in the Greco-Roman World". Greece \& Rome 25.1: 1-15.

1978b. "The Fifth Century Athenian Empire: A Balance-Sheet". In Garnsey and Whittaker eds. (1978), 103-126.

Flensted-Jensen, Pernille, Thomas Heine Nielsen and Lene Rubinstein (eds.) 2000. Polis \& Politics: Studies in Ancient Greek History. Copenhagen: Museum Tusculanum.

Flower, Michael A., and John Marincola. 2002. Herodotus: Histories Book IX. Cambridge: Cambridge University Press.

Foresti, Luciana Aigner, Alberto Barzanò, Cinzia Bearzot, Luisa Brandi and Giuseppe Zecchini (eds.) 1994. Federazioni e federalismo nell'Europa antica: Bergamo, 21-25 settembre 1992. Milan: Università Cattolica del Sacro Cuore. 
Fossey, John M. 1988. Topography and Population of Ancient Boeotia. Chicago: Ares.

(ed.) 1993. Boeotia Antiqua III: Papers in Boiotian History, Institutions and Epigraphy in Memory of Paul Roesch. Amsterdam: J.C. Gieben.

Foster, Edith. 2010. Thucydides, Pericles and Periclean Imperialism. Cambridge: Cambridge University Press.

Fowler, Barbara Hughes. 1957. "Thucydides 1.107-108 and the Tanagran Federal Issues". Phoenix 11.4: 164-70.

Funke, Peter (n.d.), "Boeotia, Boeotians", in Brill's New Pauly, edited by Hubert Cancik and Helmuth Schneider. http://referenceworks.brillonline.com/ entries/brill-s-new-pauly/boeotia-boeotians-e218930

Garnsey, Peter, and C. R. Whittaker (eds.) 1979. Imperialism in the Ancient World: the Cambridge University Research Seminar in Ancient History. Cambridge: Cambridge University Press.

Georgiádou, Aristoúla. 1996. "Pro-Boiotian Traditions in the Fourth Century BC: Kallisthenes and Ephoros as Ploutarkhos' Sources in the Pelopidas". In Boeotia Antiqua VI: Proceedings of the $8^{\text {th }}$ International Confederence of Boiotian Antiquities (Loyola University of Chicago, 24-26 May 1995), edited by John M. Fossey, 73-90. Amsterdam: J.C. Gieben.

Giovannini, Adalberto. 2007. Relations entre états dans la Grèce antique: du temps d'Homère à l'intervention romaine (ca. 700-200 av. J.-C.) Historia Einzelschrift 193. Stuttgart: Franz Steiner.

Glotz, G. 1908. "Le conseil fédérale des Béotiens”. BCH 32: 271-78.

Gomme, A.W., A. Andrewes and K.J. Dover. 1945-81. A Historical Commentary on Thucydides, five volumes. Oxford: Clarendon Press.

Gray, Vivienne. 1989. The Character of Xenophon's Hellenica. London: Duckworth.

Grote 1907 Grote, George. 1869. A History of Greece: From the Earliest Period to the Close of the Generation Contemporary with Alexander the Great. London: Murray.

Gruen, Erich S. 1984. The Hellenistic World and the Coming of Rome. Berkeley: University of California Press.

Gschnitzer, F. 1955. "Stammes- und Ortsgemeinden in alten Griechenland". Wiener Studien 68: 120-44.

1960. Gemeinde und Herrschaft: von den Grundform griechischer Staatsordnung. Graz: Hermann Böhlaus. 
Guillon, Pierre. 1963. Études béotiennes: le Bouclier d'Héraclès et l'histoire de la Grèce centrale dans la période de la première guerre sacrée. Aix-enProvence: Faculté des Lettres.

Hall, Jonathan M. 1997. Ethnic Identity in Greek Antiquity. Cambridge: Cambridge University Press.

. 2000. "Sparta, Lakedaimon and the Nature of Peroikic Dependency". In Further Studies in the Ancient Greek Polis, edited by Pernille FlenstedJensen, 73-89. Historia Einzelschrift 138. Stuttgart: Franz Steiner.

_ 2002. Hellenicity. Chicago: University of Chicago Press.

- 2007a. "International Relations". In The Cambridge History of Greek and Roman Warfare, volume one, edited by Philip Sabin, Hans van Wees and Michael Whitby, 85-107. Cambridge: Cambidge University Press.

. 2007b. "Polis, Community and Ethnic Identity". In The Cambridge Companion to Archaic Greece, edited by H.A. Shapiro, 40-46. Cambridge: Cambridge University Press.

Hammond, Mason. 1948. "Ancient Imperialism: Contemporary Justifications". Harvard Studies in Classical Philology 58/59: 105-161.

Hammond, N.G.L. 1976. Migrations and Invasion in Greece and Adjacent Areas. Park Ridge, NJ: Noyes Press. 2000. "Political Developments in Boeotia". CQ 50.1: 80-93.

Hansen, Mogens Herman. 1995a. "The 'Autonomous City-State'. Ancient Fact or Modern Fiction". In Studies in the Ancient Greek Polis, edited by Mogens Herman Hansen, 21-44. Historia Einzelschrift 95.

1995b. "Boeotian Poleis: A Test Case". In Sources for the Ancient Greek City State, edited by Mogens Herman Hansen, 13-63. Acts of the Copenhagen Polis Centre 2. Copenhagen: Kongelige Danske Videnskabernes Selskab.

1996. "Were the Boiotian Poleis Deprived of Their Autonomia?" In Hansen and Raaflaub eds. (1996), 127-136.

1997. "The Polis as an Urban Centre: The Literary and Epigraphical Evidence". In The Polis as an Urban Centre and as a Political Community, edited by Mogens Herman Hansen, 9-86. Acts of the Copenhagen Polis Centre 4. Copenhagen: Kongelige Danske Videnskabernes Selskab.

. 2004. "Boiotia". In An Inventory of Archaic and Classical Poleis, edited by Mogens Herman Hansen and Thomas Heine Nielsen, 431-461. Oxford: Oxford University Press. 
Hansen, Mogens Herman, and Thomas Heine Nielsen. 2004. "Introduction". In An Inventory of Archaic and Classical Poleis, edited by Mogens Herman Hansen and Thomas Heine Nielsen. Oxford: Oxford University Press.

Hansen, Mogens Herman, and Kurt Raaflaub (eds.). 1996. More Studies in the Ancient Greek Polis. Historia Einzelschrift 108. Stuttgart: Franz Steiner

Harding, Philip. 1987. "The Authorship of the Hellenika Oxyrhynchia". Ancient History Bulletin 1: 101-104.

- 2007. "Local History and Atthidography". In A Companion to Greek and Roman Historiography, volume one, edited by John Marincola, 180-88. Malden, MA and Oxford: Blackwell.

Harris, William V. 1979. War and Imperialism in Republican Rome, 327-70 B.C. Oxford: Clarendon Press.

Head, B.V. 1881. On the Chronological Sequence of the Coins of Boeotia. London: Rollin and Feuardent.

-1911. Historia Nummorum, second edition. Oxford: Clarendon Press.

Hope Simpson, R., and J.F. Lazenby. 1970. The Catalogue of Ships in Homer's Iliad. Oxford: Clarendon Press.

Hornblower, Simon. 2002. "Herodotus and His Sources of Information". In Brill's Companion to Herodotus, edited by Egbert J. Bakker, Irene J.F. De Jong and Hans van Wees, 373-386. Leiden: Brill.

Hornblower, Simon. 1991-2008. A Commentary on Thucydides, three volumes. Oxford: Clarendon Press.

How, W.W., and J. Wells. 1912. A Commentary on Herodotus with Introduction and Appendices, two volumes. Oxford: Clarendon Press.

Janko, Richard. 1988. Homer, Hesiod and the Hymns: Diachronic Development in Epic Diction. Cambridge: Cambridge University Press.

Jehne, Martin. 1994. Koine Eirene: Untersuchungen zu den Befriedungs und Stabilisierungsbemuhungen in der griechischen Poliswelt des 4. Jahrhunderts v. Chr. Hermes Einzelschrift 63. Stuttgart: Franz Steiner.

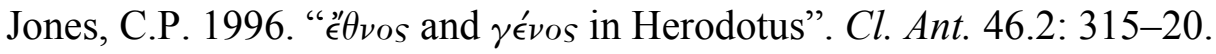

Jones, John Melville. 1986. A Dictionary of Ancient Greek Coins. London: Selby.

Kagan, Donald. 1960. “Pheidon's Aeginetan Coinage”. TPAPhA 91: 121-36.

1982. "The Dates of the Earliest Coins". AJA 86.3: 343-60.

Keen, Antony G. 1996. "Were The Boiotian Poleis Autonomoi?" In Hansen and Raaflaub eds. (1996), 113-25. 
Kirk, G.S. 1985. Iliad: A Commentary, volume I. Cambridge: Cambridge Unviersity Press.

Knoepfler, Denis. 1981. Review of R.J. Buck (1979), A History of Boeotia. Gnomon 53: $140-50$.

Kõiv, Mait. 2011. “A Note on the Dating of Hesiod.” CQ 61.2: 355-77.

Konstan, David. 2001. "To Hellēnikon ethnos: Ethnicity and the Construction of Ancient Greek Identity". In Malkin ed. (2001), 29-50.

Kowalzig, Barbara. 2007. Singing for the Gods: Performances of Myth and Ritual in Archaic and Classical Greece. Oxford: Oxford University Press.

Kraay, Colin. 1976. Archaic and Classical Greek Coins. London: Methuen.

Kroll, John H., and Nancy M. Waggoner. 1984. "Dating the Earliest Coins of Athens, Corinth and Aegina". AJA 88.3: 325-40.

Kurke, Leslie. 1991. The Traffic in Praise: Pindar and the Poetics of Social Economy. Ithaca: Cornell University Press.

Lacroix, Léon. 1958. "Le Bouclier, emblème des Béotiens". Revue belge de philologie et d'histoire 36: 5-30.

Larsen, J. A. O. 1968. Greek Federal States: Their Institutions and History. Oxford: Clarendon Press.

1945. Representative Government in Greek and Roman History. Berkeley: University of California Press.

. 1955. "The Boeotian Confederacy and Fifth-Century Oligarchic Theory". T\&PAPhA 86: 40-50.

1960. "Orchomenus and the Formation of the Boeotian Confederacy in 447 B.C.”. C Phil. 55.1: 9-18.

Larson, Stephanie L. 2000. "Boiotia, Athens, the Peisistratids, and the Odyssey's catalogue of heroines". GRBS 41.3: 193-222.

- 2007. Tales of Epic Ancestry: Boiotian Collective Identity in the Late Archaic and Early Classical periods. Historia Einzelschrift 197. Stuttgart: Steiner.

Lehmann, G.A. 1980. “Der 'Erste Heilige Krieg' - ein Fiktion?” Historia 29: 24246.

Lichtheim, George. 1971. Imperialism. New York: Praeger.

Liddell, H. G., and Scott, R. (1968) A Greek-English Lexicon, ninth edition, revised by Henry Stuart Jones. Oxford: Claredon Press. 
Low, Polly. 2007. Interstate Relations in Classical Greece: Morality and Power. Cambridge: Cambridge University Press.

Ludden, David. 2011. "Process of Empire Frontiers and Borderlands". In Fibiger Bang and Bayly eds. (2011), 132-150.

Macdonald, David. 1987-88. "The Significance of the 'Boiotian League/Chalkis' Silver Issue". Jahrbuch für Numismatik und Geldgeschichte 37/38: 23-29.

Mackil, Emily. 2003. "Koinon and Koinonia: Mechanisms and Structures of Political Collectivity in Classical and Hellenistic Greece". PhD diss., Princeton University.

Mackil, Emily, and Peter G. van Alfen. 2006. "Cooperative Coinage". In Agoranomia: Studies in Money and Exchange Presented to John H. Kroll, edited by Peter G. van Alfen, 201-26. New York: American Numismatic Society.

Malkin, Irad (ed.). 2001. Ancient Perceptions of Greek Ethnicity. Cambridge, MA: Harvard University Press.

Martin, Richard P. 2005. "Pulp Epic: the Catalogue and the Shield". In The Hesiodic Catalogue of Women: Constructions and Reconstructions, edited by Richard Hunter, 153-75. Cambridge \& New York: Cambridge University Press.

McInerney, Jeremy. 2001. "Ethnos and Ethnicity in Early Greece". In Malkin ed. (2001), 51-74.

McKechnie, P.R., and S.J. Kern. 1988. Hellenica Oxyrhynchia. Warminster: Aris \& Philips.

McQueen, E.I. 2000. Herodotus: Book VI. London: Bristol Classical Press.

Meiggs, Russell, and David Lewis. 1989. A Selection of Greek Historical Inscriptions to the end of the fifth century B.C., revised edition. Oxford: Clarendon Press.

Montanari, Franco, Antonios Rengakos and Christos Tsagalis (eds.) 2009. Brill's Companion to Hesiod. Leiden: Brill.

Moretti, Luigi. 1962. Ricerche sulle Leghe Greche (Peloponnesiaca-Beotica-Licia). Rome: L'Erma di Bretschneider.

Morgan, Catherine. 2001. "Ethne, Ethnicity, and Early Greek States, ca. 1200-480 B.C.: An Archaeological Perspective”. In Malkin ed. (2001), 75-112.

- 2003. Early Greek States Beyond the Polis. London: Routledge.

Morris, Ian, and Barry Powell. 2006. The Greeks: History, Culture and Society. Upper Saddle River: Prentice Hall. 
Mossman, J.M. 1995. "Tragedy Epic in Plutarch's Alexander". In Essays on Plutarch's Lives, edited by Barbara Scardigli, 209-28. Oxford: Clarendon Press.

Nagy, Gregory. 1996. Homeric Questions. Austin, TX: University of Texas Press. 2009. "Hesiod and the Ancient Biographical Traditions". In Montanari, Rengakos and Tsagalis eds. (2009), 271-312.

Ostwald, Martin. 1982. Autonomia: Its Genesis and Early History. American Classical Studies 11. Atlanta: American Philological Association Scholars' Press.

Page, Denys Lionel. 1959. History and the Homeric Iliad. Berkeley, CA: University of California Press.

Pavese, C.O. 1998. "The Rhapsodic Epic Poems as Oral and Independent Poems". Harvard Studies in Classical Philology 98: 63-90.

Pelliccia, Hayden. 2009. "Simonides, Pindar and Bacchylides". In Cambridge Companion to Greek Lyric, edited by Felix Budelmann, 240-63. Cambridge: Cambridge University Press.

Pelling, Christopher (ed.) 2010. Plutarch: Rome in Crisis. London and New York: Penguin.

Pelling, Christopher. 2011. Plutarch and History: Eighteen Studies. Swansea: Classical Press of Wales.

Raaflaub, Kurt. 1996. "Born to be Wolves? Origins of Roman Imperialism". In Transitions to Empire: Essays in Greco-Roman History, 360-146 B.C. in honor of E. Badian, edited by Robert W. Wallace and Edward M. Harris. Norman: University of Oklahoma Press.

Ready, Jonathan L. 2007. "Homer, Hesiod, and the Epic Tradition". In The Cambridge Companion to Archaic Greece, edited by H.A. Shapiro, 111-140. Cambridge: Cambridge University Press.

Reynolds, Charles. 1981. Modes of Imperialism. Oxford: Martin Robinson.

Rhodes, P.J., and D.M. Lewis. 1997. The Decrees of the Greek States. Oxford, Clarendon Press.

Robert, L. 1977. "Les fêtes de Dionysos à Thèbes et l'amphictyonie". Archaiologike Ephemeris 1977: 195-210.

Rockwell, Nicholas. 2008. "The Boeotian Army: The Convergence of Warfare, Politics, Society and Culture in the Classical Age of Greece". PhD diss., University of California-Los Angeles.

Roesch, Paul. 1965. Thespies et la Confédération Béotienne. Paris: E. de Boccard. 
1975. "Les Heracleia de Thèbes". ZPE 17: 1-7.

1981. Review of Buck (1979). Phoenix 35.3: 267-71.

Russell, D.A. 1973. Plutarch. London: Duckworth.

Rzepka, Jacek. 2010. "Plutarch on the Theban Uprising of 379 B.C. and the Boiotarchoi of the Boeotian Confederacy Under The Principate". Historia 59.1: 115-18.

Saïd, Edward. 1979. Orientalism. New York: Vintage. 1993. Culture and Imperialism. New York: Knopf.

Salmon, Pierre. 1958. "Les districts béotiens". Revue des Études Anciennes 58: 5170.

1976. Étude sur la Confédération béotienne: Son organisation et son administraton. Brussels: Académie Royale de Belgique.

1985. "Droits et devoirs des cités dans la Confédération béotienne 447/6386). In La Béotie Antique, Lyon - Saint-Étienne, 16-20 mai 1983, edited by Gilbert Argoud and Paul Roesch, 301-6. Paris: Centre National de la Récherche Scientifique.

Schachter, Albert. 1981-94. Cults of Boeotia. BICS Supplement 38, four volumes. London: Institute of Classical Studies.

. 1989. "Boiotia in the Sixth Century B.C." In Beister and Buckler eds. (1989), 65-72.

. 1994. "Gods in the service of the state: the Boiotian experience". In Foresti et al. eds. (1994), 67-85.

- 1996. "Costituzione e sviluppo dell'ethnos beotico". Quaderni Urbinati di Cultura Classica 52.1: 7-29.

Schaps, David M. 2004. The Invention of Coinage and the Monetization of Ancient Greece. Ann Arbor: University of Michigan Press.

Scheidel, Walter. 2011. "Fiscal Regimes and the 'First Great Divergence' between Eastern and Western Eurasia". In Fibiger Bang and Bayly eds. (2011), 193204.

Schumpeter, Joseph. 1919 [1951]. "The Sociology of Imperialisms". In Imperialism and Social Classes, translated by Heinz Norden, 3-101. Cleveland: Meridian Books.

Seltman, Charles. 1955. Greek Coins: A History of Metallic Currency and Coinage down to the Fall of the Hellenistic Kingdoms, second edition. London: Methuen. 
Shrimpton, Gordon S. 1984. "When Did Plataea Join Athens?" C Phil. 79.4: 295304.

Skinner, Marilyn B. 1983. "Corinna of Tanagra and Her Audience". Tulsa Studies in Women's Literature 2.1: 9-20.

Smith, Anthony D. 1986. The Ethnic Origins of Nations. Oxford and New York: Blackwell.

Sordi, Marta. 1951. "I caratteri dell'opera storiografica di Senofonte nelle Elleniche". Athenaeum 1950: 3-53; 1951: 273-348.

. 1993. "La battaglia di Ceresso e la secessioni di Tespie". In Fossey ed. (1993), 25-32.

1994. "Il federalismo Greco nell'età classica". In Foresti et al. eds. (1994), $3-22$.

Ténékidès, George. 1954. La notion juridique d'indépńdance et la tradition hellenique. Athens: Institut Français d'Athènes.

Thompson, Margaret, Otto Mørkholm and Colin Kraay (eds.). 1973. An Inventory of Greek Coin Hoards. New York: American Numismatic Society.

Tuplin, Christopher. 2007. "Continuous Histories (Hellenica)". In A Companion to Greek and Roman Historiography, volume one, edited by John Marincola, 159-70. Malden, MA and Oxford: Blackwell.

Von Reden, Sitta. 2010. Money in Classical Antiquity. Cambridge: Cambridge University Press.

Weber, Max. 2001. "Structures of Power". In Cain and Harrison eds. (2001), 32537.

West, Martin L. 1966. Hesiod: Theogony. Oxford: Clarendon Press.

- 1978. Hesiod: Works \& Days. Oxford: Clarendon Press.

- 1985. Hesiodic Catalogue of Women: Its Nature, Structure and Origins. Oxford: Clarendon Press.

—. 1988. "The Rise of the Greek Epic”. JHS 108: 151-72.

_. 1999. "Frühe Interpolationen in der Ilias". Nachrichten der Academie der Wissenshaften in Göttingen (Phil.-hist. Kl.) 1999.4: 183-91.

- 2001. Studies in the Text and Transmission of the Iliad. Munich and Leipzig: K.G. Saur.

- The Making of the Iliad: Disquisition \& Analytical Commentary. Oxford: Oxford University Press. 
Wight, Martin. 1977. Systems of State. Leicester: Leicester University Press.

Worthington, Ian (ed.). n.d. Brill's New Jacoby. Leiden: Brill. http://referenceworks.brillonline.com/browse/brill-s-new-jacoby.

Zeitlin, Froma I. 1989. "Thebes: Theater of Self and Society in Athenian Drama”. In Nothing to Do With Dionysus? Athenian Drama in Its Social Context, edited by John J. Winkler and Froma I. Zeitlin, 130-167. Princeton, NJ: Princeton University Press. 